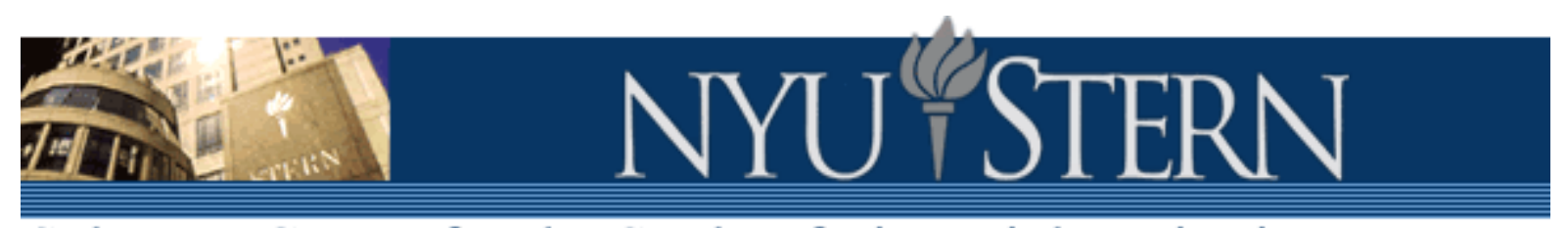

Salomon Center for the Study of Financial Institutions

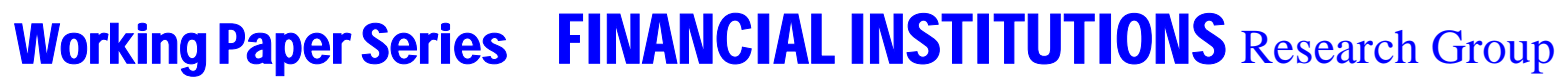

\author{
SO WHAT DO I GET? \\ THE BANK'S VIEW OF LENDING RELATIONSHIPS
}

Sreedhar Bharath

Sandeep Dahiya

Anthony Saunders

Anand Srinivasan

S-FI-04-10 


\title{
So What Do I Get? The Bank's View of Lending Relationships
}

\author{
Sreedhar Bharath, Sandeep Dahiya, Anthony Saunders, and \\ Anand Srinivasan* \\ JEL Classification: G21; G24 \\ Keywords: Lending relationships; Bank loans; Information asymmetry
}

\begin{abstract}
While a number of empirical studies have documented benefits of lending relationships to borrowers (lower loan rates, better credit availability, etc.), not much is known about benefits of such relationships for lenders. For a relationship lender, its comparative advantage in information gathering/processing yields two potential benefits. First, a relationship lender would have a higher probability of selling future information-sensitive products (e.g. loans, security underwriting, etc.) to its borrowers compared to a non-relationship lender. We refer to this as higher volume benefit of relationship lending. Second, if borrower-specific information is only available to relationship lender, it can use this information monopoly to charge higher rates on future loans. We refer to this as increased pricing benefit of relationship lending. Our results show that, on average, a lender with a past relationship with a borrower has a $42 \%$ probability of providing it with future loans, while a lender lacking a past relationship with a borrower has only a $3 \%$ probability of providing it with a future loan. Consistent with theory, we find that borrowers with greater information asymmetries (e.g. small borrowers, or non-rated borrowers) are significantly more likely to use their relationship banks for future loans. Although the association between past lending relationship and probability of being chosen to provide debt and equity underwriting services in the future is statistically significant, the economic impact is much smaller compared to loan markets. However, our findings do not provide strong support for an increased pricing benefit for relationship lenders. On average, the rate of interest for similar borrowers is 6-10 basis points lower if the loan is provided by a relationship lender. Underwriting fee for initial public offerings (IPO) with relationship lender(s) as lead underwriter(s) is 26 basis points lower. This suggests that lenders are prepared to share some of the benefits of relationship lending with borrowers.
\end{abstract}

\footnotetext{
${ }^{*}$ Bharath is with University of Michigan, Dahiya is with Georgetown University, Saunders is with New York University, and Srinivasan is with University of Georgia. Dahiya acknowledges the support of the Lee Higdon, Jr. Faculty Research Fellowship provided by McDonough School of Business. This is a substantially revised version of an earlier paper of the same title. This paper has benefited from suggestions and comments from seminar participants at Federal Reserve Board, University of Michigan, American University, and the Federal Reserve Bank of Chicago's Conference on Bank Structure and Competition. We thank Steven Ongena and Tim Loughran for their helpful comments. Please address all correspondence to Sandeep Dahiya, G-04 Old North, McDonough School of Business, Georgetown University, Washington DC 20057. Tel:(202) 687 3808; Fax:(202) 687 4031. Email: sd@georgetown.edu.
} 


\title{
So What Do I Get? The Bank's View of Lending Relationships
}

\begin{abstract}
While a number of empirical studies have documented benefits of lending relationships to borrowers (lower loan rates, better credit availability, etc.), not much is known about benefits of such relationships for lenders. For a relationship lender, its comparative advantage in information gathering/processing yields two potential benefits. First, a relationship lender would have a higher probability of selling future information-sensitive products (e.g. loans, security underwriting, etc.) to its borrowers compared to a non-relationship lender. We refer to this as higher volume benefit of relationship lending. Second, if borrowerspecific information is only available to relationship lender, it can use this information monopoly to charge higher rates on future loans. We refer to this as increased pricing benefit of relationship lending. Our results show that, on average, a lender with a past relationship with a borrower has a $42 \%$ probability of providing it with future loans, while a lender lacking a past relationship with a borrower has only a $3 \%$ probability of providing it with a future loan. Consistent with theory, we find that borrowers with greater information asymmetries (e.g. small borrowers, or non-rated borrowers) are significantly more likely to use their relationship banks for future loans. Although the association between past lending relationship and probability of being chosen to provide debt and equity underwriting services in the future is statistically significant, the economic impact is much smaller compared to loan markets. However, our findings do not provide strong support for an increased pricing benefit for relationship lenders. On average, the rate of interest for similar borrowers is 6-10 basis points lower if the loan is provided by a relationship lender. Underwriting fee for initial public offerings (IPO) with relationship lender(s) as lead underwriter(s) is 26 basis points lower. This suggests that lenders are prepared to share some of the benefits of relationship lending with borrowers.
\end{abstract}




\section{Introduction}

The special nature of lending relationships has been the subject of extensive theoretical and empirical research in finance. " While there is no precise definition of "relationship banking", scholars broadly agree that if a financial intermediary's decision to supply various services to a firm is based on borrower-specific information that the intermediary collects over multiple interactions (over time as well as across multiple products) and if this information is proprietary (available only to the borrower and the intermediary), the intermediary is engaged in relationship banking (for detailed discussion see Berger (1999) and Boot (2000)). Existing theories predict that establishment of strong lender-borrower relationships can generate significant benefits for the lender. ${ }^{2}$

Empirical evidence on the benefits of banking relationships has largely focused on documenting these benefits to the borrower. This literature can be broadly classified into two distinct approaches. The first approach uses indirect tests to establish the value of banking relationships. Specifically, James (1987) and Lummer and McConnell (1989) find positive stock market reaction to the renewal of lending relationships thus establishing the value-enhancement role of relationships to borrowers. ${ }^{3}$ The second approach attempts to estimate the effects of relationships on borrowers directly by examining the impact that such relationships have on the cost and availability of credit. This approach is best characterized by Petersen and Rajan (1994) and Berger and Udell (1995). They find, among other things, that the stronger (i.e. the longer the duration of) the relationship, the greater is the credit availability and the lower are the collateral requirements.

Our paper differs from the studies cited above in one critical dimension. Our focus is on establishing the existence, and the nature, of the benefits of relationship banking from the

\footnotetext{
${ }^{1}$ See Boot (2000) and Ongena and Smith (1998) for an extensive survey of this literature.

${ }^{2}$ The benefits to a borrower could come from multiple sources such as the ability to share sensitive information (Bhattacharya and Chiesa, (1995)); more flexible contracts compared to public debt (Berlin and Mester (1992), Boot, Greenbuam, and Thakor (1993)); the ability to monitor collateral (Rajan and Winton (1995)); and the ability to smooth out loan pricing over multiple loans (Berlin and Mester (1998)). Another source of benefits for a relationship lender can arise due to potential monopoly power (holdup power) of the lender (e.g. Sharpe (1990) and Rajan (1992)) allowing lender to charge excessive rates for loans to its captive borrowers. Berlin (1996) provides a good overview of these issues of relationship lending.

${ }^{3}$ Further evidence is provided by Slovin, Shushka and Polonchek (1993) and Dahiya, Puri and Saunders (2003) who document a negative impact of the potential termination of lending relationships on the borrower's market value. Ongena, Smith and Michalsen (2003) report similar results for capital constrained Norwegian borrowers when banks of such borrowers faced distress.
} 
perspective of the lender, a subject that has attracted far less attention in the literature. Indeed, relationship studies do not provide any guidance on what are the sources of these benefits to lenders and how the value created by establishing such relationships is shared by lenders and borrowers. ${ }^{4}$ Thus an important question is - what is the value of establishing a lending relationship to a lender (rather than a borrower)?

Existing theories of financial intermediation (see, e.g., Leland and Pyle (1977), Diamond (1984), and Ramakrishnan and Thakor(1984)) emphasize the information production role of banks through screening (Diamond (1991)) and subsequently through monitoring (Rajan and Winton (1995)). Typically, relationship lending involves repeated interaction between a lender and a borrower over time. Such interactions generate "inside information" for the lender and could reduce its cost of providing further loans and other services. ${ }^{5}$ If relationship lending produces reusable and proprietary information about the borrower, a possible benefit for the relationship lender is that it would be better placed to win future loan business and other feegenerating services from its relationship borrower. ${ }^{6}$ While the association between past lending relationships and winning future investment banking business has been examined recently by Drucker and Puri (2004) (for SEOs) and Yasuda (2004) (for public debt underwriting), as far as we are aware, no study has examined the impact of lending relationships on ability to win future loan business. Our paper provides tests that examine whether establishing a lending relationship translates into a higher probability of winning future lending as well as non-lending business for a lender.

The central result of this paper is that strong past lending relationships significantly increase the probability of getting future lending and investment banking business. Holding all else constant, a bank with a prior lending relationship has more than a $40 \%$ probability of winning

\footnotetext{
${ }^{4}$ One study that has attempted to indirectly measure the relationship benefits to the lenders is Dahiya, Saunders and Srinivasan (2003). They find that a bank's share price drops when its borrower announces default. The stock price drop is much greater when the borrower has had an ongoing relationship with the bank, signalling that potential termination of the relationship also results in loss of value to the bank.

${ }^{5}$ Petersen and Rajan (1994) provide a succinct description of this argument: "... if scale economies exist in information production, and information is durable and not easily transferable, these theories suggest that a firm with close ties to financial institutions should have a lower cost of capital ... Implicit, therefore, in our analysis is the assumption that reductions in lender's cost are passed on to the borrower in a lower rate".

${ }^{6}$ Reasons as to why a relationship lender would incur lower information production costs are discussed by Petersen and Rajan (1994). They argue that a relationship lender acquires information about its borrower over time that would be costly for a new lender to acquire, thus giving the relationship lender a cost advantage. Also, if fixed costs of producing information can be spread over multiple products, the marginal cost of providing any individual product would be lower for a relationship lender.
} 
subsequent loan business from its borrower while a bank lacking such a relationship has only a $3 \%$ probability of being chosen to provide future loans. Consistent with theory, borrowers suffering from greater information asymmetry (e.g. small, non-rated firms) are more likely to use their relationship lender for future loans. Moreover, on average, a prior lender is almost twice as likely to be retained as the lead debt underwriter by its (loan) borrowers. While the impact of a prior lending relationship has a limited effect on the choice of an SEO (Seasoned Equity Offering) underwriter, the existence of a past lending relationship is associated with almost a four-fold increase in the probability of being retained as a lead IPO (Initial Public Offering) underwriter by a relationship borrower. To the extent that an increase in future lending and underwriting business is profitable, a greater likelihood of winning future business is a significant benefit to a relationship lender.

Further benefits for a relationship lender arise if it is able to charge higher prices (or economic rents) for loans. This is likely to occur if the borrower is unable to communicate its quality (which is only known to its relationship lender) to other lenders. Rajan (1992) and Sharpe (1990) point out that a relationship lender can exert monopoly power over its borrower and extract rents through higher prices for future loans. However, under certain conditions this rent extraction by a relationship lender may not take place. Sharpe argues banks may invest in building their reputation as "non-exploiting" lenders (to attract future borrowers) by choosing not to charge higher rates to captive borrowers. If the benefits from such reputation building are large enough, relationship banks may not exploit their monopoly power over relationship borrowers. An incumbent bank's monopoly power would also be eroded if borrowers can credibly signal their quality (Sharpe (1990)), if borrowers maintain multiple lending relationships (Rajan (1992)), and/or if the lender is constrained by loan commitments (Houston and Venkataraman (1994)). Thus, the predicted impact of strong relationships on the prices charged on future transactions is ambiguous and is an interesting empirical question that has not been tested extensively. $^{7}$ In this paper, we test if relationship lending is associated with higher prices of future loans and services. Our main results show that relationship loans carry lower costs. While equity underwriting fees are lower for IPOs, fees are not significantly different across relationship and non-relationship borrowers for SEOs. However, fees for debt underwriting are higher for relationship borrowers. These high fees, however, can reflect compensation for

\footnotetext{
${ }^{7}$ For a sample of Belgian firms, Degryse and Van Cayseele (2000) find that while the loan rate increases as the duration of a bank-firm relationship increases (proxy for strengthening of relationship), if the scope of the banking relationship, defined as the purchase of other information-sensitive products from a bank, also increases it results in a significant decrease in the borrower's interest rate.
} 
obtaining better pricing for debt issues (Gande et al. (1997)). Overall, our findings do not suggest pervasive rent extraction by relationship lenders.

The remainder of the paper is organized as follows. We describe our main hypotheses in Section 2. Section 3 describes the data and sample selection process. The methodology and major results are presented in Section 4. We conclude in Section 5.

\section{Theoretical Predictions and Test Hypotheses}

In this section we discuss testable predictions of existing theories of relationship lending and the main hypotheses that we test in this paper. The hypotheses tested in this paper can be broadly classified into two sets; the first set of hypotheses (hypotheses H1, H2 and H3) examine the benefits of relationship lending that accrue from efficiency in information production that a relationship lender enjoys. These hypotheses predict that a relationship lender is more likely to get future business than a non-relationship lender. We refer to these collectively as "higher business volume benefits". The second set of hypotheses (hypotheses H4, and H5) examines whether a relationship lender uses its private information based monopoly power to extract rents from its borrower through higher prices on subsequent loans and financial services. We refer to these collectively as "increased pricing benefits".

As discussed in the introduction, theoretical models view a key source of the benefits arising from strong relationships as those which accrue from economies of scale in information production. If there are fixed costs of information production and if this information is proprietary and reusable, theory suggests that strong relationships would be associated with a lower cost of information production for subsequent lending and service provision decisions (see Greenbaum and Thakor (1995)). A testable implication is that a relationship lender is more likely to capture the future lending business of its borrower. ${ }^{8}$ We formalize this implication in our hypothesis 1 :

Hypothesis 1 (H1) The stronger the bank-borrower relationship, the greater is the probability of a lender attracting future lending business from that borrower.

The choice between bank debt and direct public debt has been the focus of a number of studies. Rajan (1992) defines bank financing as "inside debt" due to a bank's better ability to

\footnotetext{
${ }^{8}$ Tendency to repeat past relationships is well documented in areas other than lender-borrower context. Levinthal and Fichman (1988) report that relationships between auditors and clients were more likely to be renewed as the duration of these relationships increased. Carlton (1986) reports the average duration of buyers and suppliers relationships in the manufacturing industry typically exceeded five years.
} 
collect information about its borrower. Conceptually, relationship lending is repeated extensions of such "informed debt" by the same lender. Public debt, on the other hand, is considered "armslength" financing or "outside debt" where lenders do not engage in proprietary information production. Diamond (1991) argues that borrowers suffering from the most severe information asymmetries (e.g. small firms with less established repayment histories and/or borrowers with poorer credit ratings) have the most to gain from the monitoring provided by banks. Such firms would choose bank financing over public debt financing. Also, Berlin and Mester (1992) suggest that borrowers with poor credit risk would choose bank loans with stringent covenants (because renegotiation of these covenants is easier than that for public debt covenants). These models predict that informationally opaque borrowers would use relationship loans more frequently than borrowers for whom a substantial amount of information is available publicly. This is captured in our hypothesis 2 :

Hypothesis 2 (H2) The more informationally opaque a borrower, the greater the likelihood it will borrow from its relationship lender.

Kanatas and Qi (2003) focus on the benefits of "scope economies" that arise when a single institution offers both lending and underwriting services. These scope economies arise in their model when information costs of learning about their customers in the process of supplying one product, need not be fully incurred again when supplying other products to same customers. ${ }^{9}$ Petersen and Rajan (1994) also discuss the potential benefits to a relationship lender in generating enhanced sales of other non-lending products (e.g. investment banking, deposit-related products, etc.). Such future sales may be a source of value creation since cross-selling multiple products gives the bank the ability to spread the fixed costs of information production over multiple products as well as to generate additional revenues. ${ }^{10}$ This motivates our hypothesis 3 :

Hypothesis 3 (H3) The stronger the bank-borrower relationship, the greater is the probability a lender will attract future investment banking business from that borrower.

While relationship lending has been portrayed as beneficial to both lenders and their borrowers, its cost to borrowers has also received considerable attention. Sharpe (1990) develops a theoretical model where lender-borrower relationships arise simply because the borrowers have

\footnotetext{
${ }^{9}$ Additionally, these benefits can also arise from "purchasing economies of scope" as outlined in Klemperer and Padilla (1997) who argue that borrowers prefer a single source of multiple products to lower their transaction costs.

${ }^{10}$ That is, the potential for cost and revenue economies of scale.
} 
been "informationally captured". High quality borrowers are forced to accept a higher interest rate from their existing lender as it is difficult for them to convey information about their quality to other banks. Similarly, if a borrower's current project succeeds, Rajan (1992) shows that a relationship lender can extract rents from future projects by demanding a high return. This holdup possibility can distort the investment decisions of an entrepreneur. Thus, borrowers who anticipate a sequence of profitable projects (e.g. firms with good future prospects) would prefer arms-length financing or multiple banking relationships. ${ }^{11}$ However, both Sharpe and Rajan discuss conditions that limit or eliminate such rent seeking by a relationship bank. Sharpe argues that if lenders care about their reputation among potential borrowers, they would not charge excessive prices to their relationship borrowers. Rajan contrasts the holdup cost of relationship borrowing against its unique benefit of more flexible contracting that is possible and states “. . . bank debt is easily renegotiated ... any renegotiation [with an arm's length creditor] suffers from information and free-rider problems."

Thus, theory offers conflicting predictions about the impact of lending relationships on prices charged for future loans and service provisions. A relationship lender's ability to acquire private information over the course of a relationship can potentially allow it to use this information to extract (monopoly) rents from its borrower by charging higher rates and fees on future loans and services. To the extent that these "lock-in" effects are present and dominant, such relationships would be associated with a higher cost of relationship loans. However, should the benefits of relationship lending (flexible contracting, lower cost of information gathering, reputation as non-exploitative lender, etc.) outweigh the costs, and, if a lender shares these benefits with its borrower, we should expect relationship loans to carry lower costs. ${ }^{12}$ This is formalized in hypothesis 4:

Hypothesis $4(\mathbf{H 4})$ If a relationship lender exploits its monopoly power, the stronger the bankborrower relationship, the higher is the All-in-Spread Drawn (AISD) ${ }^{13}$ charged on future relationship loans. Alternatively, if the benefits of relationship lending are shared with the borrower,

\footnotetext{
${ }^{11}$ Houston and James (1996) find that borrowers with high future growth opportunities rely less on bank financing if they have a single banking relationship. They argue this is consistent with hold-up problems associated with strong lending relationships.

${ }^{12}$ Lenders may also offer loans as part of a bundle of services where the pricing of each product in the bundle depends on the price of other bundled products. Here the low cost of loans may imply higher costs for other products such as underwriting services.

${ }^{13}$ All-in-Spread Drawn (AISD) measures the interest rate spread on a loan (over LIBOR) plus any associated fees in originating the loan.
} 
a stronger bank-borrower relationship would be associated with a lower All-in-Spread Drawn (AISD) on future loans.

There are conflicting factors that can affect the level of underwriting fees charged by a relationship lender. As discussed above (see hypothesis 3), if scope economies for information production are high, the cost of underwriting securities should be lower for a relationship issuer. To the extent a relationship underwriter shares these cost savings with the issuer, fees for underwriting should be lower for such issues. However, if the relationship lender holds significant monopoly power, the charges for underwriting services need not be lower. Also, a relationship lender can provide credible certification about the quality of the issuer (see Puri (1999)). ${ }^{14}$ If an issuer compensates the relationship lender for providing such certification, the underwriting spreads for issues underwritten by a relationship lender would be higher. This motivates our hypothesis 5 :

Hypothesis 5 (H5) If cost savings in information production are substantial and shared with the issuer, the underwriting spread charged by a relationship lender would be lower. However, if the relationship lender exerts monopoly power and/or is compensated for providing certification of issuer quality, the spreads charged would be higher.

\section{Data and Sample Selection}

To gain insights into these hypotheses we construct a unique database using three primary data sources: The Loan Pricing Corporation Dealscan (henceforth, LPC) database, ${ }^{15}$ a merged CRSP and COMPUSTAT database and the SDC new securities issues database. As described later in the paper, the large number of mergers and acquisitions in the US banking sector over our sample period posed special challenges. To deal with mergers/acquisitions we hand matched data from the SDC mergers and acquisition database, Lexis-Nexis, and the Hoover's corporate histories database to construct a chronology of banking mergers. Since our hypotheses seek to establish directly measurable benefits of relationships to lenders, the estimation of these benefits requires data on the following four different dimensions: data to construct meaningful relationship variables; characteristics of lenders; characteristics of each loan facility; and, characteristics of the borrowers. We discuss each of these four characteristics next in sections 3.1 to 3.4.

\footnotetext{
${ }^{14}$ Puri (1996) and Gande et al. (1997) find that the debt underwritten by prior lenders is sold at higher prices. Schenone (2004) also finds that IPOs underwritten by relationship lenders were valued higher (these issues had lower underpricing). These studies suggest a strong certification role for relationship lenders.

${ }^{15}$ The details of data obtained from LPC database are discussed in the following sections.
} 


\subsection{Construction of Relationship Measures}

One of the primary goals of this paper is to examine the existence and extent of the benefits of relationships to lenders. Thus, it is critical to construct meaningful and measurable proxies for bank relationships as well as their associated benefits. There is no uniformly accepted methodology for measuring the presence and strength of banking relationships. Where the precise point of the start of a banking relationship is available, researchers have often used the length of a relationship as a proxy for its strength (see, for example, Petersen and Rajan (1994) and Berger and Udell, (1995)). Where this information is not available, the existence of a prior lending relationship is used as a proxy (see, for example, Dahiya, Srinivasan and Saunders (2003), Schenone (2004)). All these relationship measures have a potential drawback, which is if an unobservable characteristic (e.g. physical proximity) that causes a borrower and a lender to match-up in the first place continues to be present when the borrower seeks subsequent loans or other banking services. This is a limitation of all relationship measures that are based on the existence and/or intensity of prior interactions between a borrower and its lender. We try to mitigate this drawback by including a physical proximity measure, LOCATION (described later), that controls for locational distance between a borrower and its potential lenders.

To construct the relationship measures, we employed the Loan Pricing Corporation Dealscan (henceforth, LPC) database. This database contains data on loans made to large publicly traded companies. ${ }^{16}$ Our sample period starts in 1986 and ends in March 31, 2001. Since our LPC database coverage started in 1986, our sample period is truncated in the left tail. Thus, a length of relationship measure would be biased since we lack a definitive starting date for any such relationship. Nevertheless, our data set still allows us to construct several other measures that capture the evolution of the bank-borrower relationship over time. We focus on three distinct markets in which a relationship lender can benefit from its close ties with its borrower; the market for bank loans, the market for providing public debt underwriting services, and the market for providing public equity underwriting services. Since we need to take into account the historical relationship at the point in time of a particular transaction, we need to construct these relationship measures for each of the three markets separately. Our methodology for constructing these measures for each of these markets is described next (Appendix A1 provides a summary of all the relationship variables and how they are constructed).

\footnotetext{
${ }^{16}$ The LPC database is increasingly being employed by researchers examining bank loans. See, for example, Carey, Post and Sharpe (1998), Strahan (2000), Dahiya, Saunders and Srinivasan (2003), and Drucker and Puri (2004).
} 


\subsubsection{Market for Bank Loans}

For every loan facility, we construct three alternative measures of relationship strength by looking back and searching the past borrowing record of the borrower. ${ }^{17}$ Thus, for each loan by borrower $i$, we look back over a period of 5 years for any previous loans taken by $i{ }^{18}$ Based on the banks retained for these past loans, we construct various relationship measures as discussed below. For each bank $m$, we construct a lending relationship measure LOANREL $(\mathrm{M})_{m}^{\text {BankLoans }}$, where $\mathrm{M}$ indicates one of the three alternative measures.

The process is best illustrated by an example: In May 1997, Texas Instruments Inc. borrowed $\$ 600$ million from a syndicate led by ABN-AMRO, Citicorp, and Nations Bank. To calculate the strength of ABN-AMRO's relationship at the time of this loan we look back on the borrowing history of Texas Instruments over the 5 years preceding this May 1997 loan. In this window, the following records of borrowing by Texas Instruments appear in the LPC database. On May 1994 Texas Instruments borrowed $\$ 300$ million from a syndicate led by JP Morgan. It borrowed another \$440 million from ABN-AMRO, Citicorp, Fuji Bank and Nations Bank in May 1995. Then in May 1996 it borrowed $\$ 600$ million from ABN-AMRO, Citicorp, Fuji Bank and Nations Bank. Thus, looking back from the point of the May 1997 loan, Texas Instruments contracted loans of $\$ 1340$ million $(300+440+600)$ prior to the May 1997 loan of $\$ 600$ Million. Of the total past borrowing of $\$ 1340, \$ 1040(440+600)$ was provided by ABN-AMRO. In this measure we give full relationship attribution to ABN-AMRO although the loans are syndicated. That is, we attribute $100 \%$ of the loan to every lead bank. This is done as the relationship is established by the granting of the loan rather than the fraction lent by an individual lead bank. Also in most cases, LPC does not provide details on the shares of individual banks in a syndicated loan. Next, we use this example to illustrate the methodology for constructing various relationship measures.

\footnotetext{
${ }^{17}$ We focus on the lead bank(s) on a particular loan facility as the information intensive role being tested in our hypotheses, is most appropriate for the lead bank who typically holds the largest share of a syndicated loan (see Kroszner and Strahan (2001)) and is frequently the administrative agent which has the fiduciary duty to other syndicate members to provide timely information about the borrower. Dennis and Mullineaux (2000) and Madan, Sobhani, and Horowitz (1999) list the functions performed exclusively by the administrative agent; these include monitoring the performance of covenants; relationship management; adminstration of collateral; and loan workouts in case of defaults. Thus the responsibilities of a lead bank best fit the description of a relationship lender.

${ }^{18}$ We chose the 5 year window as approximately $75 \%$ of loan facilities in our sample have maturity less than or equal to 5 years. Thus, most of the borrowers in our sample would need to refinance their debt within 5 years.
} 
The first relationship strength variable is a binary measure designed to pick up the existence of prior lending by the same lender in the past. It is denoted by LOANREL(Dummy) ${ }_{m}^{\text {BankLoans }}$. In this case, for ABN-AMRO, LOANREL(Dummy) BankLoans $_{A B N O A M R O}$ would equal 1 denoting existence of prior lending to Texas Instruments by ABN-AMRO.

The other two measures of relationship strength are continuous. The first continuous measure of relationship strength LOANREL(Amount) $m_{m}^{\text {BankLoans }}$ captures the size of past lending by bank $m$ to borrower $i$. This is calculated as

LOANREL (Amount $)_{m}^{\text {BankLoans }}=\frac{\$ \text { Amount of loans to borrower } i \text { by bank } m \text { in last } 5 \text { years }}{\text { Total } \$ \text { amount of loans by borrower } i \text { in last } 5 \text { years }}$

Thus, in the case of the May 1997 loan to Texas Instruments LOANREL(Amount) for ABN-AMRO would be 0.776 (calculated by dividing $\$ 1040$ by $\$ 1340) .{ }^{19}$

The second continuous measure of relationship strength LOANREL(Number) ${ }_{m}^{\text {BankLoans }}$ captures the frequency of past lending by a bank $m$ to a borrower $i$. It is calculated as LOANREL(Number $)_{m}^{\text {BankLoans }}=\frac{\text { Number of loans to borrower } i \text { by bank } m \text { in last } 5 \text { years }}{\text { Total Number of loans by borrower } i \text { in last } 5 \text { years }}$

Thus, in the case of the May 1997 loan to Texas Instruments LOANREL(Number) BankLoans for ABN-AMRO would be 0.67 (calculated by dividing 2 by 3 ). ${ }^{20}$ The construction of LOAN$\operatorname{REL}(\mathrm{M})_{m}^{\text {BankLoans }}$ is depicted in Figure 1.

\subsubsection{Market for Underwriting Public Debt}

For testing $\mathrm{H} 3$ we focus on two investment banking products that a bank can offer to its relationship borrowers. The first product is underwriting services for public debt issues, and the second product is underwriting services for public equity issues. To examine the impact of a prior lending relationship on winning a public debt underwriting mandate for any bank $m$, we construct a new lending relationship variable LOANREL $(\mathrm{M})_{m}^{\text {PublicDebt }}$ in exactly the same way as LOANREL $(\mathrm{M})_{m}^{\text {BankLoans }}$, the only difference being that for LOANREL $(\mathrm{M})_{m}^{\text {PublicDebt }}$ the date of the look-back period is the date of a public issue of debt while for constructing LOANREL(M ${ }_{m}^{\text {BankLoans }}$ the loan facility activation date was used.

\footnotetext{
${ }^{19}$ Because of the fact that we want to capture relationship strength and because of limited data on syndicate shares we give full attribution to all lending banks.

${ }^{20}$ For this example LOANREL(M) $)_{\text {Citicorp }}^{\text {Bank }}$ and LOANREL $(\mathrm{M}) \underset{\text { Nations Bank }}{\text { BankLans }}$ anould be the same as those calculated for ABN-AMRO as both these banks were also lead banks on the two past loans on which ABNAMRO was the lead bank.
} 
Eccles and Crane (1998) argue that prior investment banking relationships have a significant impact on winning new investment banking business. Thus, we need to control for the existence of such prior investment banking relationships in seeking to identify the independent effect of lending relationships. To better illustrate how we construct prior investment banking relationships, we use the example of firm $i$ that issues public debt for which we wish to calculate the strength of prior investment banking relationships (as described in the next section, the process is the same for an equity issuer). There are two types of investment banking relationship that a bank $m$ can have with the issuer $i$. The first type is the same-market relationship, i.e. for any bank $m$ and a debt issuer $i$, we look for previous debt underwriting relationships that $m$ has had with $i$. The second type is the cross-market relationships, meaning that for a debt issuer $i$ we look to see if $i$ has had a prior equity underwriting relationship with bank $m$. We describe the same market relationship measures first. For any debt issuer $i$, we construct Lead-DEBTREL(M $)_{m}^{\text {PublicDebt }}$ for a bank $m$ in the following way. We take the date of the public issue of debt as the starting point and look back over the preceding 5 years to see if bank $m$ was the "lead-underwriter" to any other public issues of debt by this issuer. Specifically, Lead-DEBTREL(Dummy) ${ }_{m}^{\text {PublicDebt }}$ would equal 1 if $m$ was a lead underwriter on any previous

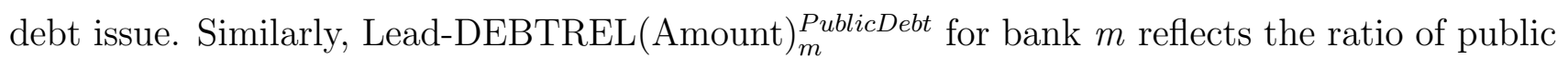
issues of debt underwritten by $m$ (as a lead underwriter) relative to the total number of debt issues of issuer $i$ over the last five years. It is calculated as:

$$
\begin{aligned}
& \text { Lead - DEBTREL }(\text { Amount })_{m}^{\text {PublicDebt }}= \\
& \qquad \frac{\$ \text { Amount of } i \text { 's public debt underwritten by bank } m \text { in last } 5 \text { years }}{\text { Total } \$ \text { amount of public debt issued by } i \text { in last } 5 \text { years }}
\end{aligned}
$$

While Lead-DEBTREL(Number) ${ }_{m}^{\text {PublicDebt }}$ for underwriter $m$ and debt issuer $i$ is calculated as:

$$
\begin{aligned}
& \text { Lead }- \text { DEBTREL }(\text { Number })_{m}^{\text {PublicDebt }}= \\
& \frac{\text { Number of } i \text { 's public debt issues underwritten by bank } m \text { in last } 5 \text { years }}{\text { Total number of public debt issued by } i \text { in last } 5 \text { years }}
\end{aligned}
$$

While we focus on lead underwriters, we also construct expanded versions of Lead-DEBTREL(M $)_{m}^{\text {PublicDebt }}$ variables, denoted by DEBTREL(M $)_{m}^{\text {PublicDebt }}$ in which we include both "leadunderwriting" and "co-manager" roles on prior debt issues.

Next, we describe the cross market relationship measures for a debt issuer $i$. We take the date of the public issue of debt as the starting point and look back over the preceding 5 years to see if bank $m$ was the "lead-underwriter" to any public issues of equity by this issuer. Specifically, Lead-EQUITYREL(Dummy) ${ }_{m}^{\text {PublicDebt }}$ would equal 1 if $m$ was a lead underwriter 
on any previous equity issue. The calculations of Lead-EQUITYREL(Amount) ${ }_{m}^{\text {PublicDebt }}$ and Lead-EQUITYREL(Number) ${ }_{m}^{\text {PublicDebt }}$ are done in the same way. Again, we construct expanded versions of these cross-market relationship measures (denoted by EQUITYREL(M $)_{m}^{\text {PublicDebt) }}$ by including both the lead underwriting and co-manager roles on previous equity issues. The methodology for creating various relationship measures for the public debt underwriting market is illustrated in Figure 2.

\subsubsection{Market for Underwriting Public Equity}

The process for constructing relationship measures for the public equity underwriting market is very similar to the one described in section 3.1.2. We separate our equity issuers into IPO and SEO subsamples as the prior investment banking relationships are not meaningful for the IPO sample since the issuer is conducting its first sale of securities in the public market. ${ }^{21}$ However, both IPO and SEO issuers can have prior lending relationships. Thus we estimate LOANREL(M $)_{m}^{\text {PublicEquity }}$ using the date of public issue of equity as the anchor point for the 5 year look-back window. For SEOs the measure for a same-market investment banking relation-

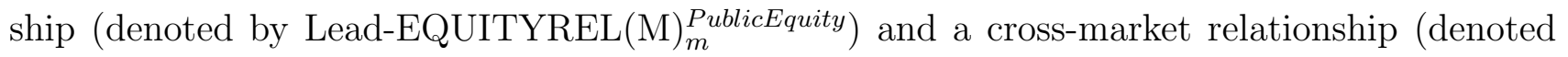
by Lead-DEBTREL(M $)_{m}^{\text {PublicEquity }}$ ) are constructed in a similar fashion. Again we construct expanded versions of Lead-EQUITYREL(M $)_{m}^{\text {PublicEquity }}$ and Lead-DEBTREL $(\mathrm{M})_{m}^{\text {PublicEquity }}{ }^{\text {vari- }}$ ables, denoted by EQUITYREL(M $)_{m}^{\text {PublicEquity }}$ and DEBTREL $(\mathrm{M})_{m}^{\text {PublicEquity in which we include }}$ both "lead-underwriting" and "co-manager" roles on the prior equity and debt issues respectively. Figure 3 illustrates the construction methodology for all of these relationship measures.

The correlations among the various relationship measures are provided in Appendix A2. Within each market our three relationship measures (Dummy, Number and Amount) have a strong positive correlation. Across different markets, however, the relationship measure in one market does not appear to be strongly correlated with relationship measures in other markets.

Table 1 provides descriptive statistics for our data and segregates relationship and nonrelationship loans (i.e. loans from a bank that did not have a past relationship with the borrower in the previous 5 years). Panel A provides the calendar-time distribution of the loan sample. The low number of observations in the early years is driven by two factors. First, the LPC database has had better coverage in more recent years. Second, our methodology for constructing

\footnotetext{
${ }^{21}$ While an IPO firm can not have prior equity underwriting relationships, it may still have prior debt underwriting relationships. However our data showed that firms rarely access the debt market if they do not have a market in their equity. Thus we assume that prior investment banking relationships are not well defined for IPO issuers.
} 
relationship measures ensures that the very first loan reported for any borrower is excluded, otherwise we would not have a historical starting point to classify a loan as either a relationship or a non-relationship loan. To control for this time-trend in the sample we include a calendar year dummy variable in our tests.

We also segregated the samples of public debt issuers and public equity issuers by existence of prior lending relationships. Panel $\mathrm{B}$ and Panel $\mathrm{C}$ of Table 1 provide the calendar time distribution for these issuers.

\subsection{Data on Lender (Bank) Characteristics}

The higher volume benefits to lenders are hypothesized in H1, H2, and H3, to be in the form of the ability to supply future loans and investment banking services to borrower. Thus, relationship benefits to the lender are measured in three complementary ways. First, a strong relationship implies that the likelihood of providing future loans to relationship borrowers would be higher. Second, the probability of winning future debt underwriting from relationship borrowers would be higher. Lastly, the probability of winning future equity underwriting business from relationship borrowers would be higher.

However, the choice of lender (see H1) would also be affected by the potential lender's market share or reputation (all else being equal, a top ranked lender is more likely to be chosen compared to a lower ranked lender), and the loan's characteristics. Similarly the probability of winning investment banking business (see H3) would also depend on the lender's reputation in the relevant investment banking product markets. ${ }^{22}$ Thus, we need data on lender characteristics. Consequently we use the LPC and SDC databases to gather these data.

For the loan market, a key issue is the identification of the "lead" bank (or banks) for a particular loan facility. While the LPC database contains a field that describes the lender's role, it does not have a uniform and consistent methodology to classify which bank is the lead bank. It includes a number of descriptions such as "arranger", " administrative agent", "agent", or "lead manager" that roughly correspond to the lead bank status of the lender. To ensure that we do not mislabel the lead bank we follow a simple rule. Any bank(s) that is (are) not described as a "participant" is (are) treated as a lead bank. ${ }^{23}$. This approach ensures that we do

\footnotetext{
${ }^{22}$ Krigman, Shaw and Womack (2003), show that issuers often switch underwriters to graduate to a more reputable underwriter.

${ }^{23}$ For example Walt Disney Co. contracted a $\$ 1$ billion facility on December 19, 1997. Citicorp and Bank of America with the largest share are listed as Administrative Agents, while all others are listed as Participants. We classify Citicorp and Bank of America as the lead banks on this facility.
} 
not include banks that play a limited information production role. Indeed, Madan et al. (1999) define participant as "the lowest title given to a bank in a syndication" and describe its role as little more than taking the allocated share of the loan.

The borrower's choice of lender bank should also depend on the reputation of the lender and we need to control for this effect. We measure the reputation of a lender by calculating the market share of that lender (market share is a commonly used proxy for reputation, see Megginson and Weiss (1991)). Market share is calculated in the following way; if a bank is a sole lead lender it gets $100 \%$ credit for the loan. If there are $M$ lead banks each gets $(1 / M)^{t h}$ share of the loan. As noted earlier the LPC database rarely gives the precise shares of lead and other banks in a loan syndication. To illustrate by an example, if bank $m$ is the sole lead bank on a loan of $\$ 100$ Million the entire loan amount would be used in calculating its market share, whereas if bank $m$ was one of 4 lead banks, only $\$ 25$ Million ((1/4) th of $\$ 100$ Million) would be included in its market share calculation. ${ }^{24}$ The market share of bank $m$ in any year $t$ as denoted by $(L O A N M K T S H A R E)_{m t}$ is calculated as:

$$
(\text { LOAN MKT SHARE })_{m t}=\frac{(\text { Loan Amount })_{m t}}{\sum_{i=1}^{N}(\text { Loan Amount })_{i t}}
$$

Where (Loan Amount) $m$ is the dollar amount of loans in year $t$ for which the bank $m$ was the lead bank. $N$ is the total number of borrowers in the LPC database. Thus while the numerator captures the lending volume of bank $m$ in year $t$, the denominator is the "total amount of loans" raised (by all borrowers) in year $t$. Panel A of Table 2 provides a list of the top 20 lenders over our entire sample period, ranked by their market share. This table shows that while no single bank dominates the sample, the top 20 banks still account for nearly $70 \%$ of all loans.

To test H3, we focus on the underwriting business in two distinct markets; issues of public debt and issues of public equity. While debt underwriting is related to commercial banks' historical business of corporate lending, e.g. because loan and bond pay-off structures are similar, equity underwriting is a relatively new market for US commercial banks. We use the SDC new issues database to get all the public issues of debt and public issues equity by the borrowers in our sample. This resulted in 5203 distinct issues of debt by 945 firms and 5219 issues of equity by 3129 firms. Next we check if relationship lenders were eligible to underwrite

\footnotetext{
${ }^{24}$ For example Bank of Boston was the sole lender on a June 1997, \$11.9 million facility to GenRad Inc. and thus gets $100 \%$ credit for this deal while it gave a $\$ 350$ million line of credit to Boston Scientific Corp on June 10, 1996 along with Chase Manhattan Bank and Lehman Brothers. For this loan, it was given 1/3 $3^{\text {rd }}$ of the credit while computing market share.
} 
debt (equity) issues at the date of debt (equity) issue. ${ }^{25}$ If none of the relationship lenders, at the date of issue, are eligible to underwrite that issue we exclude that issue from our sample. Our final sample consists of 3923 distinct issues of debt by 721 firms and 1358 issues of equity by 895 firms. For these samples we collect the data on amount raised from the debt (equity) issue, the identity of the lead underwriter(s), and the identity of co-manager(s) of the issue from the SDC database.

The probability of winning the underwriting business in any particular market would depend on the reputation of various players in that market. Again, we use the market share of major underwriters as the proxy for reputation. While the loan market share for each bank is estimated as in equation 5, we use the SDC database's league tables to get the data on market share for major underwriters. Panel B and Panel C of Table 2 provides the list of top-20 underwriters in debt underwriting and equity underwriting respectively and their relative market share. The debt and equity underwriting markets appear to be fairly concentrated, as the top-20 institutions account for over 95 percent of the market.

Finally, in order to control for physical proximity between a bank and a lender (see discussion in section 3.1), we construct a dummy variable LOCATION that equals 1 if both the bank and the borrower have their respective head offices in the same state and 0 otherwise. For lenders the head office location is identified by searching the Hoover's online company history database and for borrowers the head office state is identified from Compustat. For non-US banks we searched for the US headquarters. For a few Japanese banks we were not able to ascertain the exact location of US headquarters and for these we assumed that New York was the US head office (we confirmed that all of these banks did have a New York office). For banks that underwent mergers we used the historical head office for the pre-merger period and the head office of the new merged entity in the post-merger period.

\subsection{Data on Characteristics of Loan Facilities, Debt Issues and Eq- uity Issues}

A primary hypothesis (see H4) we test examines whether strong relationships are associated with the lender's ability to use its information monopoly to extract rents through higher prices

\footnotetext{
${ }^{25}$ At any given date $t$, a commercial bank is assumed to be eligible to underwrite a particular class of security if it has underwritten (either as lead or as co-manager) at least one issue of that class of securities in the period before $t$. We could have also used the regulatory approval date as the start of eligibility but in some cases this date is not available. The requirement of having underwritten at least one deal is thus more conservative and ensures that only active participants are included.
} 
for future loans. To do this we first need to control for various loan characteristics such as maturity, security, type of facility etc. To generate data on loan terms we employed the LPC database. LPC provides data on a facility level as well as a deal level basis. One given deal may correspond to multiple facilities (i.e. multiple loan contracts) of different types of loans to the same firm by one or more banks. Examples of different types of facilities include term loans, lines of credit, revolvers, etc. In this study, we use each facility as the unit of observation. Panel A of Table 3 provides summary statistics on key loan facility terms. Also in H4 we test if a lender charges higher rates and fees on loans to its relationship borrower. The cost of borrowing variable we use is the "All In Spread-Drawn" (AISD), which is the all-inclusive cost of a drawn loan to the borrower. This equals the coupon spread over LIBOR on the drawn amount plus fees. $^{26}$

A lender can also exploit the information "lock-in" effect by charging higher investment banking fees to its relationship borrower (see H5). The most commonly used measure of investment banking fees for securities underwriting is the gross spread. For a specific issue it is calculated by dividing the total fees paid to underwriters by the total proceeds raised from that security issue. ${ }^{27}$ The other key characteristics for the debt and the equity issues are proceeds raised from the issue, date of issuance and identity of lead underwriters and co-managers. Our primary source for all these data is the SDC new issues database. The summary statistics for debt issues is provided in Panels B Table 3. We segregate the public equity issues in Initial Public Offerings (IPOs) and Seasoned Equity Offerings (SEOs) as the fee structure across these two issue classes is different.

\subsection{Data on Borrower Characteristics}

Existing theories argue that informational asymmetries between a borrower and potential debt providers are addressed more effectively by relationship lending than by "arms-length" financing. Borrowers suffering from greater information asymmetries would gain most from relationship lending. Thus, such borrowers are expected to borrow from their relationship lender more frequently (see H2). We use different proxies for information opacity of a borrower such as borrower size, the loan's credit rating, and the tangibility of borrower's assets. COMPUSTAT

\footnotetext{
${ }^{26}$ All In Spread-Drawn is the most commonly used measure of borrowing costs. Recent papers that use this measure include Strahan (2000) and Drucker and Puri (2003).

${ }^{27}$ More precisely, for debt issues it is the ratio of total fees to the principal amount (face value) of debt. However, the proceeds and principal are equal for most cases as most bonds are issued at par. In the paper we use the term "proceeds" for both debt and equity issues for simplicity.
} 
is our primary data source for borrower related variables. The LPC database does not provide a borrower Cusip that can be used as an identifier to match the borrower to other data sets such as the COMPUSTAT or the CRSP. Consequently, we hand match the LPC companies with the merged CRSP/COMPUSTAT database using the name of the company in the LPC database. The matching procedure is conservative in that we assign a match only when we are sure that the company is the same in the two databases. Using this procedure, we are able to obtain a set of 6322 borrowers in the LPC database for which we can obtain the Cusip of the company from the COMPUSTAT database. We then use COMPUSTAT to extract data on accounting variables for the given company. We also extract the primary SIC code for the borrowers from COMPUSTAT and exclude all financial services firms (SIC codes between 6000 and 6999). To ensure that we only use accounting information that is publicly available at the time of a loan we employed the following procedure: for a loan made in calender year $t$, we use fiscal year $t$ data only if the loan activation month is at least 6 months after the fiscal year ending month. Otherwise, we use fiscal year $t-1$ data. $^{28}$ The 6 month minimum gap between fiscal year end and the loan activation date is conservative given the SEC requirement that accounting data be made available within 90 days of fiscal year ending. However, compliance with this requirement is patchy. Fama and French (1992) state "on average $19.8 \%$ percent do not comply (with this requirement)" ${ }^{29}$

\section{Methodology and Empirical Results}

In this section we describe the tests employed to estimate the hypothesized (volume) benefits of relationships to lenders (hypotheses $\mathrm{H} 1, \mathrm{H} 2$, and $\mathrm{H} 3$ ) and of the hypothesized pricing benefits of relationship lending (hypotheses $\mathrm{H} 4$, and $\mathrm{H} 5$ ).

\footnotetext{
${ }^{28}$ The following examples illustrate this methodology. Walmart contracted a $\$ 1.1$ billion loan on October 1 , 1999. Walmart's fiscal year ends on January 31 and thus the October loan is more than 6 months after the month of fiscal year closing. In this case we use the accounting data for fiscal year ending January 31, 1999. On the other hand, Walmart took a $\$ 1.25$ billion loan on May 29, 1995. Since the May loan was less than 6 months after the fiscal year closing we use accounting data for the previous fiscal year, i.e. for the year ending January $31,1994$.

${ }^{29}$ Even for those firms that do comply, a large proportion file on the last allowed day. Alford, Jones, and Zmijeweski, 1992, report that more than 40 \% of firms with a December fiscal year end file on March 31, thus, the data becomes available only in April.
} 


\subsection{Tests of $\mathrm{H1}$}

As discussed in section 2, existing theories of relationship lending predict that strong relationships should be associated with a lower cost of information production over time, provided this information is proprietary and reusable. A testable implication of these theories is that a relationship lender is more likely to get the future lending business of its borrower. We formalize this implication in our hypothesis 1. To test this, for each loan facility, we focus on any bank $m$ 's likelihood of winning the loan business of borrower $i$ at time $t$.

While the number of lenders that appear in our sample is quite large (see Table 2), a handful of banks account for the bulk of lending. To economize on the size of the data set, but still retain most of the large transactions, we chose the following approach. In each year, we kept only those transactions where one of the lead banks was ranked in the top-40 banks by market share in the prior year. Thus, our sample is reduced to those transactions where the lead bank(s) was among the top 40 in the previous year. This allows us to retain $73 \%$ of our original sample as the top 40 banks provide the bulk of all loans. ${ }^{30}$ For each loan we create a choice set of 40 potential lenders, thus creating 40 loan-bank pairs. ${ }^{31}$ Since each loan facility generates a cluster of up to 40 loan-bank pair observations, our data set consists of over 400,000 loan-bank pairs which is the unit of observation in our logit model described below. ${ }^{32}$

$$
\begin{aligned}
(\text { CHOSEN })_{m} & =\beta_{0}+\beta_{1}\left(\text { LOANREL }(M)_{m}^{\text {BankLoans }}\right)+\beta_{2}(\text { LOAN MKT SHARE })_{m} \\
& +\beta_{3}(\text { LOCATION })_{m}+\sum \beta_{k}(\text { CONTROL })_{k} .
\end{aligned}
$$

The variables are discussed below:

- $(\text { CHOSEN })_{m}$ : For each loan facility $i$, we create a dummy variable $(\mathrm{CHOSEN})_{m}$ which takes a value of 1 if a bank $m$ was retained as the lead bank for that loan transaction and 0 otherwise. ${ }^{33}$

\footnotetext{
${ }^{30}$ Even for the $27 \%$ of the original sample that is not used, a large fraction (20\% of the original) was unusable regardless of this requirement because these loans were made in the early years of our sample period and we do not have a long enough history to allow codification of relationship variables. Thus, we only lose $7 \%$ of our sample to the requirement that it must be led by a top-40 bank.

${ }^{31}$ Drucker and Puri (2003) and Ljungqvist, Marston and Wilhelm (2003) use a similar approach to implement their underwriter selection models.

${ }^{32}$ Since observations within each cluster may not be independent we estimate cluster corrected standard errors using the approach suggested by Williams (2000).

${ }^{33}$ Thus, if a bank was the sole lead bank, only the loan-bank pair for this bank would have CHOSEN equal to 1 and for the other 39 CHOSEN would be 0. If the loan facility was led by multiple banks, than all the loan-bank pairs corresponding to these banks would have CHOSEN equal 1 while it would be 0 for the rest.
} 


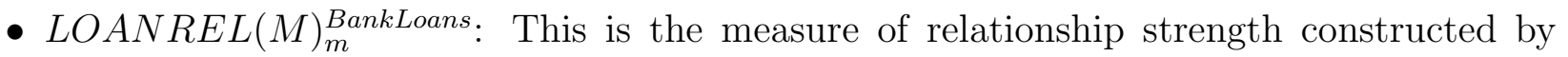
looking back over 5 years from the date of the loan facility activation and searching whether the bank had a prior lending relationship with this borrower. As discussed in section 3.1.1 and Appendix A1, we construct 3 different specifications for this variable to measure the strength of relationship for each of the 40 banks in each loan bank pair.

- (LOAN MKT SHARE $)_{m}$ : To estimate the probability of winning the loan business by a particular bank, we need to control for the reputation of that bank in the loan market. We use its market share as a proxy for reputation. If the loan facility was activated in the year $t$, (LOAN MKT SHARE) $)_{m}$ is the market share of bank $m$ in the prior year, $t-1$, calculated as in equation 5 .

- $(\text { LOCATION })_{m}$ : Dummy variable that equals 1 if bank $m$ and the borrower in a loanbank pair both have their head offices in the same state and 0 otherwise. We include this variable to control for the fact that a borrower may be more likely to give repeat business to a particular bank due to its physical proximity. Since our relationship measure is based on existence and intensity of past interactions, it may be biased by a non-relationship factor such as the proximity of a borrower to a particular lender. Including the LOCATION variable controls for the effect of physical proximity between a borrower and a lender and partially mitigates this possible bias in our relationship measures.

- $(C O N T R O L)_{k}$ : We control for borrower's industry (one digit SIC codes), stated purpose of the loan facility and the year of the loan facility activation by including dummy variables.

A large number of banking mergers and acquisitions took place during our sample period. We assume that in the case of acquisitions the customer relationships of a bank being acquired are inherited by the acquiring bank. ${ }^{34}$ For mergers, the relationships of the merger partners are assumed to be inherited by the new post merger entity. We also adjust the market shares to reflect the M\&A activity. Appendix A3 describes these issues in more detail and also provides an illustrative example.

The results for logit tests of $\mathrm{H} 1$ are reported in Table 4. The coefficient for all specifications of past lending relationships is positive and significant at the one percent level. The panel at the bottom of the Table illustrates the economic significance of past lending relationships on the probability of being chosen to provide future loans. We use the model estimated in column (1) where the past lending relationship is captured simply by existence of (or lack of) prior lending

\footnotetext{
${ }^{34}$ This is one of the objectives of bank mergers and acquisitions.
} 
by the same bank in the last 5 years to calculate these probabilities. The predicted probability of a bank being chosen as the lender for a loan facility if it did not have a past lending relationship $\left(\right.$ i.e. LOANREL $(\text { Dummy })^{\text {BankLoans }}=0$ ) holding all other variables constant at their respective means is $2.73 \%$ (bottom panel, first row). We recalculate the predicted probability keeping all else the same but changing LOANREL(Dummy) $)^{\text {BankLoans }}=1$. The predicted probability of being chosen for a relationship lender rises to $42.46 \% .{ }^{35}$ Thus, holding all else equal, a bank's probability of being chosen to provide a loan is increased by $39.73 \%$ if it had a past lending relationship in the prior 5 years. These results are equally strong if we use continuous measures (specifications in columns 2 and 3) that take into account both the existence and intensity of past lending relationships. For example, changing the LOANREL(Number) ${ }^{\text {BankLoans }}$ measure from its minimum value of 0 to its maximum value of 1 increases the probability of being chosen from $3 \%$ to $77 \%$, while for LOANREL(Amount) BankLoans this probability is predicted to increase from $3 \%$ to $69 \% .^{36}$

It is important to highlight that other variables have a predicted and significant impact on the probability of a bank being retained to provide future loans but their economic impact is smaller compared to the existence of prior lending relationships. As expected, past market share is strongly associated with ability to win a particular loan mandate. The coefficients for LOAN MKT SHARE and LOCATION are positive and significant at the one percent level across all specifications. The bottom panel reports the economic interpretation of these results. As reported in Table 2, the top ranked lender (Citicorp) had approximately a 10\% share of the loan market over our sample period, while the $20^{\text {th }}$ ranked bank (Wachovia) had approximately $1 \%$ market share. To illustrate the impact of a lender's reputation on its probability of being retained we calculate predicted probability by first keeping LOAN MKT SHARE equal to $1 \%$ and then changing it to $10 \%$, while all other variables are kept constant at their respective means. The effect of this is to increase the probability of being chosen from $3 \%$ to $9 \%$. Similar calculations show that the probability of being chosen for a lender that does not have its head office in the same state as the borrower's head office (LOCATION $=0$ ) is $3.54 \%$ and increases to $5.08 \%$ if both lender and borrower are located in the same state (LOCATION $=1)$. Again,

\footnotetext{
${ }^{35} \mathrm{An}$ alternative approach is to interpret the coefficients in terms of increase in odds ratio. Logit model for a binary dependent variable $Y$ can be written in terms of the odds that $Y$ would equal 1 as $\frac{\operatorname{Prob}(Y=1)}{1-\operatorname{Prob}(Y=1)}=e^{\left(\beta^{\prime} x\right)}$. Thus the odds of being chosen as a lender as a function of prior lending relationship

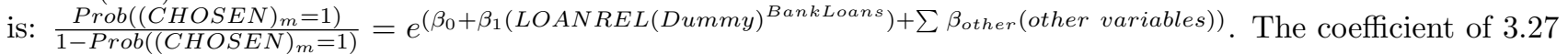
for LOANREL(Dummy) BankLoans implies that the odds of being chosen as the lender is $e^{3.27}$ or approximately 26 times higher if a lender had a prior relationship compared to if it did not have a relationship.

${ }^{36}$ These results are available from the authors on request.
} 
while significant, this is a much smaller economic effect compared to the one associated with having (or not having) a past lending relationship. These results suggest that establishing a lending relationship with a borrower provides significant economic benefits to a lender in terms of a higher probability of getting the future lending business of that borrower.

\subsection{Tests for $\mathrm{H} 2$}

Theoretical models (e.g. Diamond (1991)) predict that relationships are more beneficial for firms that suffer from greater informational asymmetries. This motivates our hypothesis 2 , that informationally opaque firms use relationship lenders more frequently. To test this we use different proxies for information "opaqueness", specifically, the borrower's size and the borrower's credit rating. These are discussed in subsections 4.2.1 and 4.2.2 below.

\subsubsection{The Effect of Borrower Size and H2}

A priori, it is reasonable to argue that smaller sized firms are less likely to be widely followed by either capital market investors (or credit rating agencies). Stein (2002) argues that smallbusiness lending "relies heavily on information that is soft - that is, information that cannot be verified by anyone other than the agent who produces it." This characterization suggests that smaller borrowers would find strong relationships with their lenders particularly beneficial. Smaller firms are also likely to be relatively more informationally opaque, for example, Petersen and Rajan (1994) state: “... there may be large information asymmetries between these [small] firms and potential public investors" ${ }^{37}$ Thus, small firms offer the most potential for proprietary information generation by a relationship lender. If relationships do mitigate the information problems faced by smaller firms, we should expect to find a strong association between the size of a borrower and its use of a relationship bank for future loans.

To examine if relationship lending varies across different borrower sizes, we divide our sample into three size terciles based on the book value of assets of the borrower. Specifically, we add two dummy variables MIDDLE and BIG to equation 6. These variables equal 1 if the borrower

\footnotetext{
${ }^{37} \mathrm{~A}$ number of empirical studies use smaller borrower size as proxy for higher information asymmetries, see for example Blackwell and Kidwell (1988) and Houston and James (1996).
} 
falls in the stated size tercile and 0 otherwise. We also add two interaction terms multiplying the relationship variable with MIDDLE and BIG. The modified logit model is described below:

$$
\begin{aligned}
(\text { CHOSEN })_{m} & =\beta_{0}+\beta_{1}\left(\text { LOANREL }(M)_{m}^{\text {BankLoans }}\right)+\beta_{2}(\text { LOAN MKT SHARE })_{m} \\
& +\beta_{3}(\text { LOCATION })_{m}+\beta_{4}(\text { MIDDLE })+\beta_{5}(\text { BIG }) \\
& +\beta_{6}\left(\text { MIDDLE*LOANREL }(M)_{m}^{\text {BankLoans }}\right) \\
& +\beta_{7}\left(\text { BIG } * \text { LOANREL }(M)_{m}^{\text {BankLoans }}\right)+\sum \beta_{k}\left(C O N T R O L_{k}\right) .
\end{aligned}
$$

The results reported in Table 5, Panel A describe how past lending relationships affect the probability of winning future lending business across different sized borrowers. Since larger borrowers are likely to be informationally more transparent, holding everything else constant we should expect the effect of past relationships on the probability of being chosen as a lender to be the weakest for the large borrowers and largest for small borrowers. The coefficient of LOANREL(Dummy) ${ }_{m}^{\text {BankLoans }}$ is 5.01 if the borrower is in the smallest size tercile, it reduces to 4.13 for the middle tercile and is lowest at 3.71 for the largest tercile, even as it continues to be statistically significant across all borrower size terciles (Table 5, column 1). Thus, the effect of past relationships, while significant, declines as one goes from the smallest borrowers to the largest borrowers. This is also captured in the negative coefficient of the size and relationship interaction terms which are negative and significant at the one percent level across all specifications. In the panel at the bottom of Table 5 we use the specification estimated in column 1 to illustrate the economic significance of past lending relationship benefits across different borrower size terciles. Specifically, we estimate the probability of a bank being chosen as the lead lender if all variables except the relationship variables and the size variables are held equal to their means. The impact of past relationship on the probability of being chosen as lead lender is measured by setting each specific size variable equal to 1 while keeping the other size variables equal to 0 . The first row reports the predicted probabilities (for borrowers in small, medium and large terciles) of a bank being chosen as a lead lender if it did not have a past lending relationship with a borrower LOANREL(Dummy) ${ }_{m}^{\text {BankLoans }}=0$ ) and if all other variables are assumed equal to their means. The next row reports the predicted probability of being chosen if the bank did

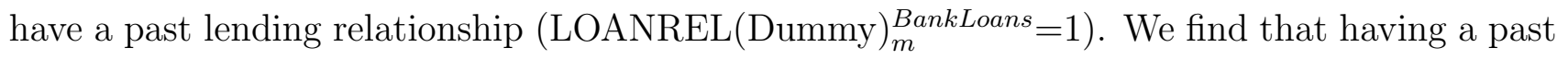
lending relationship increases the probability of being chosen by $63.7 \%$ (from $1.2 \%$ to $64.9 \%$ ) for the borrowers in the smallest tercile. The predicted probability increase for borrowers in the middle and the largest size terciles is $50.5 \%$ (1.7\% to $52.2 \%$ ) and $35.2 \%$ (from $4.1 \%$ to $39.3 \%$ ) respectively. Thus, the probability of a bank being chosen to provide future loans gets smaller as borrower size increases. 


\subsubsection{The Effects of Credit Rating and $\mathrm{H} 2$}

An alternative proxy for informational asymmetries is the availability of a credit rating for the borrower. If the borrower is not rated, a debt-holder needs to generate and process a relatively larger amount of information to make its lending decision. Thus, non-rated borrowers are more likely to turn to their relationship lender for their financing needs relative to public debt markets. For example, Diamond (1991) argues that a borrower's past repayment reputation would drive its choice of borrowing source. A key prediction of his model is that firms with good reputations (i.e. with high credit ratings) would be able to issue (cheaper) public debt, while firms with lower reputations (as evidenced by lower credit ratings) would use bank financing. It is also frequently argued that the information advantages of an insider lender (scale economies in information production, better ability to renegotiate covenants, etc.) would allow it to adopt a more flexible approach towards debt renegotiations. Thus, a relationship bank is expected to "lean against the wind" when its borrowers face financial difficulties. ${ }^{38}$ Consequently, a borrower with a poor credit rating is more likely to use its relationship bank for its borrowing needs. ${ }^{39}$ Below, we employ the existence and level a of credit rating for a borrower as a proxy for the information asymmetries faced by that borrower.

To do this we first partition our sample into firms that have a credit rating and those that do not. We use the credit rating of the loan facility being examined (as reported by LPC) as the most timely measure of the borrower's credit worthiness. It is reasonable to assume that the firms whose loans are not publicly rated, on average, are likely to be less informationally transparent relative to those that have a rating. Thus, we estimate the model:

$$
\begin{aligned}
\left(\text { CHOSEN }_{m}\right. & =\beta_{0}+\beta_{1}\left(\text { LOANREL }(M)_{m}^{\text {BankLoans }}\right)+\beta_{2}(\text { LOAN MKT SHARE })_{m} \\
& +\beta_{3}(\text { LOCATION })_{m}+\beta_{4}(\text { NOT RATED }) \\
& +\beta_{5}\left(\text { NOT RATED } * \text { LOANREL }(M)_{m}^{\text {BankLoans }}\right) \\
& +\sum \beta_{k}\left(\text { CONTROL }_{k}\right) .
\end{aligned}
$$

\footnotetext{
${ }^{38}$ Hoshi, Kashyap and Scharfstein (1990) provide evidence supporting this view. They report that among the financially distressed Japanese firms, those with strong banking relationships were better able to maintain their investment program compared to firms that lacked such banking relationships.

${ }^{39}$ Anecdotal evidence of the limited benefits of relationship lending to best quality borrowers is highlighted in an Economist article dated February $12^{t} h, 1998$, which states: “... Part of $[J P]$ Morgan's problem is that its customers are simply too good. The trouble with serving only the best firms is that they typically like to maintain relationships with at least three banks and play them off against each other to get prices down."
} 
The model in equation 8 includes a dummy variable (NOT RATED), which equals one if the loan is not rated and zero otherwise. We also add an interaction term interacting the relationship variable with NOT RATED to better isolate the effect of the availability of a credit rating on the use of a relationship banker for future borrowing.

For the subsample where the credit rating of the borrower is available, we estimate the following model:

$$
\begin{aligned}
(\text { CHOSEN })_{m} & =\beta_{0}+\beta_{1}\left(\text { LOANREL }(M)_{m}^{\text {BankLoans }}\right)+\beta_{2}(\text { LOAN MKT SHARE })_{m} \\
& +\beta_{3}(\text { LOCATION })_{m}+\beta_{4}(\text { INVESTMENT GRADE }) \\
& +\beta_{5}\left(\text { INVESTMENT GRADE*LOANREL }(M)_{m}^{\text {BankLoans }}\right) \\
& +\sum \beta_{k}\left(\text { CONTROL }_{k}\right) .
\end{aligned}
$$

INVESTMENT GRADE is a dummy variable that equals one if the loan is rated BBB or above by $\mathrm{S} \& \mathrm{P}$ and zero otherwise. We also add an interaction term multiplying the relationship variable with INVESTMENT GRADE to better isolate the effect of credit rating on the use of relationship banker for future borrowing.

The results of equations 8 are reported in Panel B of Table 5. Consistent with our earlier finding, that while the existence of a past relationship increases the probability of winning future loans for all borrowers, this increase is significantly higher for borrowers whose loans have not been rated. Specifically, the coefficient of 3.19 for LOANREL(Amount) ${ }^{\text {BankLoans }}$ if a borrower's loan does not have a rating is higher compared to the coefficient of 2.87 for the borrowers with a rated loan (Table 5, Column 1). The impact of credit ratings is also captured by the positive and significant $(t$-value $=18.7)$ coefficient of the interaction term (multiplying past relationship with the availability of a borrower's credit rating). The economic interpretation of these results is provided in the bottom panel. For a non-rated borrower a relationship lender has a $48 \%$ higher probability ( $50 \%$ vs. $2 \%$ ) of winning future lending business, while for a rated borrower the existence of past relationships increases the predicted probability of being chosen for future loans by $36 \%$ ( $40 \%$ vs. $4 \%$ ). As a result, while the likelihood of being retained for future loans is fairly low for non-relationship lenders to both non-rated $(2 \%)$ and rated borrowers (4\%), the probability of a relationship lender being retained by a non-rated borrower is $10 \%$ higher compared to a rated borrower ( $50 \%$ vs. $40 \%$ ).

Next, we employed the quality of credit rating as a measure of informational transparency of a borrower as in equation 9. Borrowers with an investment grade rating (rated BBB or above by S\&P) are classified as INVESTMENT GRADE. As discussed earlier, theoretical models predict 
high quality borrowers gain relatively less from borrowing from their relationship lender. Thus, we expect the effect of relationships to be weaker for borrowers with a high credit rating. The results reported in Table 5, Panel $\mathrm{C}$ provide some weak support for these predictions. The coefficient on the relationship and investment grade rating interaction term is negative and significant at the one percent level across all specifications ( $t$ - value range of -6.82 to -8.43). Holding all other variables constant at their means, the existence of a past lending relationship is associated with a $38 \%$ increase $(3 \%$ to $41 \%)$ in the probability of being retained for borrowers with loans rated below investment grade. For BBB or above borrowers, past relationships increase the probability of being retained by $34 \%$ ( $5 \%$ to $39 \%$ ).

Taken together our findings in section 4.2 provide strong support for the theoretical predictions underlying H2. That is, informationally opaque firms are more likely to find relationship borrowing beneficial.

\subsection{Tests for H3}

In H3 we hypothesized that if there are scope economies in information production, a relationship lender would have a higher probability of supplying future investment banking/underwriting services (i.e. this is the cross-product marketing motivation behind lending relationships - see, for example, Kantas and Qi (2003)).

\subsubsection{Tests of $\mathrm{H} 3$ and Debt Underwriting}

For our empirical tests, we concentrate on two specific investment banking products that a relationship lender can potentially sell to its existing borrower. The first is the underwriting of public debt issues and the second is the underwriting of public equity issues (IPOs and SEOs).

From the SDC database we derived details of all the debt and equity issues completed by the borrowers in our sample, which had at least one relationship lender eligible to provide the underwriting service (see section 3.2 for our sample selection methodology). For each issue of public debt in year $t$ (in what follows, the process for equity markets is exactly the same) we construct a choice set of top-20 financial institutions (ranked by market share of debt underwriting in the year $t-1$ ). To this set of 20 , we add all the commercial banks (which are not in the top 20 list) that were eligible to underwrite public issues of debt at the date of the debt 
issue. ${ }^{40}$ To test if prior lending relationships are associated with a higher probability of winning an underwriting mandate for issues of public debt, we estimate the following logit model:

$$
\begin{aligned}
(\text { RET AIN })_{m}^{\text {lead-debt }} & =\beta_{0}+\beta_{1}(\text { PROCEEDS })+\beta_{2}\left(\text { LOANREL }(M)_{m}^{\text {PublicDebt }}\right) \\
& +\beta_{3}\left(\text { Lead }- \text { DEBTREL }(M)_{m}^{\text {PublicDebt }}\right) \\
& +\beta_{4}\left(\text { Lead }- \text { EQUITYREL }(M)_{m}^{\text {PublicDebt }}\right) \\
& +\beta_{5}(\text { LOAN MKTSHARE })_{m}+\beta_{6}(\text { TOP TIER }- \text { DEBT })_{m} \\
& +\beta_{7}(\text { MIDTIER }- \text { DEBT })_{m}+\beta_{8}(T O P T I E R-E Q U I T Y)_{m} \\
& +\beta_{9}(\text { MIDTIER }-E Q U I T Y)_{m}+\sum \beta_{k}\left(C O N T R O L_{k}\right) .
\end{aligned}
$$

The variables are discussed below.

- $(R E T A I N)_{m}^{l e a d-d e b t}$ : for each debt issue, we create a dummy variable (RETAIN $)_{m}^{l e a d-d e b t}$ that takes a value of 1 if a bank $m$ was retained as the "Lead Underwriter" for that debt issue transaction and 0 otherwise. ${ }^{41}$

- PROCEEDS: is the dollar amount of proceeds from the debt issue in $\$$ millions.

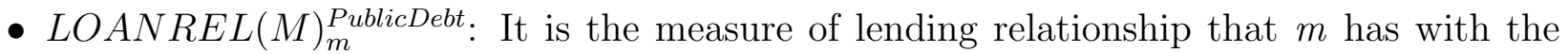
issuer and is constructed in exactly the same way as LOANREL(M $)_{m}^{\text {BankLoans }}$, the only difference being that for $\operatorname{LOANREL}(\mathrm{M})_{m}^{\text {PublicDebt }}$ the date of the look-back period is the date of a public issue of debt while for constructing LOANREL(M ${ }_{m}^{\text {BankLoans }}$ the loan facility activation date was used.

- Lead-DEBTREL $(M)_{m}^{\text {PublicDebt }}$ and Lead-EQUITYREL $(M)_{m}^{\text {PublicDebt }}$ : These are relationship strength measures for debt issue (and equity issue) markets. These measure the intensity of past investment banking relationships of a bank $m$ in debt underwriting and equity underwriting markets respectively. Construction of these variables is described in section 3.1 and Appendix A1.

\footnotetext{
${ }^{40}$ That is if it had underwritten (either as lead or as co-manager) at least one debt issue in the years prior to year $t$.

${ }^{41}$ Thus, if a bank was the sole underwriter, only the issue-bank pair for this bank would have RETAIN equal to 1 and for the other members of the choice set RETAIN would be 0 . If the issue was led by multiple banks, than all the issue-bank pairs corresponding to these banks would have RETAIN equal 1 while it would be 0 for the rest.
} 
- (LOAN MKT SHARE $)_{m}$ for each bank $m$ is calculated for the year prior to the year of debt issue and is calculated as in equation 5 .

- $(\text { TOP TIER }-D E B T)_{m}$ is a dummy variable equal to 1 if the bank $m$ is ranked in the top 5 debt underwriters in the previous year and 0 otherwise.

- (MID TIER - DEBT $)_{m}$ is a dummy variable equal to 1 if the bank $m$ is ranked from $6^{\text {th }}$ to $15^{\text {th }}$ in debt underwriting in the previous year and 0 otherwise.

- (TOP TIER - EQUITY $)_{m}$ is a dummy variable equal to 1 if the bank $m$ is ranked in the top 5 equity underwriters in the previous year and 0 otherwise.

- (MID TIER-EQUITY $)_{m}$ is a dummy variable equal to 1 if the bank $m$ is ranked from $6^{\text {th }}$ to $15^{\text {th }}$ in equity underwriting in the previous year and 0 otherwise.

We do not include the LOCATION variable for underwriter selection models as most of the institutions in the choice set of potential underwriters have a New York City head office.

The results reported in Table 6 provide strong support for H3 in the debt issue underwriting business. The first three columns estimate the effect of a prior lending relationship on the likelihood of winning the lead underwriter role for future debt issues without controlling for existing investment banking relationships. The positive and significant coefficients imply that such lending relationships are associated with an increased probability of winning future debt underwriting mandates. However, the low value of the Pseudo- $\mathrm{R}^{2}$ suggests that the model does not describe the data very well. In columns 4 through 6 we include all the prior investment banking relationship variables and the controls for underwriter reputation both in debt and equity markets (as described in equation 10). The Pseudo- $\mathrm{R}^{2}$ improves from less than 0.02 to more than 0.38. The coefficient for LOANREL(M $)^{\text {PublicDebt }}$ is still positive and significant at the one percent level for all specifications. ${ }^{42}$ Not surprisingly, a prior investment banking relationship in the same market (Lead-DEBTREL(M) ${ }^{\text {PublicDebt }}$ ) is a strong determinant of future debt underwriter selection. The economic significance of prior lending relationships and prior debt underwriting relationships is illustrated in the bottom panel where we use the model specification described in column 4 of Table 6 to explore the impact of prior lending and investment banking relationships. If all variables are held constant at their means and a bank did not have a past lending relationship (LOANREL(Dummy) ${ }^{\text {PublicDebt }}=0$ ) with a debt issuer, its probability of being retained as the lead underwriter of that debt issue is $0.29 \%$. This probability increases

\footnotetext{
${ }^{42}$ These results are similar to those reported by Yasuda (2004) who also finds that past lending relationships have significant impact on winning future debt underwriting mandates.
} 


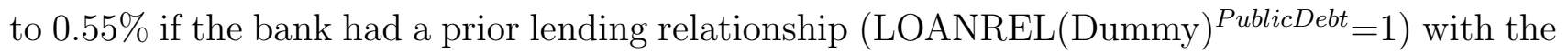
issuer. While a past lending relationship has a statistically significant impact on the probability of being chosen as the future debt underwriter, the economic significance ( $0.55 \%$ probability) is, nevertheless, relatively small. The economic significance of having a past record of providing (underwriting) the same product is larger but still economically small. This is illustrated by the change in probability for a bank with and without a prior debt underwriting with the customer relationship holding all variables constant at their respective means. The existence of a prior debt underwriting relationship increases the probability of winning the lead underwriter role (from $0.28 \%$ for banks with no prior debt underwriting relationship to $2.61 \%$ for banks with prior debt underwriting relationships). Finally, the existence of a past cross-market investment banking relationship (Lead- EQUITYREL ${ }^{\text {PublicDebt }}=1$ ) is associated with an increase in the probability of being retained as lead debt underwriter $(0.31 \%$ to $0.79 \%)$. A prior investmentbanking relationship, even in a different product market (equity underwriting), has a positive relationship with the likelihood of winning future debt-underwriting mandates. Nevertheless, the economic impact of such cross-market relationships are also small.

Overall, compared to the impact of relationships in the market for loans their impact in the debt underwriting market is economically weaker. ${ }^{43}$

\subsubsection{Tests of $\mathrm{H} 3$ and Equity Underwriting}

The second investment banking product we examine is the lead underwriting mandate for issues of public equity. We segregate our sample of public equity issues into Seasoned Equity Offerings (SEOs) and Initial Public Offerings (IPOs). This partitioning also allows us to conduct tests of another aspect of the information production role of relationship lenders. Typically, IPO issuers suffer from a high degree of information asymmetry. Schenone (2004) states "... when firms go public, the market and the firm are asymmetrically informed about true value of the firm." Thus, an underwriter with a strong past lending relationship can provide credible certification about the true value of an IPO issuing firm. Holding all else constant, it is expected that an

\footnotetext{
${ }^{43}$ We also use an alternative underwriting strength definition (RETAIN) ${ }_{m}^{\text {PublicDebt }}$, where this takes the value of 1 if a bank $m$ was retained as either the "Lead Underwriter" or as "Co-Manager" for that debt issue transaction and 0 otherwise. This more inclusive definition addresses the the fact that even a second-tier underwriting role offers incremental revenues for the bank. While the overall results (available on request from the authors) are similar to those in Table 6 , the coefficient for LOANREL $(\mathrm{M})^{\text {PublicDebt }}$ is almost twice as large across all specifications. That is, the prior lending relationship variable now has a much stronger association with the probability of winning a lead-underwriter or a co-manager role.
} 
IPO issuer is more likely to use its relationship lender as its equity underwriter when compared to an SEO issuer. We examine this in more detail below.

For SEOs we estimate the logit model described below:

$$
\begin{aligned}
(\text { RETAIN })_{m}^{\text {lead-SEO }} & =\beta_{0}+\beta_{1}(\text { PROCEEDS })+\beta_{2}\left(\text { LOANREL }(M)_{m}^{\text {PublicEquity }}\right) \\
& +\beta_{3}\left(\text { Lead }- \text { EQUITYREL }(M)_{m}^{\text {PublicEquity }}\right) \\
& +\beta_{4}\left(\text { Lead }- \text { DEBTREL }(M)_{m}^{\text {PublicEquity }}\right) \\
& +\beta_{5}(\text { LOAN MKT SHARE })_{m}+\beta_{6}(\text { TOP TIER }- \text { DEBT })_{m} \\
& +\beta_{7}(\text { MIDTIER }-D E B T)_{m}+\beta_{8}(\text { TOP TIER }-E Q U I T Y)_{m} \\
& +\beta_{9}(\text { MIDTIER }-E Q U I T Y)_{m}+\sum \beta_{k}\left(C O N T R O L_{k}\right) .
\end{aligned}
$$

Since an IPO is the first equity issue by a firm, prior equity underwriting relationships are not meaningful for IPO issuers. Also, since few IPO firms issue public debt prior to their IPO, debt underwriting relationships are not common. Thus, for IPOs we estimate the modified logit model described below.

$$
\begin{aligned}
(\text { RETAIN })_{m}^{\text {Lead-IPO }} & =\beta_{0}+\beta_{1}(\text { PROCEEDS })+\beta_{2}\left(\text { LOANREL }(M)_{m}^{\text {PublicEquity }}\right) \\
& +\beta_{4}(\text { LOAN MKT SHARE })_{m}+\beta_{5}(\text { TOP TIER }-E Q U I T Y)_{m} \\
& +\beta_{6}(\text { MIDDLETIER }-E Q U I T Y)_{m} \\
& +\sum \beta_{k}\left(\text { CONTROL }_{k}\right) .
\end{aligned}
$$

$(\text { RETAIN })_{m}^{S E O}$ is a dummy variable that takes a value of 1 if a bank $m$ was retained as the "Lead Underwriter" for that SEO transaction and 0 otherwise. The results are reported in Table 7 . The first three columns only include lending relationship and loan market reputation variables. As in the tests for the debt underwriting selection model, while the coefficients are significant, the model has a poor fit without the investment banking relationship variables (Pseudo- $\mathrm{R}^{2}$ of 0.01). Columns 4 through 6 report the results for the full model. The coefficient for LOANREL(Dummy) ${ }^{\text {PublicEquity }}$, while positive has low statistical significance, i.e. in one of three specifications it is insignificant and in another it is only significant at the ten percent level. The predicted probability of being retained as a lead SEO underwriter for a bank that did not have a prior lending relationship is $0.30 \%$ (holding all other variables constant at their respective means). This probability essentially remains unchanged at $0.31 \%$ if a bank did have a prior lending relationship (the results are slightly stronger if continuous measures of relationship 
are used with the probability going up from $0.3 \%$ to $0.5 \%$ ). These results suggest that a bank's past lending relationship with a borrower is not associated with that bank's probability of being retained as a lead SEO underwriter by its relationship borrower. ${ }^{44}$

As expected, the results for choice of lead IPO underwriter are different from SEOs. As reported in Table 8, prior lending relationships are associated with a significantly higher probability of winning the lead IPO underwriting role. As can be seen at the bottom of Table 8, a bank that had been a lender in the past had a 3-times higher probability of winning the future IPO underwriting business (rising from $0.48 \%$ to $1.81 \%$ ). However, as with the debt underwriting, the economic impact is much smaller compared to the impact of such relationships on the probability of winning future lending business. ${ }^{45}$

With respect to the other variables in the logit equation, equity underwriting reputation (TOP TIER-EQUITY) translates into a higher probability of being chosen for the equity underwriting role for both SEOs and IPOs. ${ }^{46}$ While the effect of a prior equity underwriting relationship is relevant only for SEOs, similar to the results for debt underwriter selection (Table 6), we find that a prior equity underwriting relationship increases the probability of being retained as lead underwriter of an SEO from $0.3 \%$ to almost $3 \%$.

Although lending relationships do have a positive (but economically small) impact on the probability of generating future investment banking business, overall, the impact of relationships seems to be considerably stronger in the loan market compared to the public debt or equity underwriting markets.

\footnotetext{
${ }^{44} \mathrm{~A}$ possible explanation for these results is that since equity underwriting is somewhat removed from traditional commercial banking business a borrower may feel uncomfortable about rewarding the lead role in SEO underwriting to its relationship lender. However, it can still provide its relationship lender with incremental revenues by including it as a second-tier underwriter by awarding it a "co-manager" role. To test this we use a broader measure of underwriting business (RETAIN) ${ }_{m}^{S E O}$ that equals 1 if bank $m$ gets either the lead underwriter or a co-manager's role. Our results (not reported) show that past lending relationships is significantly associated with ability to win some sort of underwriting role in SEOs (probability of being retained as either lead or co-manager is $1.7 \%$ for a bank lacking past lending relationship and $2.9 \%$ for a relationship lender). However, the economic impact is still small.

${ }^{45}$ When we use a broader measure of underwriting business (RETAIN) ${ }_{m}^{I P O}$ (that equals 1 if bank $m$ gets either the lead underwriter or a co-manager's role), we find (results not reported) significantly higher association between prior lending relationships and probability of winning an underwriter role on the IPOs. For IPOs, a relationship lender has a $13.46 \%$ probability of getting some sort of underwriting role on the IPO equity issue compared to $2.03 \%$ probability for a bank lacking such a relationship.

${ }^{46}$ This is similar to the results of Krigman, Shaw and Womack (2001) who find that issuers often switch underwriters to graduate to more reputable underwriters
} 


\subsection{Tests of $\mathrm{H} 4$}

If strong relationships are associated with "customer relationship rent extraction" by relationship lenders (see H4), the cost of subsequent loans is predicted to be higher - see, for example Greenbaum et al. (1989), Sharpe (1990), and Rajan (1992). However, Boot and Thakor (1994) predict that loan rates would decline as a relationship matures. Hence, there are conflicting predictions as to the level of interest rates (spreads) charged to relationship borrowers.

To examine the impact of lending relationships on loan pricing, we employ a multivariate regression model of the following form:

$$
\begin{aligned}
A I S D & =\beta_{0}+\beta_{1}\left(\text { LOANREL }(M)^{\text {BankLoans }}\right)+\beta_{2}(\text { LOCATION }) \\
& +\sum \beta_{i}(\text { LOAN_CHARACTERSTICS })_{i} \\
& +\sum \beta_{j}(\text { BORROWER_CHARACTERSTICS })_{j} \\
& +\sum \beta_{k}\left(\text { CONTROL }_{k}\right) .
\end{aligned}
$$

The variables in the model are described below.

- AISD: AISD is the "All In Spread-Drawn" (AISD), which equals the coupon spread over LIBOR on the drawn amount plus the annual fee.

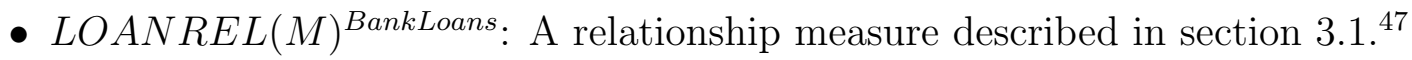

- LOCATION: equals 1 if the head office of the lead bank(s) is located in the same state as the borrower's head office.

- $(\text { LOAN_CHARACTERSTICS })_{i}$ : Various characteristics of loan facility are described below:

- MATURITY: Maturity of loan facility in months

- LN(LOAN SIZE): Natural log of loan facility amount.

- SYNDICATE: A dummy variable that equals 1 if the loan facility was syndicated and 0 otherwise.

- REVOLVER: A dummy variable that equals 1 if the loan facility was a revolver and 0 otherwise.

\footnotetext{
${ }^{47}$ Since this analysis is done at individual loan facility level rather than at each loan-bank pair level, we need a single LOANREL(M) BankLoans value. If the facility has a sole lead lender the LOANREL(M) BankLoans for that bank is used. For loan facilities with multiple lead banks, the LOANREL(M) ${ }^{\text {BankLoans }}$ value of each bank is estimated and the highest value is used.
} 
- TERMLOAN: A dummy variable that equals 1 if the loan facility was a term loan and 0 otherwise.

- (BORROWER_CHARACTERSTICS $)_{j}$ : Various characteristics of the borrower as described below:

- LN(ASSET): Natural log of the book value of the assets of the borrower.

- LEVERAGE: Ratio of book value of total debt to book value of assets.

- COVERAGE: Calculated as natural log of ratio $\left(1+\frac{E B I T D A}{\text { Interest Expenses }}\right)$.

- PROFITABILITY: Ratio of EBITDA to Sales.

- TANGIBILITY: Ratio of Net Property, Plant and Equipment (NPPE) to book value of assets.

- CURRENT RATIO: Ratio of current assets to current liabilities.

- MARKET TO BOOK: Calculated as ratio of (book value of assets - book value of equity + market value of equity) to book value of assets.

- $(C O N T R O L)_{k}$ : These are other control variables and include dummy variables for the year and the reported purpose of the loan facility and the industry of the borrower (SIC codes).

The results for equation 13 are reported in Table 9. Regardless of which measure of relationships is used, the coefficient on the relationship variable is negative and significant at the one percent level. Holding everything else constant, the cost of borrowing from a relationship lender is lower by 4.48 to 9.54 basis points (bps) compared to borrowing from a non-relationship lender. Given that the median AISD is $200 \mathrm{bps}$, existence of a prior relationship implies savings of up to 5 percent of the cost of funds for the borrowers. This suggests that relationship lending is associated with a lower cost of borrowing, consistent with scale economies in generating (proprietary and reusable) borrower specific information and the sharing of these benefits with the borrower. As expected, larger borrower size, high profitability, and higher interest expense coverage of the borrower are all associated with lower interest rates, while high leverage is associated with higher cost of borrowing. ${ }^{48}$

\footnotetext{
${ }^{48}$ Interestingly, if both borrowers and lenders have their head office in the same state, the cost of borrowing is predicted to be higher. These results are similar to those of Degryse and Ongena (2004) who also find that the close proximity of relationship lender is associated with higher loan rates and Petersen and Rajan (2002) who document negative association between predicted lender-borrower distance and the interest rate on the loans.
} 


\subsection{Tests of $\mathrm{H} 5$}

To examine the impact of lending relationship on fees charged for investment banking services, we first focus on issues of public debt. We estimate a model based on Altinkiliç and Hansen $(2000) \cdot{ }^{49}$

$$
\begin{aligned}
& (F E E)^{\text {PublicDebt }}=\beta_{0}+\beta_{1}\left(\text { LOANREL }(M)^{\text {PublicDebt }}\right)+\beta_{2}\left(\text { Lead }- \text { DEBTREL }(M)^{\text {PublicDebt }}\right) \\
& +\beta_{3}\left(\text { Lead }-E Q U I T Y R E L(M)^{\text {PublicDebt }}\right)+\beta_{4}(L O A N \text { MKT SHARE }) \\
& +\beta_{5}(T O P T I E R-D E B T)+\beta_{6}(M I D T I E R-D E B T) \\
& +\beta_{7}(T O P \text { TIER }-E Q U I T Y)+\beta_{8}(M I D T I E R-E Q U I T Y) \\
& +\beta_{9}(1 / P R O C E E D S)+\beta_{10}(P R O C E E D S / M K T C A P) \\
& +\beta_{11}(D E B T V O L U M E)+\sum \beta_{S \& P}(R A T I N G)_{S \& P} \\
& +\sum \beta_{k}\left(\text { CONTROL }_{k}\right) \text {. }
\end{aligned}
$$

Where (FEE) $)^{\text {PublicDebt }}$ is the gross spread calculated as the ratio of fees charged to the total proceeds raised from the debt issue. Since this analysis is conducted at the individual issue level, the explanatory variables are defined slightly differently. For an issue with a sole underwriter no modification is needed and all the variables are the same as those defined earlier in the paper. For an issue that has multiple lead underwriters, the value of a relationship measure in each of the three product markets (i.e. commercial loan, public debt and public equity) is likely to be different across all underwriters. For example, if there are three lead underwriters for a debt issue by borrower $i$, each underwriter may have a different value for LOANREL(M $)^{\text {PublicDebt }}$ depending on its past lending relationship with the issuer $i$ (the values for Lead-DEBTREL(M)PublicDebt and Lead-EQUITYREL(M) ${ }^{\text {PublicDebt }}$ are also likely to be different across all lead-underwriters). In such a case, the highest value of the relationship measure across the underwriters for that issue is assigned to that deal. Similarly, we use the highest value of LOAN MKT SHARE, TOP TIER DEBT and TOP TIER EQUITY among all the underwriters of that issue for this analysis. Finally, we include variables used by Altinkiliç and Hansen (2000) that capture the

\footnotetext{
${ }^{49}$ Altinkiliç and Hansen (2000) find strong evidence that gross spreads for both debt and equity underwriting charged for underwriting have a U-shape. If there are fixed costs for security issuance as well as variable costs that increase with issue size, one should expect such a U-shape. Initially increase in issue size translates into fixed cost being spread over a larger amount thus lowering underwriting spreads as issue size gets larger. However, beyond a certain size the variable costs become large enough and the spreads increase as the issue size gets bigger.
} 
U-shape relationship of underwriting fees to issue amount. PROCEEDS is the amount raised in millions, MKTCAP is the market value of equity of the issuer, DEBTVOLUME is the aggregate value of all debt issued by industrial firms over the the prior three month period as reported by SDC and $($ RATING) $\& \& P$ are dummy variables for S\&P bond rating for the issuer. CONTROL variables include calendar year dummy variables.

The results are reported in Table 10. The coefficient for LOANREL(M $)^{\text {PublicDebt }}$ is positive and significant regardless of the specification used. The coefficient for LOANREL(Dummy) PublicDebt implies that the fees are almost 15 basis points higher if the issuer chooses to have its relationship lender underwrite its debt issue. For the median debt issue size of $\$ 125$ million, the existence of a prior relationship implies that the debt underwriting fees are almost $\$ 187,500$ higher. ${ }^{50}$

The coefficients for Lead-DEBTREL(M) PublicDebt and Lead-EQUITYREL(M) ${ }^{\text {PublicDebt }}$ are positive and insignificant for most specifications. That is, prior investment banking relationships do not appear to have a significant impact on fees charged on subsequent debt underwriting services. However, the reputation of the underwriter does have a significant impact on the fees charged. If a debt issue is underwritten by a top 5 ranked underwriter, the fees are up to 15 basis points lower on average (significant at a $5 \%$ level). ${ }^{51}$

We conduct similar tests focusing on fees (gross spreads) charged for underwriting equity. Our equity underwriting sample includes both initial public offerings (IPOs) and seasoned equity offerings (SEOs). Since underwriting gross spreads for IPOs are typically higher than for SEOs, we estimate the impact of prior relationships on underwriting fees for these two subsamples separately. For SEOs, we estimate the following model (based on Altinkiliç and Hansen (2000)):

\footnotetext{
${ }^{50}$ The association of past relationships with higher debt underwriting fees is also documented by Burch, Nanada and Warther (2004) although their focus is on past investment banking relationships. Using a different data set, Yasuda (2004), finds that fees are lower if debt underwriter has had a prior lending relationship with an issuer. The difference between our results and Yasuda's findings can be due to different time period and different model specification.

${ }^{51}$ We also conducted the same test with an expanded definition of the investment banking relationship. Thus

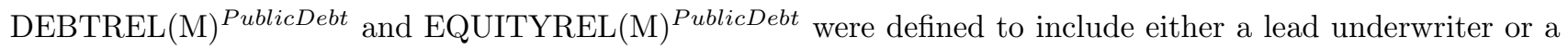
co-manager role. The results were largely unchanged and are not reported in order to conserve space and are available on request from the authors
} 


$$
\begin{aligned}
(F E E)^{S E O} & =\beta_{0}+\beta_{1}\left(\text { LOANREL }(M)_{m}^{\text {BankLoans }}\right)+\beta_{2}\left(\text { Lead }- \text { EQUITYREL }(M)^{\text {PublicEquity }}\right) \\
& +\beta_{3}\left(\text { Lead }- \text { DEBTREL }(M)^{\text {PublicEquity }}\right)+\beta_{4}(\text { LOAN MKT SHARE }) \\
& +\beta_{5}(\text { TOP TIER }- \text { DEBT })+\beta_{6}(\text { MID TIER }- \text { DEBT }) \\
& +\beta_{7}(\text { TOP TIER }-E Q U I T Y)+\beta_{8}(\text { MID TIER }- \text { EQUITY }) \\
& +\beta_{9}(1 / \text { PROCEEDS })+\beta_{10}(\text { PROCEEDS } / \text { MKTCAP }) \\
& +\beta_{11}(\text { EQUITYVOLUME })+\beta_{12}(\text { VOLATILITY })+\sum \beta_{k}(C O N T R O L)_{k} \cdot(15)
\end{aligned}
$$

Most of the variables are the same as those in equation 14. EQUITYVOLUME is the aggregate amount of all equity offerings by industrial firms over the prior three months as reported by SDC. VOLATILITY is the daily standard deviation of the returns on common stock of the issuer and is estimated over the 220 trading day period ending 40 days before the offering date.

Since some of the variables in Altinkiliç and Hansen (2000) model are only applicable for SEOs, i.e. MKTCAP and VOLATILITY, we use a more compact model for IPO underwriting fees:

$$
\begin{aligned}
(F E E)^{I P O} & =\beta_{0}+\beta_{1}\left(\text { LOANREL }(M)^{\text {PublicEquity }}\right)+\beta_{2}(\text { LOAN MKT SHARE }) \\
& +\beta_{3}(\text { TOP TIER }- \text { EQUITY })+\beta_{4}(\text { MID TIER }- \text { EQUITY }) \\
& +\beta_{5}(1 / \text { PROCEEDS })+\beta_{6}(\text { EQUITYVOLUME }) \\
& +\sum \beta_{k}(\text { CONTROL })_{k} .
\end{aligned}
$$

We report our findings in Table 11. Panel A reports the impact of prior lending relationship on the spreads charged for SEOs. The first three columns report the results for a compact model that only includes prior lending relationship variables. The coefficient is negative (ranging from -19.84 basis points to -25.16 basis points) and significant at a $5 \%$ level. ${ }^{52}$

The results for IPOs though are quite different than those for SEOs. As reported in Panel B, the coefficient for LOANREL(M) PublicEquity is negative and significant at the one percent level across all specifications. The fees charged by an underwriter with a past lending relationship

\footnotetext{
${ }^{52}$ However, once we include the prior investment banking relationships, we are reduced to a much smaller sample (884 to 198) and the prior lending relationship variables are no longer significant. Interestingly, prior equity investment banking relationships does not have a statistically significant impact on fees charged for SEO underwriting although the coefficient is negative. Also, the coefficients for equity underwriter's reputation are negative but not significant.
} 
with an issuer is, on average, up to 26 basis points lower $(t$-value $=-2.79)$. Since the median IPO size is $\$ 96$ million, it implies that on average, fees for an IPO issuer are lower by almost $\$ 240,000$ if the equity underwriter is also the relationship lender of the issuer.

\section{Conclusion}

Our paper seeks to measure the direct benefits that a bank-borrower relationship generates for a lender. For lenders, the establishment of a relationship with a borrower allows for more efficient information production/processing in offering future loans and other information sensitive products. Consequently a relationship lender is more likely to get the future business of its borrowers. We find that establishing a relationship with a borrower does indeed increase the likelihood of getting this borrower's future loan business significantly - both statistically and economically. As predicted by theory, the increased likelihood of winning future business is most powerful for borrowers suffering from the greatest degree of informational asymmetry. We also find a statistically strong, although an economically small, association between lending relationships and the probability of winning the future debt and equity underwriting business of the same borrower. Again, consistent with theory, we find that firms conducting IPOs (in contrast to the firms conducting SEOs) are significantly more likely to use their prior lenders as their equity underwriters. We find that the rates charged to similar borrowers are significantly lower for relationship borrowers. While relationship lenders charged higher fees for debt underwriting, the fee charged for IPO underwriting is lower if a relationship lender is the lead underwriter. Overall, these results seem to suggest that relationship lenders pass on some of the benefits of more efficient information processing to their borrowers. 


\section{APPENDIX A1 \\ Methodology for Construction of Relationship Variables}

The table below describes how various measures of relationship are constructed. Panel A describes the methodology for constructing measures that capture existence and extent of prior lending relationship. Panels B and C describe the methodology for constructing prior investment banking relationship measures.

\begin{tabular}{|c|c|}
\hline Relationship Variable & Methodology \\
\hline \multicolumn{2}{|c|}{ Panel A: Lending Relationships-Bank Loan and Investment Banking Markets } \\
\hline \multicolumn{2}{|l|}{ Binary measure } \\
\hline LOANREL(Dummy $)_{m}^{\text {BankLoans }}$ & $\begin{array}{l}\text { Equals } 1 \text { if a bank } m \text { had a prior lending relationship with the firm in at least one } \\
\text { loan during the } 5 \text { years window preceding the date of activation of current loan. }\end{array}$ \\
\hline LOANREL(Dummy $)_{m}^{\text {PublicDebt }}$ & $\begin{array}{l}\text { Same as } L O A N R E L(D u m m y)_{m}^{\text {BankLoans }} \text {, except the look-back window is from the } \\
\text { date of debt issue }\end{array}$ \\
\hline LOANREL(Dummy $)_{m}^{\text {PublicEquity }}$ & $\begin{array}{l}\text { Same as } L O A N R E L(D u m m y)_{m}^{\text {BankLoans }} \text {, except the look-back window is from the } \\
\text { date of equity issue }\end{array}$ \\
\hline \multicolumn{2}{|l|}{ Continuous measure } \\
\hline LOANREL(Amount $)_{m}^{\text {BankLoans }}$ & $\begin{array}{l}\text { Ratio of the dollar value of loans contracted by a firm with the lending bank } m \text { to } \\
\text { the total dollar value of loans contracted by the firm during the } 5 \text { years window } \\
\text { preceding the date of activation of current loan. }\end{array}$ \\
\hline$L O A N R E L(\text { Amount })_{m}^{\text {PublicDebt }}$ & $\begin{array}{l}\text { Same as } L O A N R E L(\text { Amount })_{m}^{\text {BankLoans }} \text {, except the look-back window is from the } \\
\text { date of debt issue for examining the impact of a lending relationship on ability } \\
\text { to attract underwriting of debt issues. }\end{array}$ \\
\hline LOANREL $(\text { Amount })_{m}^{\text {PublicEquity }}$ & $\begin{array}{l}\text { Same as } L O A N R E L(\text { Amount })_{m}^{\text {BankLoans }} \text {, except the look-back window is from the } \\
\text { date of equity issue for examining the impact of a lending relationship on ability } \\
\text { to attract underwriting of equity issues. }\end{array}$ \\
\hline LOANREL $(\text { Number })_{m}^{\text {BankLoans }}$ & $\begin{array}{l}\text { Ratio of the number of loans contracted by a firm with the lending bank } m \text { to the } \\
\text { total number of loans contracted by the firm during the } 5 \text { years window preceding } \\
\text { the date of activation of current loan. }\end{array}$ \\
\hline$L O A N R E L(N u m b e r)_{m}^{P u b l i c D e b t}$ & $\begin{array}{l}\text { Same as } L O A N R E L(N \text { umber })_{m}^{\text {BankLoans }} \text {, except the look-back window is from the } \\
\text { date of debt issue for examining the impact of a lending relationship on ability } \\
\text { to attract underwriting of debt issues. }\end{array}$ \\
\hline LOANREL(Number $)_{m}^{\text {PublicEquity }}$ & $\begin{array}{l}\text { Same as } L O A N R E L(N \text { umber })_{m}^{\text {BankLoans }} \text {, except the look-back window is from the } \\
\text { date of equity issue for examining the impact of a lending relationship on ability } \\
\text { to attract underwriting of equity issues. }\end{array}$ \\
\hline
\end{tabular}




\begin{tabular}{|c|c|}
\hline \multicolumn{2}{|l|}{ Binary measure } \\
\hline Lead-DEBTREL(Dummy $)_{m}^{\text {PublicDebt }}$ & $\begin{array}{l}\text { Equals } 1 \text { if the bank } m \text { had underwritten at least one public debt issue (as } \\
\text { the "Lead-Underwriter") during the } \mathbf{5} \text { years window preceding the current } \\
\text { debt issue. }\end{array}$ \\
\hline Lead - EQUITYREL $(\text { Dummy })_{m}^{\text {PublicDebt }}$ & $\begin{array}{l}\text { Equals } 1 \text { if the bank } m \text { had underwritten at least one public equity issue (as } \\
\text { the "Lead-Underwriter") during the } \mathbf{5} \text { years window preceding the current } \\
\text { debt issue. }\end{array}$ \\
\hline \multicolumn{2}{|l|}{ Continuous measures } \\
\hline Lead-DEBTREL(Amount $)_{m}^{\text {PublicDebt }}$ & $\begin{array}{l}\text { Ratio of the dollar value of public debt issues of a firm underwritten by the } \\
\text { bank } m \text { (as the "Lead-Underwriter") to the total dollar value of public debt } \\
\text { issues by the firm during the } 5 \text { years window preceding the date of current } \\
\text { debt issue. }\end{array}$ \\
\hline Lead - DEBTREL (Number $)_{m}^{\text {PublicDebt }}$ & $\begin{array}{l}\text { Ratio of number of public debt issues of a firm underwritten by the bank } m \\
\text { (as the "Lead-Underwriter") to the total Number of public debt issues by the } \\
\text { firm during the } 5 \text { years window preceding the date of current debt issue. }\end{array}$ \\
\hline Lead - EQUITYREL (Amount $)_{m}^{\text {PublicDebt }}$ & $\begin{array}{l}\text { Ratio of the dollar value of public equity issues of a firm underwritten by the } \\
\text { bank } m \text { (as the "Lead-Underwriter") to the total dollar value of public equity } \\
\text { issues by the firm during the } 5 \text { years window preceding the date of current } \\
\text { debt issue. }\end{array}$ \\
\hline Lead - EQUITYREL(Number $)_{m}^{\text {PublicDebt }}$ & $\begin{array}{l}\text { Ratio of number of public equity issues of a firm underwritten by the bank } \\
m \text { (as the "Lead-Underwriter") to the total Number of public equity issues } \\
\text { by the firm during the } 5 \text { years window preceding the date of current debt } \\
\text { issue. }\end{array}$ \\
\hline \multicolumn{2}{|c|}{ Panel C: Investment Banking Relationships - Equity Underwriting Market } \\
\hline \multicolumn{2}{|l|}{ Binary measure } \\
\hline Lead-EQUITYREL(Dummy $)_{m}^{\text {PublicEquity }}$ & $\begin{array}{l}\text { Equals } 1 \text { if the bank } m \text { had underwritten at least one public equity issue (as } \\
\text { the "Lead-Underwriter") during the } \mathbf{5} \text { years window preceding the current } \\
\text { equity issue. }\end{array}$ \\
\hline Lead - DEBTREL (Dummy $)_{m}^{\text {PublicEquity }}$ & $\begin{array}{l}\text { Equals } 1 \text { if the bank } m \text { had underwritten at least one public debt issue (as } \\
\text { the "Lead-Underwriter") during the } \mathbf{5} \text { years window preceding the current } \\
\text { equity issue. }\end{array}$ \\
\hline \multicolumn{2}{|l|}{ Continuous measures } \\
\hline Lead - EQUITYREL $(\text { Amount })_{m}^{\text {PublicEquity }}$ & $\begin{array}{l}\text { Ratio of the dollar value of public equity issues of a firm underwritten by the } \\
\text { bank } m \text { (as the "Lead-Underwriter") to the total dollar value of public equity } \\
\text { issues by the firm during the } 5 \text { years window preceding the date of current } \\
\text { equity issue. }\end{array}$ \\
\hline Lead - EQUITYREL(Number $)_{m}^{\text {PublicEquity }}$ & $\begin{array}{l}\text { Ratio of number of public equity issues of a firm underwritten by the bank } \\
m \text { (as the "Lead-Underwriter") to the total Number of public equity issues by } \\
\text { the firm during the } 5 \text { years window preceding the date of current equity } \\
\text { issue. }\end{array}$ \\
\hline Lead - DEBTREL(Amount $)_{m}^{\text {PublicEquity }}$ & $\begin{array}{l}\text { Ratio of the dollar value of public debt issues of a firm underwritten by the } \\
\text { bank } m \text { (as the "Lead-Underwriter") to the total dollar value of public debt } \\
\text { issues by the firm during the } 5 \text { years window preceding the date of current } \\
\text { equity issue. }\end{array}$ \\
\hline Lead - DEBTREL (Number $)_{m}^{\text {PublicEquity }}$ & $\begin{array}{l}\text { Ratio of number of public debt issues of a firm underwritten by the bank } m \\
\text { (as the "Lead-Underwriter") to the total Number of public debt issues by the } \\
\text { firm during the } 5 \text { years window preceding the date of current equity issue. }\end{array}$ \\
\hline
\end{tabular}




\section{APPENDIX A2 \\ Descriptive Statistics of Relationship Variables}

The relationship measures are reported on individual loan facility, debt issue transaction and equity issue transaction basis. The bank loan market relationship measure on a particular loan facility is estimated by identifying the lead bank(s) on that facility and then searching over the over the prior 5 years to see if any of the lead bank(s) had been lead banks on any loans during this period. The LOANREL(M) $)^{\text {BankLoans }}$ is thus estimated for all the lead banks on the current facility and the highest value across these is assigned as LOANREL $(M)^{\text {BankLoans }}$ for that loan facility. Similar procedure is followed to estimate the relationship variables for debt and equity issue transactions.

\begin{tabular}{llll}
\hline Panel A: Bank Loan Market - Correlations across different relationship measures & $(2)$ & $(3)$ \\
\hline (1) LOANREL(Dummy) & $(1)$ & & \\
(2) LOnkLoans & 1.00 & 1.00 & 1.00 \\
\hline
\end{tabular}

\begin{tabular}{lllllllll}
\hline \multicolumn{1}{c}{ Panel B: Public Debt Underwriting Market - Correlations across different relationship measures } \\
\hline & $(1)$ & $(2)$ & $(3)$ & $(4)$ & $(5)$ & $(6)$ & $(7)$ & $(8)$ \\
\hline
\end{tabular}

Panel C: Public Equity Underwriting Market - Correlations across different relationship measures

\begin{tabular}{|c|c|c|c|c|c|c|c|c|c|}
\hline & $(1)$ & $(2)$ & (3) & (4) & $(5)$ & (6) & (7) & $(8)$ & (9) \\
\hline (1) Lead -EQUITYREL(Dummy) ${ }^{\text {PublicEquity }}$ & 1.00 & & & & & & & & \\
\hline (2) Lead -EQUITYREL(Number) $)^{\text {PublicEquity }}$ & 0.87 & 1.00 & & & & & & & \\
\hline (3) Lead -EQUITYREL(Amount) $)^{\text {PublicEquity }}$ & 0.89 & 0.98 & 1.00 & & & & & & \\
\hline (4) Lead -DEBTREL(Dummy) PublicEquity & 0.32 & 0.33 & 0.31 & 1.00 & & & & & \\
\hline (5) Lead -DEBTREL(Number) PublicEquity & 0.27 & 0.37 & 0.35 & 0.83 & 1.00 & & & & \\
\hline (6) Lead -DEBTREL(Amount) PublicEquity & 0.29 & 0.37 & 0.35 & 0.86 & 0.99 & 1.00 & & & \\
\hline (7) LOANREL(Dummy) ${ }^{\text {PublicEquity }}$ & 0.16 & 0.19 & 0.18 & 0.13 & 0.11 & 0.10 & 1.00 & & \\
\hline (8) LOANREL(Number) $)^{\text {PublicEquity }}$ & 0.15 & 0.20 & 0.18 & 0.09 & 0.06 & 0.04 & 0.89 & 1.00 & \\
\hline (9) LOANREL(Amount) ${ }^{\text {PublicEquity }}$ & 0.15 & 0.20 & 0.18 & 0.10 & 0.08 & 0.06 & 0.94 & 0.97 & 1.00 \\
\hline
\end{tabular}




\section{APPENDIX A3 \\ Issues Related to Bank M\&A Activity}

The high level of M\&A activity in the US banking industry during our sample period poses two issues that need to be addressed. The first issue is how to account for the relationships of banks that are acquired or merged. We assume that in case of acquisitions all the customer relationships of a bank being acquired are inherited by acquiring bank. For mergers, the relationships of the merger partners are assumed to be inherited by the new post merger entity. The second issue also arises from the significant consolidation of banking industry over our sample period. This affects the identity of the top 40 banks, the calculation of bank market share as well as bank relationships. Several banks that existed in the earlier part of the sample ceased to exist later (due to mergers) or become relatively unimportant in terms of total loan market share in later years. For example, Manufacturers Hanover which was one of the largest commercial banks in the late 1980's merged with Chemical Bank in 1991. Clearly, for loan transactions on or before 1991, Manufacturers Hanover was an important bank that had a chance of securing the lending business. Post 1991, it no longer existed. Thus, it is clear that we need to account for the changing identities of potential lead banks for a given loan over time.

We will use the Chemical-Manufacturers Hanover merger discussed above to illustrate how these methodological issues are addressed. As mentioned before all borrowers that had a lending relationship with either the Old Chemical or the Old Manufacturers Hanover are assumed to be relationship borrowers of the New Chemical Bank. Next issue is what is the historical market share of a new bank resulting from a merger or acquisition if it is the first year of operation for this new entity? We address this in the following way, the historical market share of the new bank is simply imputed from the historical market share of individual banks that merged (or the shares of the target and the acquiror in case of acquisition). Thus 1992 was the first full operating year for the New Chemical Bank resulting from merger between Old Chemical and Old Manufacturers Hanover. Since there is no history for this new bank, the historical market share is calculated by summing the 1991 market shares of Old Chemical and Old Manufacturer's Hanover. A related issue is about the choice set of potential lenders in 1992. For illustrative purposes, assume no other mergers or acquisitions took place in 1991 and that both Old Chemical and Old Manufacturers Hanover were in the top 40 banks in 1991. Using the methodology discussed earlier both these banks would be in the choice set of potential lenders. However neither of these two banks exist in 1992 due to the merger, while the New Chemical is very much a potential provider of loans in 1992. This issue is addressed by assuming as if the New Chemical Bank existed in 1991. This imputed bank would have the market share equal to the sum of two constituents as discussed above. It also implies that the choice set in 1992 would consist of 39 banks instead of 40 as the two merger partners (in this example - Old Chemical and Manufacturers Hanover) are replaced by single merged entity (in this example - the New Chemical Bank). If the merger was between a top 40-bank and a non-top 40 bank no adjustment is done, only the market share needs to be updated and the choice set would still remain 40 . 


\section{References}

[1] Alford, Andrew, Jennifer Jones, and Mark Zmijeweski, 1992, Extensions and Violations of the statutory SEC 10-K filing date, Unpublished manuscript, University of Chicago, Chicago, IL.

[2] Altinkiliç, Oya, and Robert Hansen, 2000, Are there economies of scale in underwriting fees: evidence of rising external financing costs, Review of Financial Studies, 13, 191-218.

[3] Berger, Allen, 1999, The 'Big Picture' of relationship finance, in "Business Access to Capital and Credit" (J. L. Blanton, A.Williams, and S. L. Rhine, Eds.), 390-400.

[4] Berger, Allen, and Gregory Udell, 1995, Relationship lending and lines of credit in small firm finance, Journal of Business, 68, 351-381.

[5] Berlin, Mitchell, 1996, For better and for worse: Three lending relationships, Business Review, Federal Reserve Bank of Philadelphia, November/December, 3-12.

[6] Berlin, Mitchell, and Loretta J. Mester, 1992, Debt covenants and renegotiations, Journal of Financial Intermediation, 2, 95-133.

[7] Berlin, Mitchell, and Loretta J. Mester, 1998, Deposits and relationship lending, Review of Financial Studies, 2, 95-133.

[8] Bhattacharya, Sudipto, and Gabriella Chiesa, 1995, Proprietary information, financial intermediation and research incentives, Journal of Financial Intermediation, 4, 328-357.

[9] Bhattacharya, Sudipto, and Anjan Thakor, 1993, Contemporary banking theory, Journal of Financial Intermediation, 3, 2-50.

[10] Blackwell, David, and David Kidwell, 1988, An investigation of cost differences between public sales and private placements of debt, Journal of Financial Economics, 22, 253-278.

[11] Boot, Arnoud W.A., 2000, Relationship banking: What do we know?, Journal of Financial Intermediation, 9, 7-25.

[12] Boot, Arnoud W.A., Stuart Greenbaum and Anjan Thakor, 1993, Reputation and discretion in financial contracting, American Economic Review, 83, 1165-1183.

[13] Boot, Arnoud W.A., and Anjan Thakor, 1994, Moral hazard and secured lending in an infinitely repeated credit market game, International Economic Review, 35, 899-920. 
[14] Burch, Timothy R., Vikram Nanda, and Vincent A. Warther, 2003, Does it pay to be loyal? An empirical analysis of underwriting relationships and fees, Journal of Financial Economics, Forthcoming.

[15] Carey, Mark, Mitchell Post, and Steven Sharpe, 1998, Does corporate lending by banks and finance companies differ? Evidence on specialization in private debt contracting, Journal of Finance, 53, 845-878.

[16] Carlton, Dennis W., 1986, The rigidity of prices, American Economic Review, 76, 637-58.

[17] Dahiya, Sandeep, Manju Puri, and Anthony Saunders, 2003, Bank Borrowers and Loan Sales: New Evidence on the Uniqueness of Bank Loans, Journal of Business, 76, 563-582.

[18] Dahiya, Sandeep, Anthony Saunders, and Anand Srinivasan, 2003, Financial distress and bank lending relationships, Journal of Finance, 58, 375-399.

[19] Degryse, Hans, and Steven Ongena, 2004, Distance, lending relationships, and competition, Journal of Finance, Forthcoming.

[20] Degryse, Hans, and Patrick Van Cayseele, 2000, Relationship lending within a bank based system: Evidence from European small business data, Journal of Financial Intermediation, 9, 90-109.

[21] Dennis, Steven, and Donald Mullineux, 2000, Syndicated Loans, Journal of Financial Intermediation, 9, 90-109.

[22] Diamond, Douglas, 1984, Financial intermediation and delegated monitoring, Review of Economic Studies, 62, 393-414.

[23] Diamond, Douglas, 1991, Monitoring and reputation: The choice between bank loans and directly placed debt, Journal of Political Economy, 99, 689-721.

[24] Drucker, Steven, and Manju Puri, 2004, Tying of Lending and Equity Underwriting, Journal of Finance, Forthcoming.

[25] Eccles, Robert, and Dwight Crane, 1988, Doing Deals - Investment Banks at Work, Harvard Business School Press, Boston.

[26] Fama, Eugene, and Kenneth French, 1992, Cross-section of expected stock returns, Journal of Finance, 47, 427-465. 
[27] Gande, Amar, Manju Puri, Anthony Saunders, and Ingo Walter, 1997. Bank underwriting of debt securities: Modern evidence, Review of Financial Studies, 10, 1175-1202.

[28] Greenbaum, Stuart, and Thakor, Anjan, 1995, Contemporary Financial Intermediation, Dryden Press, New York.

[29] Hoshi, Takeo, Anil Kashyap, and David Scharfstein, 1990, The role of banks in reducing the costs of financial distress in Japan, Journal of Financial Economics, 27, 67-88.

[30] Houston, Joel, and James, Christopher, 1996, Bank information monopolies and the mix of private and public debt claims, Journal of Finance, 51, 1863-1889.

[31] Houston, Joel, and Subu, Venkataraman, 1994, Information revelation, lock-in, and bank loan commitments, Journal of Financial Intermediation, 3, 355-378.

[32] James, Christopher, 1987, Some evidence of the uniqueness of bank loans, Journal of Financial Economics, 19, 217-235.

[33] Kanatas, George, and Jianping Qi, 2003, Integration of lending and underwriting: Implications of scope economy, Journal of Finance, 58, 1167-1191.

[34] Klemperer, Paul, and A. Jorge Padilla, 1997, Do firms' product lines include too many variables, RAND Journal of Economics, 28, 472-488.

[35] Krigman, Laurie, Wayne H. Shaw, and Kent L. Womack, 2001, Why do firms switch underwriters?, Journal of Financial Economics, 60, 245-284.

[36] Kroszner, Randall S., and Phillip Strahan, 2001, Throwing good money after bad? Board connections and conflicts in bank lending, NBER Working Paper No. 8694.

[37] Leland, Hayne, and David, Pyle, 1977, Informational asymmetries, financial structure and financial intermediation, Journal of Finance, 32, 371-87.

[38] Levinthal, Daniel, and Mark Fichman, 1988, Dynamics of interorganizational attachments: Auditor-client relationships, Administrative Science Quarterly, 33, 345-69.

[39] Ljungqvist, Alexander, Felicia Marston, and William J. Wilhelm, 2003, Competing for securities underwriting mandates: banking relationships and analysts recommendations, Mimeo, New York University. 
[40] Lummer, Scott, and John McConnell, 1989, Further evidence on the bank lending process and the reaction of the capital markets to bank loan agreements, Journal of Financial Economics, 25, 99-122.

[41] Madan, Ruchi, Robert Sobhani, and Keith Horowitz, 1999, Syndicated Lending, PianeWebber Equity Research Report.

[42] Megginson, William, and Kathleen Weiss, 1991, Venture capitalist certification in initial public offerings, Journal of Finance, 46, 879-903.

[43] Ongena, Steven, and David Smith, 1998, Banking relationships: A review, in "The performance of financial institutions" (P. Harker, and S. A. Zenios, Eds.) Cambridge University Press, Cambridge, UK.

[44] Ongena, Steven and David Smith, 2001, The duration of bank relationships, Journal of Financial Economics, 61, 449-475.

[45] Ongena, Steven, David Smith, and Dag Michalsen, 2003, Firms and their distressed banks: lessons from the Norwegian banking crisis, Journal of Financial Economics, 67, 81-112.

[46] Petersen, Mitchell A., and Raghuram G. Rajan, 1994, The benefits of lending relationships: Evidence from small business data, Journal of Finance, 49, 3-37.

[47] Petersen, Mitchell A., and Raghuram G. Rajan, 2002, Does distance still matter? The information revolution in small business lending, Journal of Finance, 57, 2533- 2570.

[48] Puri, Manju 1996, Commercial banks in investment banking conflict of interest or certification role?, Journal of Financial Economics, 40, 373-401.

[49] Puri, Manju 1999, Commercial banks as underwriters: implications for the going public process, Journal of Financial Economics, 54, 133-163.

[50] Rajan, Raghuram G., 1992, Insiders and outsiders: The relationship between relationship and arms length debt, Journal of Finance, 47, 1367-1400.

[51] Rajan, Raghuram G., and Andrew Winton, 1995, Covenants and collateral as incentives to monitor, Journal of Finance, 50,1113-1146.

[52] Ramakrishnan, Ram and Anjan Thakor, 1984, Information reliability and a theory of financial intermediation, Review of Economic Studies, 51, 415-432. 
[53] Schenone, Carola, 2004, The effect of banking relations on the firm's IPO underpricing, Journal of Finance, Forthcoming.

[54] Sharpe, Steven, 1990, Asymmetric information, bank lending and implicit contracts: A stylized model of customer relationship, Journal of Finance 45, 1069-1087.

[55] Slovin, Myron B., Marie A. Shuska, and John A. Polonchek, 1993, The value of bank durability: Borrowers as the bank stakeholders, Journal of Finance, 48, 247-266.

[56] Stein, Jeremy C., 2002, Information production and capital allocation: Decentralized vs. hierarchical firms, Journal of Finance, 57, 1891-1921.

[57] Strahan, Phillip, 1999, Borrower risk and the price and nonprice terms of bank loans, Federal Reserve Bank of New York, Staff Paper No. 90.

[58] Yasuda, Ayako, 2004, Do bank relationships affect the firm's underwriter choice in the corporate-bond underwriting market?, Journal of Finance, Forthcoming.

[59] Williams, Rick L., 2000, A note on robust variance estimation for cluster-correlated data, Biometrics, 56, 645-646. 


\section{TABLE 1}

\section{Calendar Time Distribution of Loan Facilities, Public Debt Issues and Public Equity Issues}

Panel A below provides the calendar time distribution for the sample of loan facilities, broken in to loans for which none of the

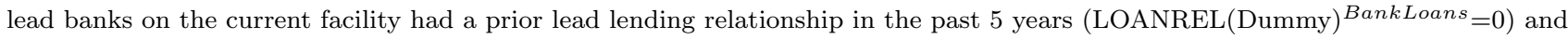
those for which at least one of the lead banks on the current facility was also the lead lender in the prior 5 years (LOANREL$\left(\right.$ Dummy) ${ }^{\text {BankLoans }}=1$ ). Panel B provides similar data for public debt issues segregated by LOANREL(Dummy) ${ }^{\text {PublicDebt }}$ (i.e. if one of the lead underwriter had a lead lending relationship in 5 years prior to current debt issue). Panel C provides similar data for public equity issues segregated by LOANREL(Dummy) PublicEquity (i.e. if one of the lead underwriter had a lead lending relationship in 5 years prior to current equity issue).

\begin{tabular}{|c|c|c|c|}
\hline \multicolumn{4}{|c|}{ Panel A :Calendar Time Distribution of Loans } \\
\hline Year of Loan & No Relationship & Relationship & Total \\
\hline Sanction & LOANREL(Dummy) $)^{\text {BankLoans }}=0$ & LOANREL(Dummy) $)^{\text {BankLoans }}=1$ & \\
\hline 1986 & 1 & 2 & 3 \\
\hline 1987 & 67 & 33 & 100 \\
\hline 1988 & 222 & 174 & 396 \\
\hline 1989 & 237 & 240 & 477 \\
\hline 1990 & 212 & 329 & 541 \\
\hline 1991 & 222 & 366 & 588 \\
\hline 1992 & 373 & 491 & 864 \\
\hline 1993 & 404 & 714 & 1,118 \\
\hline 1994 & 398 & 961 & 1,359 \\
\hline 1995 & 311 & 1,070 & 1,381 \\
\hline 1996 & 488 & 1,207 & 1,695 \\
\hline 1997 & 543 & 1,551 & 2,094 \\
\hline 1998 & 523 & 1,384 & 1,907 \\
\hline 1999 & 434 & 1,293 & 1,727 \\
\hline 2000 & 348 & 1,530 & 1,878 \\
\hline 2001Q1 & 106 & 464 & 570 \\
\hline Total & 4,889 & 11,809 & 16,698 \\
\hline
\end{tabular}


TABLE 1 (continued)

\begin{tabular}{|c|c|c|c|}
\hline \multicolumn{4}{|c|}{ Panel B :Calendar Time Distribution of Public Debt Issues } \\
\hline Year of Public & No Relationship & Relationship & Total \\
\hline Debt Issue & LOANREL(Dummy) $)^{\text {PublicDebt }}=0$ & LOANREL(Dummy) $)^{\text {PublicDebt }}=1$ & \\
\hline 1989 & 48 & 1 & 49 \\
\hline 1990 & 71 & 1 & 72 \\
\hline 1991 & 98 & 14 & 112 \\
\hline 1992 & 197 & 44 & 241 \\
\hline 1993 & 187 & 72 & 259 \\
\hline 1994 & 119 & 64 & 183 \\
\hline 1995 & 182 & 109 & 291 \\
\hline 1996 & 240 & 171 & 411 \\
\hline 1997 & 349 & 191 & 540 \\
\hline 1998 & 341 & 283 & 624 \\
\hline 1999 & 139 & 248 & 387 \\
\hline 2000 & 129 & 178 & 307 \\
\hline 2001 & 92 & 259 & 351 \\
\hline Total & 2192 & 1635 & 3827 \\
\hline \multicolumn{4}{|c|}{ Panel C :Calendar Time Distribution of Public Equity Issues } \\
\hline Year of Public & No Relationship & Relationship & Total \\
\hline Equity Issue & LOANREL(Dummy) $)^{\text {PublicEquity }}=0$ & LOANREL(Dummy) $)^{\text {PublicEquity }}=1$ & \\
\hline 1989 & 1 & 0 & 1 \\
\hline 1990 & 1 & 0 & 1 \\
\hline 1991 & 24 & 0 & 24 \\
\hline 1992 & 45 & 2 & 47 \\
\hline 1993 & 70 & 13 & 83 \\
\hline 1994 & 43 & 10 & 53 \\
\hline 1995 & 58 & 10 & 68 \\
\hline 1996 & 147 & 30 & 177 \\
\hline 1997 & 154 & 31 & 185 \\
\hline 1998 & 125 & 47 & 172 \\
\hline 1999 & 128 & 80 & 208 \\
\hline 2000 & 94 & 68 & 162 \\
\hline 2001 & 85 & 64 & 149 \\
\hline Total & 975 & 355 & 1330 \\
\hline
\end{tabular}


TABLE 2

\section{Market Share Ranking of Major Lenders, Debt Underwriters, and Equity Underwriters}

Panel A describes the top 20 lenders for sample period based on data from LPC dealscan database. Panel B and Panel C describe the top 20 debt and equity underwriters as reported by SDC new issues database.

\begin{tabular}{|c|c|c|c|c|}
\hline \multicolumn{5}{|c|}{ Panel A: Top - 20 Lenders } \\
\hline \multirow[t]{2}{*}{ Rank } & \multirow[t]{2}{*}{ Bank } & \multirow{2}{*}{$\begin{array}{l}\text { Number } \\
\text { of Deals }\end{array}$} & \multirow{2}{*}{$\begin{array}{r}\text { Market } \\
\text { share }\end{array}$} & \multirow{2}{*}{$\begin{array}{r}\text { Amount } \\
(\$ \text { Million) }\end{array}$} \\
\hline & & & & \\
\hline 1 & CITICORP & 2622 & $9.72 \%$ & 429,162 \\
\hline 2 & BANK-AMERICA & 4257 & $9.44 \%$ & 416,913 \\
\hline 3 & CHASE & 3102 & $7.84 \%$ & 346,470 \\
\hline 4 & J-P-MORGAN & 1347 & $5.76 \%$ & 254,320 \\
\hline 5 & CHEMICAL & 1457 & $5.09 \%$ & 224,738 \\
\hline 6 & NATIONS-BANK & 2660 & $4.54 \%$ & 200,338 \\
\hline 7 & FIRST-CHICAGO & 1298 & $3.04 \%$ & 134,310 \\
\hline 8 & BANKERS-TRUST & 1217 & $2.72 \%$ & 120,261 \\
\hline 9 & BANK-NOVA-SCOTIA & 1594 & $2.58 \%$ & 113,954 \\
\hline 10 & BANK-ONE & 1477 & $2.31 \%$ & 101,901 \\
\hline 11 & BANK-NEW-YORK & 1300 & $2.14 \%$ & 94,328 \\
\hline 12 & FIRST-UNION & 1556 & $2.06 \%$ & 90,885 \\
\hline 13 & ABN-AMRO & 1054 & $1.85 \%$ & 81,868 \\
\hline 14 & DEUTSCHE-BANK & 767 & $1.75 \%$ & 77,314 \\
\hline 15 & TORONTO-DOMINION-BANK & 886 & $1.66 \%$ & 73,362 \\
\hline 16 & CIBC & 1059 & $1.59 \%$ & 70,022 \\
\hline 17 & BANK-BOSTON & 1296 & $1.44 \%$ & 63,541 \\
\hline 18 & CREDIT-LYONNAIS & 989 & $1.38 \%$ & 60,857 \\
\hline 19 & SOC-GEN & 665 & $1.20 \%$ & 53,208 \\
\hline \multirow[t]{2}{*}{20} & WACHOVIA & 671 & $1.20 \%$ & 53,207 \\
\hline & Overall & 24,174 & $69.29 \%$ & $4,417,304$ \\
\hline
\end{tabular}


TABLE 2(CONTINUED)

\begin{tabular}{|c|c|c|c|c|}
\hline \multicolumn{5}{|c|}{ Panel B: Top- 20 Debt Underwriters } \\
\hline Rank & Bank & $\begin{array}{l}\text { Number } \\
\text { of Deals }\end{array}$ & $\begin{array}{r}\text { Market } \\
\text { share }\end{array}$ & $\begin{array}{r}\text { Amount } \\
\text { (\$ Million) } \\
\end{array}$ \\
\hline 1 & GOLDMAN-SACHS & 640 & $16.03 \%$ & 119,331 \\
\hline 2 & MERRILL & 634 & $14.56 \%$ & 108,386 \\
\hline 3 & MORGAN-STANLEY & 498 & $11.38 \%$ & 84,737 \\
\hline 4 & CITICORP & 319 & $9.95 \%$ & 74,119 \\
\hline 5 & CSFB & 371 & $9.49 \%$ & 70,660 \\
\hline 6 & LEHMAN & 339 & $8.81 \%$ & 65,588 \\
\hline 7 & SALOMON & 310 & $5.63 \%$ & 41,895 \\
\hline 8 & J-P-MORGAN & 303 & $5.28 \%$ & 39,341 \\
\hline 9 & BANK-AMERICA & 159 & $4.06 \%$ & 30,236 \\
\hline 10 & BEAR-STERNS & 109 & $3.00 \%$ & 22,309 \\
\hline 11 & CHASE & 132 & $2.44 \%$ & 18,167 \\
\hline 12 & DLJ & 89 & $2.09 \%$ & 15,544 \\
\hline 13 & DEUTSCHE-BANK & 45 & $1.04 \%$ & 7,732 \\
\hline 14 & UNION-BANK-SWITZERLAND & 81 & $0.97 \%$ & 7,257 \\
\hline 15 & SMITH-BARNEY & 80 & $0.89 \%$ & 6,629 \\
\hline 16 & BANKERS-TRUST & 20 & $0.46 \%$ & 3,427 \\
\hline 17 & NATIONS-BANK & 51 & $0.38 \%$ & 2,820 \\
\hline 18 & BANK-ONE & 28 & $0.38 \%$ & 2,803 \\
\hline 19 & DILLON-READ & 19 & $0.34 \%$ & 2,507 \\
\hline \multirow[t]{2}{*}{20} & PAINE-WEBBER & 24 & $0.32 \%$ & 2,354 \\
\hline & Overall & & $97.48 \%$ & 744,643 \\
\hline \multicolumn{5}{|c|}{ Panel C: Top- 20 Equity Underwriters } \\
\hline Rank & Bank & $\begin{array}{l}\text { Number } \\
\text { of Deals }\end{array}$ & $\begin{array}{r}\text { Market } \\
\text { share }\end{array}$ & $\begin{array}{r}\text { Amount } \\
\text { (\$ Million) }\end{array}$ \\
\hline 1 & GOLDMAN-SACHS & 200 & $17.05 \%$ & 47,033 \\
\hline 2 & MERRILL & 236 & $15.61 \%$ & 43,082 \\
\hline 3 & MORGAN-STANLEY & 180 & $15.29 \%$ & 42,195 \\
\hline 4 & CSFB & 131 & $9.11 \%$ & 25,129 \\
\hline 5 & DLJ & 98 & $5.89 \%$ & 16,247 \\
\hline 6 & CITICORP & 74 & $5.86 \%$ & 16,167 \\
\hline 7 & J-P-MORGAN & 40 & $5.58 \%$ & 15,397 \\
\hline 8 & LEHMAN & 88 & $5.09 \%$ & 14,051 \\
\hline 9 & SALOMON & 76 & $4.82 \%$ & 13,301 \\
\hline 10 & BEAR-STERNS & 57 & $2.95 \%$ & 8,148 \\
\hline 11 & BANK-AMERICA & 24 & $1.43 \%$ & 3,948 \\
\hline 12 & SMITH-BARNEY & 42 & $1.41 \%$ & 3,882 \\
\hline 13 & BANKERS-TRUST & 34 & $1.32 \%$ & 3,636 \\
\hline 14 & ALEX-BROWN & 21 & $1.10 \%$ & 3,044 \\
\hline 15 & DEUTSCHE-BANK & 26 & $0.97 \%$ & 2,665 \\
\hline 16 & UNION-BANK-SWITZERLAND & 22 & $0.65 \%$ & 1,802 \\
\hline 17 & MONTGOMERY & 19 & $0.64 \%$ & 1,773 \\
\hline 18 & PAINE-WEBBER & 26 & $0.52 \%$ & 1,438 \\
\hline 19 & PRUDENTIAL & 19 & $0.42 \%$ & 1,169 \\
\hline \multirow[t]{2}{*}{20} & ROBERTSON-STEPHENS & 9 & $0.28 \%$ & 770 \\
\hline & Overall & & $95.99 \%$ & 275,927 \\
\hline
\end{tabular}




\section{TABLE 3}

\section{Summary Statistics for Key Loan, Debt Issue and Equity Issue Characteristics}

The table below provides summary statistics of various loan and borrower characteristics. Panel A reports these for the Loan Facilities sample. Panel B and Panel C report these for Debt issue and Equity issue samples respectively. AISD is the "All In Spread-Drawn", which is the all-inclusive cost of a drawn loan to the borrower. This equals the coupon spread over LIBOR on the drawn amount plus the annual fee and is reported in basis points. Loan Facility Size is the dollar amount of loan facility in millions. Maturity is length in months between facility activation date and maturity date. Syndicate, Secured, and Investment Grade are percent of facility that have the stated attribute. To be classified as Investment Grade the loan has to be rated BBB or above by S\&P. Proceeds is the amount of proceeds in $\$$ millions from the Debt or the Equity issue. Underwriting fee (i.e. gross spread) is the fee charged divided by the proceeds and is reported in basis points. All data has been winsorized at the 1 percentile and the 99 th percentile to remove the extreme observations.

\begin{tabular}{|c|c|c|c|c|c|c|c|c|}
\hline Variable & $N$ & Mean & $\begin{array}{l}\text { Std. } \\
\text { Dev. }\end{array}$ & Min & $\begin{array}{l}\mathbf{2 5}^{t h} \\
\text { Pctile }\end{array}$ & Median & $\begin{array}{l}\mathbf{7 5}^{t h} \\
\text { Pctile }\end{array}$ & $\operatorname{Max}$ \\
\hline \multicolumn{9}{|c|}{ Panel A: Loan Facilities Sample } \\
\hline AISD & 21,843 & 211.07 & 129.64 & 17.5 & 100.00 & 200.00 & 300.00 & 580.00 \\
\hline Loan Facility Size & 25,476 & 161.51 & 312.26 & 0.50 & 10.78 & 50.00 & 151.70 & 2000.00 \\
\hline Maturity & 22,667 & 44.42 & 27.51 & 3 & 18.00 & 37.00 & 60.00 & 120 \\
\hline Secured & 16,016 & 0.82 & 0.38 & 0 & 1 & 1 & 1 & 1 \\
\hline Investment Grade & 8,484 & 0.48 & 0.50 & 0 & 0 & 0 & 1 & 1 \\
\hline Syndicate & 25,470 & 0.77 & 0.42 & 0 & 1 & 1 & 1 & 1 \\
\hline \multicolumn{9}{|c|}{ Panel B: Debt Issues Sample } \\
\hline Proceeds & 3,923 & 189.81 & 249.11 & 0.20 & 33.0 & 124.8 & 249.3 & 3237.3 \\
\hline Fee (Gross Spread) & 3,070 & 88.80 & 72.33 & 0.10 & 55.00 & 65.00 & 87.50 & 465.00 \\
\hline \multicolumn{9}{|c|}{ Panel C: Equity Issues Sample } \\
\hline \multicolumn{9}{|c|}{ Initial Public Offerings (IPOs) } \\
\hline Proceeds & 283 & 200.12 & 536.04 & 10.80 & 51.00 & 96.00 & 149.80 & 7322.40 \\
\hline Fee (Gross Spread) & 283 & 650.96 & 73.96 & 250.00 & 600.00 & 700.00 & 700.00 & 750.00 \\
\hline \multicolumn{9}{|c|}{ Seasoned Equity Offerings (SEOs) } \\
\hline Proceeds & 1074 & 204.13 & 277.05 & 1.50 & 63.00 & 116.50 & 220.00 & 2733.70 \\
\hline Fee (Gross Spread) & 1012 & 426.73 & 114.80 & 24.80 & 347.55 & 448.80 & 500.75 & 812.50 \\
\hline
\end{tabular}




\section{TABLE 4}

\section{Impact of Lending Relationships on Probability of Getting Future Lending Business}

This table provides the logit regression estimates of the following equation.

$$
\begin{aligned}
(\text { CHOSEN })_{m} & =\beta_{0}+\beta_{1}\left(\text { LOANREL }(M)_{m}^{\text {BankLoans }}\right)+\beta_{2}(\text { LOAN MKT SHARE })_{m} \\
& +\beta_{3}(\text { LOCATION })_{m}+\sum \beta_{k}\left(\text { CONTROL }_{k}\right) .
\end{aligned}
$$

For each loan facility $i$ we create a choice set of 40 potential lenders, thus creating 40 loan-bank pairs. The top 40 commercial banks in the previous year form the consideration set for each firm in the current year. The dependent variable $(\mathrm{CHOSEN})_{m}$ that takes a value of 1 if a bank $m$ was retained as the lead bank for that loan transaction and 0 otherwise. We use 3 proxies for relationship -

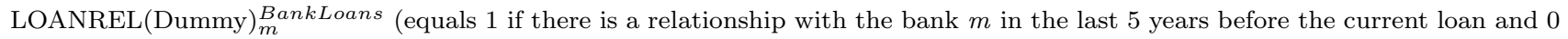

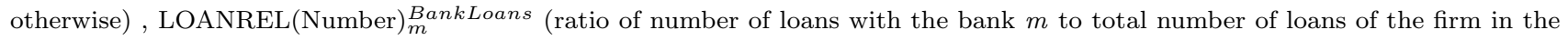

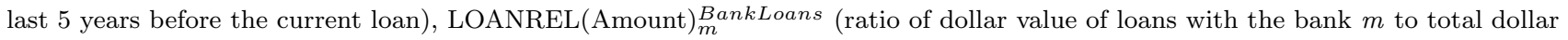
value of loans of the firm in the last 5 years before the current loan). (LOAN MKT SHARE) $m$ is the share of total lending done by bank $m$ in the year prior to the year of loan facility $i$. (LOCATION) $m$ is a dummy variable that equals 1 if both bank $m$ and the borrower have their respective head offices in the same state and 0 otherwise. In the panel at the bottom we illustrate the economic impact that various variables have on probability of a bank being chosen as the lead lender. We use the specification estimated in column 1 to estimate probability of a bank being chosen as the lead lender if all variables except the variable being examined are held equal to their mean. We then estimate the predicted probability as the variable being examined goes from 0 to 1 (except for LOAN MKT SHARE which is varied from 1\% market share (approximately lowest market share of a top 20 lender) to $10 \%$ market share (approximately highest market share of a top 20 lender)). For example, the first row reports the predicted probability of a bank being chosen as a lead lender if it did not have a past lending relationship with a borrower (LOANREL(Dummy $)^{\text {BankLoans }=0)}$ and if all other variables are assumed equal to their means. The next row reports the predicted probability of being chosen if the bank did have past lending relationship (LOANREL(Dummy) $)^{\text {BankLoans }}=1$ ) again holding all else constant at their means. The third row reports the increase in predicted probability of being chosen as the lead lender for relationship lender compared to a lender with no prior relationship. Numbers in the parentheses are standard errors which are corrected for heteroscedasticity and clustering (*** Significant at one percent level, ${ }^{* *}$ Significant at five percent level,${ }^{*}$ Significant at 10 percent level). 


\begin{tabular}{|c|c|c|c|}
\hline & (1) & $(2)$ & (3) \\
\hline Const. & $\begin{array}{c}-3.53^{* * *} \\
(.41)\end{array}$ & $\begin{array}{c}-2.94^{* * *} \\
(.4)\end{array}$ & $\begin{array}{c}-3.32^{* * *} \\
(.42)\end{array}$ \\
\hline LOANREL(Dummy) ${ }_{m}^{\text {BankLoans }}$ & $\begin{array}{c}3.27^{* * *} \\
(.03)\end{array}$ & & \\
\hline LOANREL(Number) ${ }_{m}^{\text {BankLoans }}$ & & $\begin{array}{c}4.59^{* * *} \\
(.04)\end{array}$ & \\
\hline LOANREL(Amount) ${ }_{m}^{\text {BankLoans }}$ & & & $\begin{array}{c}4.23^{* * *} \\
(.04)\end{array}$ \\
\hline$(\text { LOAN MKT SHARE })_{m}$ & $\begin{array}{c}12.23^{* * *} \\
(.21)\end{array}$ & $\begin{array}{c}11.37^{* * *} \\
(.21)\end{array}$ & $\begin{array}{c}11.32^{* * *} \\
(.22)\end{array}$ \\
\hline LOCATION & $\begin{array}{c}.38^{* * *} \\
(.05)\end{array}$ & $\begin{array}{c}.44^{* * *} \\
(.05)\end{array}$ & $\begin{array}{c}.39^{* * *} \\
(.05)\end{array}$ \\
\hline Industry Dummies & Yes & Yes & Yes \\
\hline Year Dummies & Yes & Yes & Yes \\
\hline Loan Purpose Dummies & Yes & Yes & \\
\hline Obs. & 416239 & 416239 & 416239 \\
\hline Pseudo $R^{2}$ & .32 & .31 & .32 \\
\hline \multicolumn{4}{|c|}{$\begin{array}{l}\text { Impact of past lending relationship on probability of being chosen as the } \\
\text { lead lender using the column (1) specification }\end{array}$} \\
\hline & & \multicolumn{2}{|r|}{ Probability of being chosen } \\
\hline$L O A N R E L(\text { Dummy })_{m}^{\text {BankLoans }}=0$ & & \multicolumn{2}{|r|}{$2.73 \%$} \\
\hline LOANREL $(\text { Dummy })_{m}^{\text {BankLoans }}=1$ & & \multicolumn{2}{|r|}{$42.46 \%$} \\
\hline Increase in probability & & \multicolumn{2}{|r|}{$39.73 \%$} \\
\hline$(L O A N M K T S H A R E)_{m}=1 \%$ & & \multicolumn{2}{|r|}{$3.16 \%$} \\
\hline$(L O A N M K T S H A R E)_{m}=10 \%$ & & \multicolumn{2}{|r|}{$8.93 \%$} \\
\hline Increase in probability & & \multicolumn{2}{|r|}{$5.77 \%$} \\
\hline$(L O C A T I O N)_{m}=0$ & & \multicolumn{2}{|r|}{$3.54 \%$} \\
\hline$(L O C A T I O N)_{m}=1$ & & \multicolumn{2}{|r|}{$5.08 \%$} \\
\hline Increase in probability & & \multicolumn{2}{|r|}{$1.54 \%$} \\
\hline
\end{tabular}




\section{TABLE 5}

\section{Borrower Information asymmetries, Lending Relationships and Probability of Getting Future Lending Business}

Panel A of this table provides the logit regression estimates of the following equation.

$$
\begin{aligned}
(C H O S E N)_{m} & =\beta_{0}+\beta_{1}\left(L O A N R E L(M)_{m}^{\text {BankLoans }}\right)+\beta_{2}(\text { LOAN MKT SHARE })_{m}+\beta_{3}\left({\text { LOCATION })_{m}}\right. \\
& +\beta_{4}(\text { MIDDLE })+\beta_{5}(B I G)+\beta_{6}\left(\text { MIDDLE*LOANREL }(M)_{m}^{\text {BankLoans }}\right) \\
& +\beta_{7}\left(\text { BIG*LOANREL }(M)_{m}^{\text {BankLoans }}\right)+\sum \beta_{k}\left(C_{\text {CONTROL }}\right) .
\end{aligned}
$$

The model is the same as one estimated in Table 4 with one difference, two dummy variables MIDDLE and BIG which take the value 1 if the borrower falls in the stated size tercile (as measured by the book value of assets) and 0 otherwise have been added. Also added are two interaction terms, multiplying the relationship variables with MIDDLE and BIG.

Panel B reports the estimates of the following logit regression:

$$
\begin{aligned}
(\text { CHOSEN })_{m} & =\beta_{0}+\beta_{1}\left(\text { LOANREL }(M)_{m}^{\text {BankLoans }}\right)+\beta_{2}(\text { LOAN MKT SHARE })_{m}+\beta_{3}(\text { LOCATION })_{m} \\
& +\beta_{4}(\text { NOT RATED })+\beta_{5}\left(\text { NOT RATED*LOANREL }(M)_{m}^{\text {BankLoans }}\right)+\sum \beta_{k}\left(C O N T R O L_{k}\right)
\end{aligned}
$$

Again, the model is same as the one estimated in Table 4 with an additional variable NOT RATED (and the interaction with relationship measures) which equals one if the loan is not rated and zero otherwise.

Panel C provides estimates the following logit regression:

$$
\begin{aligned}
(\text { CHOSEN })_{m} & =\beta_{0}+\beta_{1}\left(\text { LOANREL }(M)_{m}^{\text {BankLoans }}\right)+\beta_{2}(\text { LOAN MKT SHARE })_{m}+\beta_{3}(\text { LOCATION })_{m} \\
& +\beta_{4}(\text { INVESTMENT GRADE })+\beta_{5}\left(\text { INVESTMENT GRADE* }\left(\text { LOANREL }(M)_{m}^{\text {BankLoans }}\right)\right. \\
& +\sum \beta_{k}\left(\text { CONTROL }_{k}\right) .
\end{aligned}
$$

The model is same as the one estimated in Table 4 with an additional variable INVESTMENT GRADE (and the interaction with relationship measures) which equals one if the loan is rated $\mathrm{BBB}$ or above by $\mathrm{S} \& \mathrm{P}$ and zero otherwise.

At the bottom of each panel we illustrate the economic impact of past lending relationships on probability of being chosen as the lead lender (across borrowers with different levels of information opacity) using the specification estimated in column 1. Specifically, we estimate probability of a bank being chosen as the lead lender if all variables except the relationship variables and the information opacity measure (size, credit rating, etc.) are held equal to their mean. Then the impact of past relationship on probability of being chosen is measured across different information opacity measures for each size tercile (e.g. by setting each size variable equal to 1 while keeping the other size variables equal to 0 ). Numbers in the parentheses are standard errors which are corrected for heteroscedasticity and clustering $\left(* * *\right.$ Significant at one percent level, ${ }^{* *}$ Significant at five percent level ${ }^{*}$ Significant at 10 percent level). 


\begin{tabular}{|c|c|c|c|}
\hline & $(1)$ & $(2)$ & $(3)$ \\
\hline Const. & $\begin{array}{c}-4.45^{* * *} \\
(.39)\end{array}$ & $\begin{array}{c}-4.01^{* * *} \\
(.38)\end{array}$ & $\begin{array}{c}-4.3^{* * *} \\
(.4)\end{array}$ \\
\hline LOANREL(Dummy) ${ }_{m}^{\text {BankLoans }}$ & $\begin{array}{c}5.01^{* * *} \\
(.09)\end{array}$ & & \\
\hline LOANREL(Number) ${ }_{m}^{\text {BankLoans }}$ & & $\begin{array}{c}5.88^{* * *} \\
(.13)\end{array}$ & \\
\hline LOANREL(Amount) BankLoans & & & $\begin{array}{c}5.7^{* * *} \\
(.12)\end{array}$ \\
\hline$(\text { LOAN MKT SHARE })_{m}$ & $\begin{array}{c}12.7^{* * *} \\
(.21)\end{array}$ & $\begin{array}{c}11.97^{* * *} \\
(.22)\end{array}$ & $\begin{array}{c}11.9^{* * *} \\
(.22)\end{array}$ \\
\hline$(\text { LOCATION })_{m}$ & $\begin{array}{c}.36^{* * *} \\
(.05)\end{array}$ & $\begin{array}{c}.44^{* * *} \\
(.05)\end{array}$ & $\begin{array}{c}.38^{* * *} \\
(.05)\end{array}$ \\
\hline MIDDLE & $\begin{array}{c}.37^{* * *} \\
(.05)\end{array}$ & $\begin{array}{c}.41^{* * *} \\
(.05)\end{array}$ & $\begin{array}{c}.39^{* * *} \\
(.05)\end{array}$ \\
\hline $\mathrm{BIG}$ & $\begin{array}{c}1.26^{* * *} \\
(.05)\end{array}$ & $\begin{array}{c}1.34^{* * *} \\
(.05)\end{array}$ & $\begin{array}{c}1.31^{* * *} \\
(.05)\end{array}$ \\
\hline MIDDLE x LOANREL(Dummy) ${ }_{m}^{\text {BankLoans }}$ & $\begin{array}{c}-.88^{* * *} \\
(.1)\end{array}$ & & \\
\hline BIG x LOANREL(Dummy) $\underset{m}{\text { BankLoans }}$ & $\begin{array}{c}-2.3^{* * *} \\
(.1)\end{array}$ & & \\
\hline MIDDLE x LOANREL(Number $)_{m}^{\text {BankLoans }}$ & & $\begin{array}{c}-.56^{* * *} \\
(.15)\end{array}$ & \\
\hline BIG x LOANREL(Number) BankLoans & & $\begin{array}{c}-1.89^{* * *} \\
(.14)\end{array}$ & \\
\hline MIDDLE x LOANREL(Amount) ${ }_{m}^{\text {BankLoans }}$ & & & $\begin{array}{c}-.59^{* * *} \\
(.13)\end{array}$ \\
\hline BIG x LOANREL(Amount) ${ }_{m}^{\text {BankLoans }}$ & & & $\begin{array}{c}-2.07^{* * *} \\
(.13)\end{array}$ \\
\hline Industry Dummies & Yes & Yes & Yes \\
\hline Year Dummies & Yes & Yes & Yes \\
\hline Loan Purpose Dummies & Yes & Yes & Yes \\
\hline Obs. & 401699 & 401699 & 401699 \\
\hline Pseudo $R^{2}$ & .33 & .32 & .33 \\
\hline \multicolumn{4}{|c|}{$\begin{array}{l}\text { Impact of past lending relationship on probability of being chosen as the } \\
\text { lead lender using the column (1) specification }\end{array}$} \\
\hline & \multicolumn{3}{|c|}{ Probability of being chosen } \\
\hline & $\underline{\text { Small }}$ & $\underline{\text { Medium }}$ & $\underline{B i g}$ \\
\hline LOANREL $(\text { Dummy })_{m}^{\text {BankLoans }}=0$ & $1.21 \%$ & $1.74 \%$ & $4.14 \%$ \\
\hline LOANREL $(\text { Dummy })_{m}^{\text {BankLoans }}=1$ & $64.87 \%$ & $52.24 \%$ & $39.28 \%$ \\
\hline Increase in probability & $63.66 \%$ & $50.50 \%$ & $35.14 \%$ \\
\hline
\end{tabular}




\begin{tabular}{|c|c|c|c|}
\hline & (1) & $(2)$ & (3) \\
\hline Const. & $\begin{array}{c}-3.2^{* * *} \\
(.39)\end{array}$ & $\begin{array}{c}-2.57^{* * *} \\
(.38)\end{array}$ & $\begin{array}{c}-2.97^{* * *} \\
(.41)\end{array}$ \\
\hline LOANREL(Dummy) ${ }_{m}^{\text {BankLoans }}$ & $\begin{array}{c}2.87^{* * *} \\
(.03)\end{array}$ & & \\
\hline LOANREL(Number) ${ }_{m}^{\text {BankLoans }}$ & & $\begin{array}{c}4.19^{* * *} \\
(.06)\end{array}$ & \\
\hline LOANREL(Amount) BankLoans & & & $\begin{array}{c}3.82^{* * *} \\
(.05)\end{array}$ \\
\hline$(\mathrm{LOAN} \text { MKT SHARE })_{m}$ & $\begin{array}{c}12.41^{* * *} \\
(.21)\end{array}$ & $\begin{array}{c}11.65^{* * *} \\
(.22)\end{array}$ & $\begin{array}{c}11.58^{* * *} \\
(.22)\end{array}$ \\
\hline$(\text { LOCATION })_{m}$ & $\begin{array}{c}.37^{* * *} \\
(.05)\end{array}$ & $\begin{array}{c}.45^{* * *} \\
(.05)\end{array}$ & $\begin{array}{c}.39 * * * \\
(.05)\end{array}$ \\
\hline NOT RATED & $\begin{array}{c}-.7^{* * *} \\
(.04)\end{array}$ & $\begin{array}{c}-.7^{* * *} \\
(.03)\end{array}$ & $\begin{array}{c}-.69^{* * *} \\
(.04)\end{array}$ \\
\hline NOT RATED x LOANREL(Dummy) ${ }_{m}^{\text {BankLoans }}$ & $\begin{array}{c}1.12^{* * *} \\
(.06)\end{array}$ & & \\
\hline NOT RATED x LOANREL(Number) BankLoans & & $\begin{array}{c}.97^{* * *} \\
(.09)\end{array}$ & \\
\hline NOT RATED x LOANREL(Amount) ${ }_{m}^{\text {BankLoans }}$ & & & $\begin{array}{c}1.06^{* * *} \\
(.08)\end{array}$ \\
\hline Industry Dummies & Yes & Yes & Yes \\
\hline Year Dummies & Yes & Yes & Yes \\
\hline Loan Purpose Dummies & Yes & Yes & Yes \\
\hline Obs. & 416239 & 416239 & 416239 \\
\hline Pseudo $R^{2}$ & .32 & .32 & .33 \\
\hline
\end{tabular}

\begin{tabular}{|c|c|c|}
\hline \multicolumn{3}{|c|}{$\begin{array}{l}\text { Impact of past lending relationship on probability of being chosen as the } \\
\text { lead lender using the column (1) specification }\end{array}$} \\
\hline & \multicolumn{2}{|c|}{ Probability of being chosen } \\
\hline & Not Rated & Rated \\
\hline LOANREL $(\text { Dummy })_{m}^{\text {BankLoans }}=0$ & $1.84 \%$ & $3.66 \%$ \\
\hline LOANREL $(\text { Dummy })_{m}^{\text {BankLoans }}=1$ & $50.31 \%$ & $40.06 \%$ \\
\hline Increase in probability & $48.47 \%$ & $36.40 \%$ \\
\hline
\end{tabular}




\begin{tabular}{|c|c|c|c|}
\hline & $(1)$ & $(2)$ & $(3)$ \\
\hline Const. & $\begin{array}{c}-2.98^{* * *} \\
(.55)\end{array}$ & $\begin{array}{c}-2.34^{* * *} \\
(.53)\end{array}$ & $\begin{array}{c}-2.7^{* * *} \\
(.55)\end{array}$ \\
\hline LOANREL(Dummy) ${ }_{m}^{\text {BankLoans }}$ & $\begin{array}{c}3.18^{* * *} \\
(.05)\end{array}$ & & \\
\hline LOANREL(Number) ${ }_{m}^{\text {BankLoans }}$ & & $\begin{array}{c}4.61^{* * *} \\
(.08)\end{array}$ & \\
\hline LOANREL(Amount) BankLoans & & & $\begin{array}{c}4.24^{* * *} \\
(.07)\end{array}$ \\
\hline$(\text { LOAN MKT SHARE })_{m}$ & $\begin{array}{c}13.82^{* * *} \\
(.27)\end{array}$ & $\begin{array}{c}12.55^{* * *} \\
\quad(.29)\end{array}$ & $\begin{array}{c}12.58^{* * *} \\
(.29)\end{array}$ \\
\hline$(\text { LOCATION })_{m}$ & $\begin{array}{c}.39^{* * *} \\
(.06)\end{array}$ & $\begin{array}{c}.45^{* * *} \\
(.07)\end{array}$ & $\begin{array}{c}.39^{* * *} \\
(.07)\end{array}$ \\
\hline INVESTMENT GRADE & $\begin{array}{c}.52^{* * *} \\
(.06)\end{array}$ & $\begin{array}{l}.49^{* * *} \\
(.05)\end{array}$ & $\begin{array}{c}.51^{* * *} \\
(.05)\end{array}$ \\
\hline INVESTMENT GRADE x LOANREL(Dummy) ${ }_{m}^{\text {BankLoans }}$ & $\begin{array}{c}-.59^{* * *} \\
(.07)\end{array}$ & & \\
\hline INVESTMENT GRADE x LOANREL(Number) ${ }_{m}^{\text {BankLoans }}$ & & $\begin{array}{c}-.75^{* * *} \\
\quad(.11)\end{array}$ & \\
\hline INVESTMENT GRADE x LOANREL(Amount) ${ }_{m}^{\text {BankLoans }}$ & & & $\begin{array}{c}-.76^{* * *} \\
(.1)\end{array}$ \\
\hline Industry Dummies & Yes & Yes & Yes \\
\hline Year Dummies & Yes & Yes & Yes \\
\hline Loan Purpose Dummies & Yes & Yes & Yes \\
\hline Obs. & 213420 & 213420 & 213420 \\
\hline Pseudo $R^{2}$ & .3 & .29 & .3 \\
\hline \multicolumn{4}{|c|}{$\begin{array}{l}\text { Impact of past lending relationship on probability of being chosen as the } \\
\text { lead lender using the column (1) specification }\end{array}$} \\
\hline & \multicolumn{3}{|c|}{ Probability of being chosen } \\
\hline & $\underline{\text { Non Investment Grade }}$ & & $\underline{\text { Investment Grade }}$ \\
\hline LOANREL $(\text { Dummy })_{m}^{\text {BankLoans }}=0$ & $2.80 \%$ & & $4.64 \%$ \\
\hline LOANREL $(\text { Dummy })_{m}^{\text {BankLoans }}=1$ & $40.99 \%$ & & $39.08 \%$ \\
\hline Increase in probability & $38.19 \%$ & & $34.44 \%$ \\
\hline
\end{tabular}




\section{TABLE 6 \\ Impact of Lending Relationships on Probability of Getting Future Debt Underwriting Business}

This table provides the logit regression estimates of the following equation.

$$
\begin{aligned}
(\text { RETAIN })_{m}^{\text {Lead-debt }} & =\beta_{0}+\beta_{1}(\text { PROCEEDS })+\beta_{2}\left(\text { LOANREL }(M)_{m}^{\text {PublicDebt }}\right)+\beta_{3}\left(\text { Lead }- \text { DEBTREL }(M)_{m}^{\text {PublicDebt }}\right) \\
& +\beta_{4}\left(\text { Lead }- \text { EQUITYREL }(M)_{m}^{\text {PublicDebt }}\right)+\beta_{5}(\text { LOAN MKT SHARE })_{m} \\
& +\beta_{6}(\text { TOP TIER }-D E B T)_{m}+\beta_{7}(M I D T I E R-D E B T)_{m} \\
& +\beta_{8}(T O P T I E R-E Q U I T Y)_{m}+\beta_{9}(\text { MID TIER }-E Q U I T Y)_{m}+\sum \beta_{k}\left(C O N T R O L_{k}\right)
\end{aligned}
$$

For each debt issue, we create a dummy variable (RETAIN) ${ }_{m}^{\text {Lead-debt }}$ that takes a value of 1 if a bank $m$ was retained as the "lead underwriter" for that debt issue transaction and 0 otherwise. For each debt underwriting deal $i$ we create a choice set of at least 20 potential underwriters, thus creating at least 20 deal-underwriter pairs. The top 20 debt underwriters (based on market share) from the previous year and all commercial banks eligible to do debt underwriting in the previous year form the consideration set for each issuer in the current year. For each institution in a transaction-bank pair we estimate relationships across 3 markets: the bank loan market, the debt underwriting market and the equity underwriting market. Within each market we use 3 different proxies of relationship strength; for any bank $m$ : LOANREL(Dummy) ${ }_{m}^{\text {uublicDebt }}(1$ if there is a loan relationship with the bank $m$ in the last 5 years before the present debt underwriting transaction and 0 otherwise), LOANREL(Number) ${ }_{m}^{P u b l i c D e b t}$ (ratio of number of loan deals with the bank $m$ to total number of loan deals of the firm in the last 5 years before the current debt underwriting transaction),

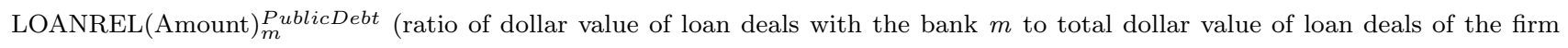
in the last 5 years before the current debt underwriting transaction). Similarly, Lead-DEBTREL(Dummy) ${ }_{m}^{P u b l i c D e b t}(1$ if there is a debt underwriting relationship in lead underwriter capacity with the bank $m$ in the last 5 years before the present debt underwriting transaction and 0 otherwise), Lead-DEBTREL(Number) ${ }_{m}^{\text {PublicDebt }}$ (ratio of number of debt underwriting deals in lead underwriter capacity with bank $m$ to total number of debt underwriting deals of the firm in the last 5 years before the current debt underwriting

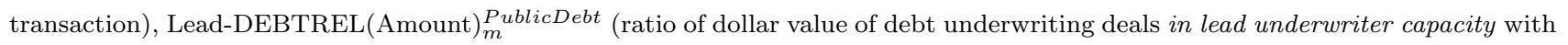
bank $m$ to total dollar value of debt underwriting deals of the firm in the last 5 years before the current debt underwriting transaction). Finally, Lead-EQUITYREL(Dummy) ${ }_{m}^{\text {PublicDebt }}$ ( 1 if there is an equity underwriting relationship in lead underwriter capacity bank $m$ in the last 5 years before the present debt underwriting transaction and 0 otherwise), Lead-EQUITYREL(Number $)_{m}^{P u b l i c D e b t}($ ratio of number of equity underwriting deals with in lead underwriter capacity bank $m$ to total number of equity underwriting deals of the firm in the last 5 years before the current debt underwriting transaction), Lead -EQUITYREL(Amount) ${ }_{m}^{P u b l i c D e b t}$ (ratio of dollar value of equity underwriting deals in lead underwriter capacity with bank $m$ to total dollar value of equity underwriting deals of the firm in the last 5 years before the current debt underwriting transaction). PROCEEDS is the amount raised in $\$$ millions for the debt underwriting transaction (reported coefficient has been divided by 1,000). (LOAN MKT SHARE) $m$ is the market share of the bank $m$ in the loan market, in the year before the current debt underwriting transaction. Similar calculations are done to estimate market shares for debt underwriting and equity underwriting market. (TOP TIER-DEBT) $m$ and (TOP TIER-EQUITY) $m$ are dummy variables that equal to 1 if the bank $m$ is ranked in the top 5 debt and equity underwriters respectively and 0 otherwise. $(\text { MID TIER-DEBT })_{m}$ and (MID TIER-EQUITY $)_{m}$ are dummy variables that equal to 1 if the bank $m$ is ranked from 6th to 15 th in debt and equity underwriting respectively and 0 otherwise.

At the bottom of each panel we illustrate the economic impact of past lending, debt underwriting and equity underwriting relationships on probability of being chosen as the debt underwriter using the specifications estimated in columns 4 . The first row reports the probability of a non-relationship bank (LOANREL(Number) ${ }^{\text {PublicDebt }}=0$ ) being chosen as the debt underwriter if all other variables

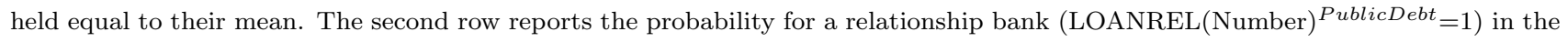
same way. Numbers in the parentheses are standard errors which are corrected for heteroscedasticity and clustering (*** Significant at one percent level, ${ }^{* *}$ Significant at five percent level ${ }^{*}$ Significant at 10 percent level). 


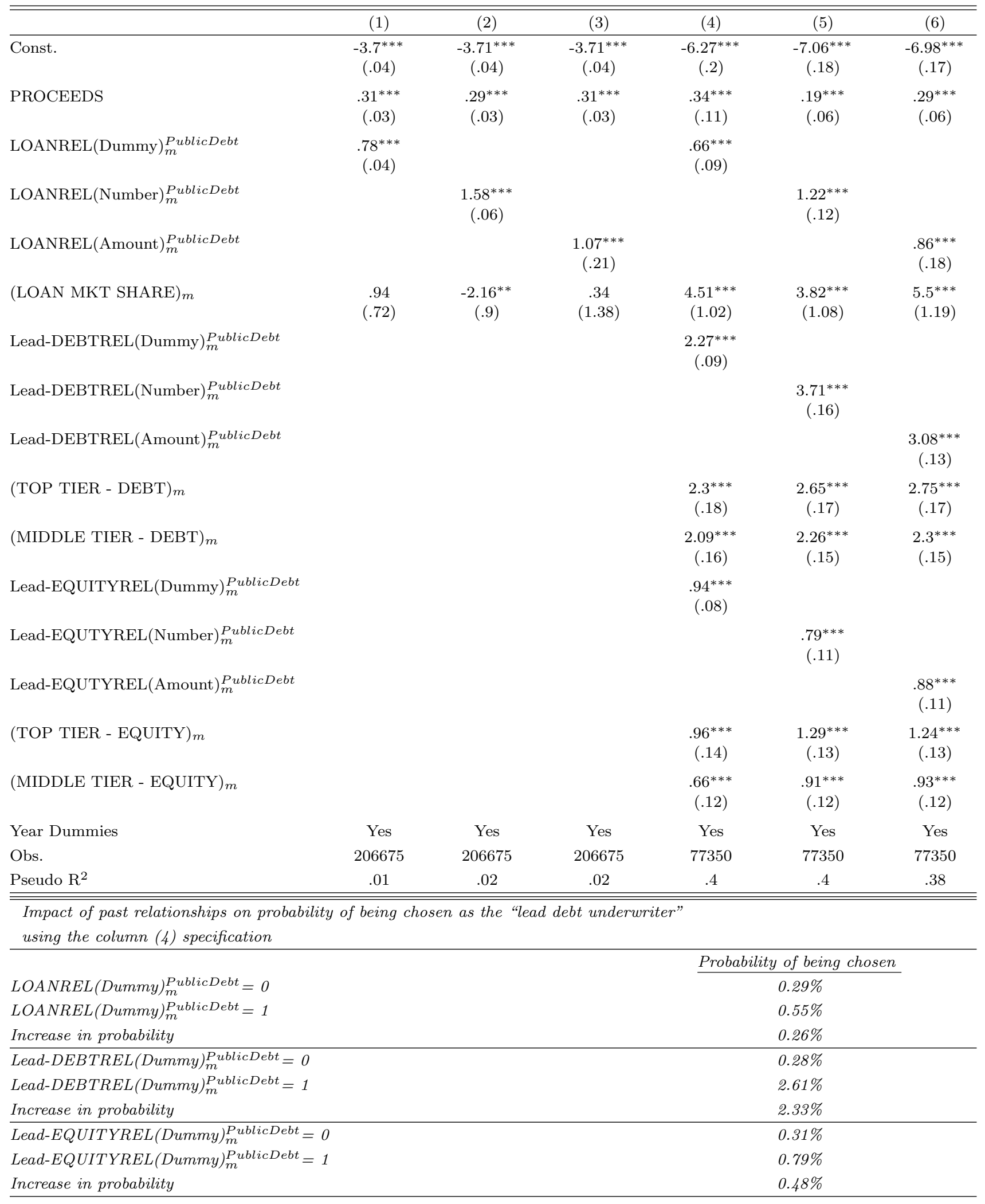




\section{TABLE 7}

\section{Impact of Lending Relationships on Probability of Getting Future Equity Underwriting Business - Seasoned Equity Offerings (SEOs)}

This table provides the logit regression estimates of the following equation.

$$
\begin{aligned}
(R E T A I N)_{m}^{\text {Lead-SEO }} & =\beta_{0}+\beta_{1}(\text { PROCEEDS })+\beta_{2}\left(\text { LOANREL }(M)_{m}^{\text {PublicEquity }}\right)+\beta_{3}\left(\text { Lead }- \text { EQUITYREL }(M)_{m}^{\text {PublicEquity }}\right) \\
& +\beta_{4}\left(\text { Lead }- \text { DEBTREL }(M)_{m}^{\text {PublicEquity }}\right)+\beta_{5}(\text { LOAN MKT SHARE })_{m} \\
& +\beta_{6}(\text { TOP TIER }-D E B T)_{m}+\beta_{7}(M I D D L E T I E R-D E B T)_{m} \\
& +\beta_{8}(T O P T I E R-E Q U I T Y)_{m}+\beta_{9}(M I D D L E T I E R-E Q U I T Y)_{m}+\sum \beta_{k}\left(C O N T R O L_{k}\right) .
\end{aligned}
$$

For each equity issue, we create a dummy variable (RETAIN) ${ }_{m}^{\operatorname{Lead}-S E O}$ that takes a value of 1 if a bank $m$ was retained as the "lead underwriter" for that equity issue transaction and 0 otherwise. For each equity underwriting deal $i$ we create a choice set of at least 20 potential underwriters, thus creating at least 20 deal-underwriter pairs. The top 20 equity underwriters (based on market share) from the previous year and all commercial banks eligible to do equity underwriting in the previous year form the consideration set for each issuer in the current year. For each institution in a transaction-bank pair we estimate relationships across 3 markets: the bank loan market, the debt underwriting market and the equity underwriting market. Within each market we use 3 different proxies of relationship strength; for any bank $m$ : LOANREL(Dummy) ${ }_{m}^{\text {PublicEquity }}$ (1 if there is a loan relationship with bank $m$ in the last 5 years before the current equity underwriting transaction and 0 otherwise), LOANREL(Number) ${ }_{m}^{\text {PublicEquity }}$ (ratio of number of loan deals with bank $m$ to total number of loan deals of the firm in the last 5 years before the current equity underwriting transaction), LOANREL(Amount) ${ }_{m}^{P u b l i c E q u i t y}$ (ratio of dollar value of loan deals with bank $m$ to total dollar value of loan deals of the firm in the last 5 years before the current equity underwriting transaction). Lead-DEBTREL(Dummy) PublicEquity $(1$ if there is a debt underwriting relationship in lead underwriter capacity with bank $m$ in the last 5 years before the present equity underwriting transaction and 0 otherwise), Lead-DEBTREL(Number) PublicEquity (ratio of number of debt underwriting deals in lead underwriter capacity with bank $m$ to total number of debt underwriting deals of the firm in the last 5 years before the current equity underwriting transaction), Lead-DEBTREL(Amount) PublicEquity (ratio of dollar value of debt underwriting deals in lead underwriter capacity with bank $m$ to total dollar value of debt underwriting deals of the firm in the last 5 years before the current equity underwriting transaction). Lead-EQUITYREL(Dummy) PublicEquity (1 if there is an equity underwriting relationship in lead underwriter capacity with bank $m$ in the last 5 years before the present equity underwriting transaction and 0 otherwise), Lead-EQUITYREL(Number) PublicEquity (ratio of number of equity underwriting deals in lead underwriter capacity with bank $m$ to total number of equity underwriting deals of the firm in the last 5 years before the current equity underwriting transaction), Lead-EQUITYREL(Amount) PublicEquity (ratio of dollar value of equity underwriting deals in lead underwriter capacitywith bank $m$ to total dollar value of equity underwriting deals of the firm in the last 5 years before the current equity underwriting transaction). PROCEEDS is the amount raised in $\$$ millions for the equity underwriting transaction (reported coefficient has been divided by 1,000). (LOAN MKT SHARE) $m$ is the market share of the bank $m$ in the loan market, in the year before the current equity underwriting transaction. (TOP TIER-DEBT) $m$ and (TOP TIER-EQUITY) $m$ are dummy variables that equal to 1 if the bank $m$ is ranked in the top 5 debt and equity underwriters respectively and 0 otherwise. (MID TIER-DEBT) ${ }_{m}$ and (MID TIER-EQUITY) $m$ are dummy variables that equal to 1 if the bank $m$ is ranked from 6 th to 15 th in debt and equity underwriting respectively and 0 otherwise.

In addition the regression also includes borrower industry dummies and calendar year dummies.

At the bottom of each panel we illustrate the economic impact of past lending, debt underwriting and equity underwriting relationships on probability of being chosen as the debt underwriter using the specifications estimated in columns 4 . The first row reports the probability of a non-relationship bank (LOANREL (Number) $\left.{ }^{P u b l i c E q u i t y}=0\right)$ being chosen as the debt underwriter if all other variables held equal to their mean. The second row reports the probability for a relationship bank (LOANREL $(\text { Number })^{\text {PublicEquity }=1)}$ in the same way. Numbers in the parentheses are standard errors which are corrected for heteroscedasticity and clustering (*** Significant at one percent level, ** Significant at five percent level ,* Significant at 10 percent level). 


\begin{tabular}{|c|c|c|c|c|c|c|}
\hline & $(1)$ & $(2)$ & $(3)$ & $(4)$ & $(5)$ & $(6)$ \\
\hline Const. & $\begin{array}{c}-3.64^{* * *} \\
(.007)\end{array}$ & $\begin{array}{c}-3.66^{* * *} \\
(.009)\end{array}$ & $\begin{array}{c}-3.65^{* * *} \\
(.009)\end{array}$ & $\begin{array}{c}-6.78^{* * *} \\
(.38)\end{array}$ & $\begin{array}{c}-6.79^{* * *} \\
(.35)\end{array}$ & $\begin{array}{c}-6.76^{* * *} \\
(.35)\end{array}$ \\
\hline PROCEEDS & $\begin{array}{l}.28^{* * *} \\
(.06)\end{array}$ & $\begin{array}{l}.28^{* * *} \\
(.06)\end{array}$ & $\begin{array}{l}.28^{* * *} \\
(.06)\end{array}$ & $\begin{array}{l}.16 \\
(.21)\end{array}$ & $\begin{array}{l}.31 \\
(.21)\end{array}$ & $\begin{array}{l}.33 \\
(.21)\end{array}$ \\
\hline LOANREL(Dummy) ${ }_{m}^{\text {PublicEquity }}$ & $\begin{array}{l}.33^{* * *} \\
(.11)\end{array}$ & & & $\begin{array}{l}.02 \\
(.36)\end{array}$ & & \\
\hline LOANREL(Number) ${ }_{m}^{\text {PublicEquity }}$ & & $\begin{array}{l}.83^{* * *} \\
(.14)\end{array}$ & & & $\begin{array}{l}.65^{*} \\
(.38)\end{array}$ & \\
\hline LOANREL(Amount) ${ }_{m}^{\text {PublicEquity }}$ & & & $\begin{array}{c}.6^{* * *} \\
(.2)\end{array}$ & & & $\begin{array}{l}.39^{* *} \\
(.18)\end{array}$ \\
\hline$(\text { LOAN MKT SHARE })_{m}$ & $\begin{array}{c}-14.2^{* * *} \\
(3.76)\end{array}$ & $\begin{array}{c}-16.32^{* * *} \\
(3.84)\end{array}$ & $\begin{array}{c}-15.37^{* * *} \\
(3.89)\end{array}$ & $\begin{array}{l}-20.13^{* * *} \\
(6.9)\end{array}$ & $\begin{array}{c}-21.98^{* * *} \\
(6.24)\end{array}$ & $\begin{array}{c}-19.46^{* * *} \\
(6.07)\end{array}$ \\
\hline Lead-DEBTREL(Dummy) ${ }_{m}^{P u b l i c E q u i t y}$ & & & & $\begin{array}{l}1.34^{* * *} \\
(.21)\end{array}$ & & \\
\hline Lead-DEBTREL(Number) ${ }_{m}^{\text {PublicEquity }}$ & & & & & $\begin{array}{c}1.89^{* * *} \\
(.28)\end{array}$ & \\
\hline Lead-DEBTREL(Amount) ${ }_{m}^{\text {PublicEquity }}$ & & & & & & $\begin{array}{l}1.92^{* * *} \\
(.29)\end{array}$ \\
\hline TOP TIER - DEBT & & & & $\begin{array}{c}1.53^{* * *} \\
(.34)\end{array}$ & $\begin{array}{c}1.65^{* * *} \\
(.33)\end{array}$ & $\begin{array}{c}1.62^{* * *} \\
(.33)\end{array}$ \\
\hline MIDDLE TIER - DEBT & & & & $\begin{array}{c}.92^{* * *} \\
(.3)\end{array}$ & $\begin{array}{c}.96^{* * *} \\
(.31)\end{array}$ & $\begin{array}{c}.93^{* * *} \\
(.3)\end{array}$ \\
\hline Lead-EQUITYREL(Dummy) ${ }_{m}^{\text {PublicEquity }}$ & & & & $\begin{array}{l}2.38^{* * *} \\
(.22)\end{array}$ & & \\
\hline Lead-EQUITYREL(Number) ${ }_{m}^{P u b l i c E q u i t y}$ & & & & & $\begin{array}{c}2.97^{* * *} \\
(.27)\end{array}$ & \\
\hline Lead-EQUITYREL(Amount) ${ }_{m}^{\text {PublicEquity }}$ & & & & & & $\begin{array}{c}2.97^{* * *} \\
(.26)\end{array}$ \\
\hline TOP TIER - EQUITY & & & & $\begin{array}{c}2.36^{* * *} \\
(.43)\end{array}$ & $\begin{array}{c}2.54^{* * *} \\
(.43)\end{array}$ & $\begin{array}{c}2.52^{* * *} \\
(.43)\end{array}$ \\
\hline MIDDLE TIER - EQUITY & & & & $\begin{array}{c}2.09^{* * *} \\
(.37)\end{array}$ & $\begin{array}{c}2.14^{* * *} \\
(.37)\end{array}$ & $\begin{array}{c}2.15^{* * *} \\
(.37)\end{array}$ \\
\hline Year Dummies & Yes & Yes & Yes & Yes & Yes & Yes \\
\hline Obs. & 57465 & 57465 & 57465 & 12310 & 12310 & 12310 \\
\hline Pseudo $\mathrm{R}^{2}$ & .006 & .008 & .007 & .47 & .48 & .49 \\
\hline \multicolumn{7}{|c|}{$\begin{array}{l}\text { Impact of past relationships on probability of being chosen as the "lead SEO underwriter" } \\
\text { using the column (4) specification }\end{array}$} \\
\hline & & & & \multicolumn{3}{|c|}{ Probability of being chosen } \\
\hline LOANREL (Dummy) $)_{m}^{\text {PublicEquity }}=0$ & & & & \multicolumn{3}{|c|}{$0.30 \%$} \\
\hline LOANREL $(\text { Dummy })_{m}^{\text {PublicEquity }}=1$ & & & & \multicolumn{3}{|c|}{$0.31 \%$} \\
\hline Increase in probability & & & & \multicolumn{3}{|c|}{$0.01 \%$} \\
\hline 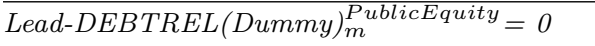 & & & & \multicolumn{3}{|c|}{$0.29 \%$} \\
\hline Lead-DEBTREL (Dummy $)_{m}^{\text {PublicEquity }}=1$ & & & & \multicolumn{3}{|c|}{$1.09 \%$} \\
\hline Increase in probability & & & & \multicolumn{3}{|c|}{$0.80 \%$} \\
\hline 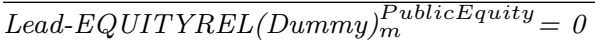 & & & & \multicolumn{3}{|c|}{$0.28 \%$} \\
\hline Lead-EQUITYREL $(\text { Dummy })_{m}^{\text {PublicEquity }}=1$ & & & & \multicolumn{3}{|c|}{$2.95 \%$} \\
\hline Increase in probability & & & & \multicolumn{3}{|c|}{$2.67 \%$} \\
\hline
\end{tabular}




\section{TABLE 8}

\section{Impact of Lending Relationships on Probability of Getting Future Equity Underwriting Business - Initial Public Offerings (IPOs)}

This table provides the logit regression estimates of the following equation.

$$
\begin{aligned}
(\text { RET AIN })_{m}^{\text {Lead-IPO }} & =\beta_{0}+\beta_{1}(\text { PROCEEDS })+\beta_{2}\left(\text { LOANREL }(M)_{m}^{\text {PublicEquity }}\right)+\beta_{4}(\text { LOAN MKT SHARE })_{m} \\
& +\beta_{5}(\text { TOP TIER }-E Q U I T Y)_{m}+\beta_{6}(M I D D L E T I E R-E Q U I T Y)_{m}+\sum \beta_{k}\left(C O N T R O L_{k}\right)
\end{aligned}
$$

For each equity issue, we create a dummy variable (RETAIN) ${ }_{m}^{\text {Lead-IPO }}$ that takes a value of 1 if a bank $m$ was retained as the "lead underwriter" for that IPO equity issue transaction and 0 otherwise. The model is a reduced version of the one estimated for SEOs in Table 7. We dropped the investment banking relationship variables as these are not meaningful for firms conducting an IPO. At the bottom of each panel we illustrate the economic impact of past lending, debt underwriting and equity underwriting relationships on probability of being chosen as the debt underwriter using the specifications estimated in columns 4 . The first row reports the probability of a non-relationship bank (LOANREL(Number) ${ }^{\text {PublicEquity }}=0$ ) being chosen as the debt underwriter if all other variables held equal to their mean. The second row reports the probability for a relationship bank (LOANREL(Number) ${ }^{\text {PublicEquity }=1)}$ in the same way. Numbers in the parentheses are standard errors which are corrected for heteroscedasticity and clustering (***

\begin{tabular}{|c|c|c|c|}
\hline & $(1)$ & $(2)$ & $(3)$ \\
\hline Const. & $\begin{array}{c}-6.25^{* * *} \\
(.22)\end{array}$ & $\begin{array}{c}-6.23^{* * *} \\
(.22)\end{array}$ & $\begin{array}{c}-6.23^{* * *} \\
(.22)\end{array}$ \\
\hline PROCEEDS & $\begin{array}{c}.27^{* * *} \\
(.09)\end{array}$ & $\begin{array}{l}.3^{* * *} \\
(.08)\end{array}$ & $\begin{array}{l}.29^{* * *} \\
(.08)\end{array}$ \\
\hline LOANREL(Dummy) ${ }_{m}^{\text {PublicEquity }}$ & $\begin{array}{l}1.34^{* * *} \\
(.34)\end{array}$ & & \\
\hline LOANREL(Number) ${ }_{m}^{P u b l i c E q u i t y}$ & & $\begin{array}{c}1.52^{* * *} \\
(.39)\end{array}$ & \\
\hline LOANREL(Amount) ${ }_{m}^{\text {PublicEquity }}$ & & & $\begin{array}{c}1.44^{* * *} \\
(.38)\end{array}$ \\
\hline$(\text { LOAN MKT SHARE })_{m}$ & $\begin{array}{c}-11.2^{* *} \\
(5.41)\end{array}$ & $\begin{array}{c}-10.39^{*} \\
(5.41)\end{array}$ & $\begin{array}{c}-10.27^{*} \\
(5.37)\end{array}$ \\
\hline TOP TIER - EQUITY & $\begin{array}{c}4.21^{* * *} \\
(.24)\end{array}$ & $\begin{array}{c}4.18^{* * *} \\
(.24)\end{array}$ & $\begin{array}{c}4.19^{* * *} \\
(.24)\end{array}$ \\
\hline MIDDLE TIER - EQUITY & $\begin{array}{c}2.99^{* * *} \\
(.24)\end{array}$ & $\begin{array}{c}2.97^{* * *} \\
(.24)\end{array}$ & $\begin{array}{c}2.98^{* * *} \\
(.24)\end{array}$ \\
\hline Year Dummies & Yes & Yes & Yes \\
\hline Obs. & 15112 & 15112 & 15112 \\
\hline Pseudo $\mathrm{R}^{2}$ & .24 & .24 & .23 \\
\hline \multicolumn{4}{|c|}{$\begin{array}{l}\text { Impact of past relationships on probability of being chosen as the "lead IPO underwriter" } \\
\text { using the column (1) specification }\end{array}$} \\
\hline & & \multicolumn{2}{|c|}{ Probability of being chosen } \\
\hline LOANREL $(\text { Dummy })_{m}^{\text {PublicEquity }}=0$ & & \multicolumn{2}{|c|}{$0.48 \%$} \\
\hline LOANREL $(\text { Dummy })_{m}^{\text {PublicEquity }}=1$ & & \multicolumn{2}{|c|}{$1.81 \%$} \\
\hline Increase in probability & & \multicolumn{2}{|c|}{$1.33 \%$} \\
\hline
\end{tabular}
Significant at one percent level, ** Significant at five percent level ,* Significant at 10 percent level). 


\section{TABLE 9}

\section{Lending Relationships and Cost of Borrowing.}

This table provides the OLS estimates of the following equation.

$$
\begin{aligned}
A I S D & =\beta_{0}+\beta_{1}\left(\text { LOANREL }(M)^{\text {BankLoans }}\right)+\beta_{2}(\text { LOCATION })+\sum \beta_{i}(\text { LOAN_CHAR }) \\
& +\sum \beta_{j}(\text { BORROWER_CHAR })+\sum \beta_{k}\left(\text { CONTROL }_{k}\right) .
\end{aligned}
$$

The dependant variable AISD is the the coupon spread over LIBOR on the drawn amount plus the annual fee. LOANREL(M) ${ }^{\text {BankLoans }}$ is the measure of relationship strength between the lead bank of the loan facility and the borrower (for loan facilities with multiple lead banks, the maximum LOANREL(M $)^{\text {BankLoans }}$ value among the lead banks is used). It is estimated in 3 different ways-

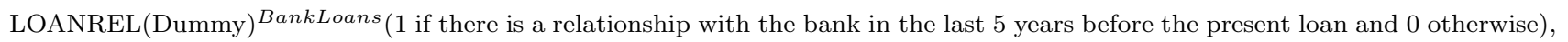

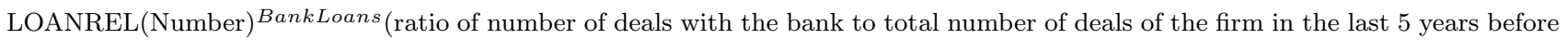
the current loan), LOANREL(Amount) BankLoans (ratio of dollar value of deals with the bank to total dollar value of deals of the firm in the last 5 years before the current loan). LOCATION is a dummy variable that equals 1 if both the lender and the borrower have their respective head offices in the same state. Maturity is length in months between facility activation date and maturity date. LN(Loan Size) is the natural log of the loan facility size. Syndicate, Revolver and Term loan are dummy variables that equal one if the facility has the stated attribute and zero otherwise. LN(Assets) is the natural log of book value of assets of the borrower as reported in the COMPUSTAT. Leverage is the ratio of book value of total debt to book value of assets. Coverage is the ratio of EBITDA to interest expenses. Profitability is the ratio of EBITDA to Sales. Tangibility is the ratio of NPPE to Total Assets. Current Ratio is the ratio of Current Assets to Current Liabilities. Market to book is the ratio of (Book value of assets-Book value of equity + market value of equity) divided by book value of assets. Numbers in the parentheses are standard errors which are corrected for heteroscedasticity $\left(* * *\right.$ Significant at one percent level, ** Significant at five percent level , ${ }^{*}$ Significant at 10 percent level). 


\begin{tabular}{|c|c|c|c|c|c|c|}
\hline & $(1)$ & $(2)$ & $(3)$ & $(4)$ & $(5)$ & $(6)$ \\
\hline Const. & $\begin{array}{c}449.59^{* * *} \\
(30.63)\end{array}$ & $\begin{array}{c}422.06^{* * *} \\
(30.55)\end{array}$ & $\begin{array}{c}450.11^{* * *} \\
(30.73)\end{array}$ & $\begin{array}{c}421.86^{* * *} \\
(30.62)\end{array}$ & $\begin{array}{c}449.83^{* * *} \\
(30.71)\end{array}$ & $\begin{array}{c}421.58^{* * *} \\
(30.6)\end{array}$ \\
\hline LOANREL(Dummy) BankLoans & $\begin{array}{c}-9.54^{* * *} \\
(2.43)\end{array}$ & $\begin{array}{c}-7.39^{* * *} \\
(2.39)\end{array}$ & & & & \\
\hline LOANREL(Number) BankLoans & & & $\begin{array}{c}-6.85^{* * *} \\
(2.4)\end{array}$ & $\begin{array}{c}-4.95^{* *} \\
(2.38)\end{array}$ & & \\
\hline LOANREL(Amount) BankLoans & & & & & $\begin{array}{c}-6.48^{* * *} \\
(2.4)\end{array}$ & $\begin{array}{l}-4.48^{*} \\
(2.37)\end{array}$ \\
\hline (LOCATION) & & $\begin{array}{c}20.64^{* * *} \\
(2.55)\end{array}$ & & $\begin{array}{c}21.02^{* * *} \\
(2.56)\end{array}$ & & $\begin{array}{c}21.03^{* * *} \\
(2.55)\end{array}$ \\
\hline Maturity & $\begin{array}{l}-0.001 \\
(.009)\end{array}$ & $\begin{array}{l}-.008 \\
(.008)\end{array}$ & $\begin{array}{r}-0.001 \\
(.009)\end{array}$ & $\begin{array}{l}-.008 \\
(.008)\end{array}$ & $\begin{array}{l}-0.001 \\
(.009)\end{array}$ & $\begin{array}{l}-.008 \\
(.008)\end{array}$ \\
\hline LN(Loan Size) & $\begin{array}{c}-14.01^{* * *} \\
(1.22)\end{array}$ & $\begin{array}{c}-13^{* * *} \\
(1.23)\end{array}$ & $\begin{array}{c}-14.13^{* * *} \\
(1.22)\end{array}$ & $\begin{array}{c}-13.09^{* * *} \\
(1.23)\end{array}$ & $\begin{array}{c}-14.12^{* * *} \\
(1.23)\end{array}$ & $\begin{array}{c}-13.09^{* * *} \\
(1.23)\end{array}$ \\
\hline Syndicate & $\begin{array}{c}-15.86^{* * *} \\
(4.08)\end{array}$ & $\begin{array}{c}-13.08^{* * *} \\
(4.09)\end{array}$ & $\begin{array}{c}-16.19^{* * *} \\
(4.08)\end{array}$ & $\begin{array}{c}-13.3^{* * *} \\
(4.09)\end{array}$ & $\begin{array}{c}-16.16^{* * *} \\
(4.08)\end{array}$ & $\begin{array}{c}-13.29^{* * *} \\
(4.09)\end{array}$ \\
\hline Revolver & $\begin{array}{c}.63 \\
(3.05)\end{array}$ & $\begin{array}{c}1.01 \\
(3.04)\end{array}$ & $\begin{array}{c}.7 \\
(3.05)\end{array}$ & $\begin{array}{c}1.07 \\
(3.04)\end{array}$ & $\begin{array}{c}.67 \\
(3.05)\end{array}$ & $\begin{array}{c}1.05 \\
(3.04)\end{array}$ \\
\hline Termloan & $\begin{array}{c}40.14^{* * *} \\
(3.72)\end{array}$ & $\begin{array}{c}40.92^{* * *} \\
(3.7)\end{array}$ & $\begin{array}{c}40.07^{* * *} \\
(3.72)\end{array}$ & $\begin{array}{c}40.87^{* * *} \\
(3.7)\end{array}$ & $\begin{array}{c}40.04^{* * *} \\
(3.73)\end{array}$ & $\begin{array}{c}40.84^{* * *} \\
(3.7)\end{array}$ \\
\hline LN(Assets) & $\begin{array}{c}-20.71^{* * *} \\
(1.03)\end{array}$ & $\begin{array}{c}-20.08^{* * *} \\
(1.03)\end{array}$ & $\begin{array}{c}-20.9^{* * *} \\
(1.03)\end{array}$ & $\begin{array}{c}-20.22^{* * *} \\
(1.03)\end{array}$ & $\begin{array}{c}-20.88^{* * *} \\
(1.03)\end{array}$ & $\begin{array}{c}-20.2^{* * *} \\
(1.03)\end{array}$ \\
\hline $\mathrm{LN}(1+$ coverage $)$ & $\begin{array}{c}-25.63^{* * *} \\
(1.41)\end{array}$ & $\begin{array}{c}-25.34^{* * *} \\
(1.4)\end{array}$ & $\begin{array}{c}-25.68^{* * *} \\
(1.41)\end{array}$ & $\begin{array}{c}-25.39^{* * *} \\
(1.4)\end{array}$ & $\begin{array}{c}-25.71^{* * *} \\
(1.41)\end{array}$ & $\begin{array}{c}-25.41^{* * *} \\
\quad(1.4)\end{array}$ \\
\hline Leverage & $\begin{array}{c}28.01^{* * *} \\
(6.08)\end{array}$ & $\begin{array}{c}31.15^{* * *} \\
(6.07)\end{array}$ & $\begin{array}{c}27.54^{* * *} \\
(6.07)\end{array}$ & $\begin{array}{c}30.81^{* * *} \\
(6.06)\end{array}$ & $\begin{array}{c}27.5^{* * *} \\
(6.07)\end{array}$ & $\begin{array}{c}30.76^{* * *} \\
(6.06)\end{array}$ \\
\hline Profitability & $\begin{array}{c}-28.59^{* * *} \\
(11.05)\end{array}$ & $\begin{array}{c}-27.73^{* *} \\
(11)\end{array}$ & $\begin{array}{c}-28.61^{* * *} \\
(11.06)\end{array}$ & $\begin{array}{c}-27.75^{* *} \\
(11.01)\end{array}$ & $\begin{array}{c}-28.61^{* * *} \\
(11.06)\end{array}$ & $\begin{array}{c}-27.76^{* *} \\
(11.01)\end{array}$ \\
\hline Tangibility & $\begin{array}{c}-18.8^{* * *} \\
(5.03)\end{array}$ & $\begin{array}{c}-17.73^{* * *} \\
(5.02)\end{array}$ & $\begin{array}{c}-18.86^{* * *} \\
(5.03)\end{array}$ & $\begin{array}{c}-17.75^{* * *} \\
\quad(5.02)\end{array}$ & $\begin{array}{c}-18.83^{* * *} \\
(5.03)\end{array}$ & $\begin{array}{c}-17.74^{* * *} \\
(5.02)\end{array}$ \\
\hline Current Ratio & $\begin{array}{c}-1.36^{*} \\
(.75)\end{array}$ & $\begin{array}{c}-1.5^{* *} \\
(.74)\end{array}$ & $\begin{array}{c}-1.38^{*} \\
(.75)\end{array}$ & $\begin{array}{c}-1.52^{* *} \\
(.74)\end{array}$ & $\begin{array}{c}-1.37^{*} \\
(.75)\end{array}$ & $\begin{array}{c}-1.51^{* *} \\
(.74)\end{array}$ \\
\hline Market to Book & $\begin{array}{c}-3.82^{* * *} \\
(1.17)\end{array}$ & $\begin{array}{c}-3.67^{* * *} \\
(1.15)\end{array}$ & $\begin{array}{c}-3.81^{* * *} \\
(1.17)\end{array}$ & $\begin{array}{c}-3.67^{* * *} \\
(1.16)\end{array}$ & $\begin{array}{c}-3.83^{* * *} \\
(1.17)\end{array}$ & $\begin{array}{c}-3.69^{* * *} \\
(1.16)\end{array}$ \\
\hline Industry Dummies & Yes & Yes & Yes & Yes & Yes & Yes \\
\hline Year Dummies & Yes & Yes & Yes & Yes & Yes & Yes \\
\hline Loan Purpose Dummies & Yes & Yes & Yes & Yes & Yes & Yes \\
\hline Obs. & 9709 & 9709 & 9709 & 9709 & 9709 & 9709 \\
\hline$R^{2}$ & .49 & .49 & .49 & .49 & .49 & .49 \\
\hline
\end{tabular}




\section{TABLE 10}

\section{Impact of Lending Relationships on Fees Paid For Debt Underwriting Business}

This table provides the OLS regression (corrected for heteroscedasticity) estimates of the following equation.

$$
\begin{aligned}
(\text { FEE })^{\text {PublicDebt }} & =\beta_{0}+\beta_{1}\left(\text { LOANREL }(M)^{\text {PublicDebt }}\right)+\beta_{2}\left(\text { Lead }- \text { DEBTREL }(M)^{\text {PublicDebt }}\right) \\
& +\beta_{3}\left(\text { Lead }- \text { EQUITYREL }(M)^{\text {PublicDebt }}\right)+\beta_{4}(\text { LOAN MKT SHARE }) \\
& +\beta_{5}(\text { TOP TIER }-D E B T)+\beta_{6}(M I D T I E R-D E B T)+\beta_{7}(T O P \text { TIER }- \text { EQUITY }) \\
& +\beta_{8}(M I D T I E R-E Q U I T Y)+\beta_{9}(1 / \text { PROCEEDS })+\beta_{10}(\text { PROCEEDS } / M \text { KTCAP }) \\
& +\beta_{11}(\text { DEBTVOLUME })+\sum \beta_{S \& P}(R A T I N G)_{S \& P}+\sum \beta_{k}\left(C O N T R O L_{k}\right) .
\end{aligned}
$$

(FEE) ${ }^{\text {PublicDebt }}$ is the gross spread calculated as ratio of fees charged divided by the total proceeds raised from the debt issue expressed in basis points. We estimate relationships across 3 markets: the bank loan market, the debt underwriting market and the equity underwriting market. LOANREL(Dummy) PublicDebt $(1$ if there is a loan relationship with the underwriting bank in the last 5 years before the present equity underwriting transaction and 0 otherwise), LOANREL(Number) ${ }^{\text {PublicDebt }}$ (ratio of number of loan deals with the underwriting bank to total number of loan deals of the firm in the last 5 years before the current equity underwriting transaction), LOANREL(Amount) PublicDebt (ratio of dollar value of loan deals with the underwriting bank to total dollar value of loan deals of the firm in the last 5 years before the current equity underwriting transaction). For issues in which multiple underwriters have past lending relationships, the highest value is used. Lead-DEBTREL(Dummy) $)^{\text {PublicDebt }}(1$ if there is a debt underwriting relationship in lead underwriter capacity with the underwriter (commercial bank or investment bank) in the last 5 years before the present debt underwriting transaction and 0 otherwise), Lead-DEBTREL(Number) ${ }^{\text {PublicDebt }}$ (ratio of number of debt underwriting deals in lead underwriter capacity with the underwriter (commercial bank or investment bank) to total number of debt underwriting deals of the firm in the last 5 years before the current debt underwriting transaction), Lead-

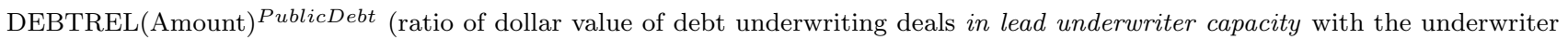
(commercial bank or investment bank) to total dollar value of debt underwriting deals of the firm in the last 5 years before the current debt underwriting transaction). For issues in which multiple underwriters have past debt underwriting relationships, the highest value is used. Lead-EQUITYREL(Dummy) ${ }^{\text {PublicDebt }}(1$ if there is an equity underwriting relationship with the underwriter in lead underwriter capacity (commercial bank or investment bank) in the last 5 years before the present debt underwriting transaction

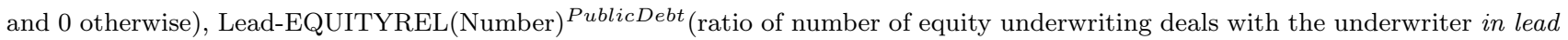
underwriter capacity (commercial bank or investment bank) to total number of equity underwriting deals of the firm in the last 5 years before the current debt underwriting transaction), Lead -EQUITYREL(Amount) ${ }^{\text {PublicDebt }}$ (ratio of dollar value of equity underwriting deals with the underwriter in lead underwriter capacity (commercial bank or investment bank) to total dollar value of equity underwriting deals of the firm in the last 5 years before the current debt underwriting transaction). For issues in which multiple underwriters have past equity underwriting relationships, the highest value is used. (LOAN MKT SHARE) is the highest loan market share (across all underwriters of the current issue) in the year before the current debt underwriting transaction. Similar calculations are done to estimate market shares for debt underwriting and equity underwriting market. (TOP TIER-DEBT) and (TOP TIER-EQUITY) are dummy variables that equal to 1 if the highest rank across underwriters of current issue lies in the top 5 debt and equity underwriters respectively and 0 otherwise. (MID TIER-DEBT) $m$ and (MID TIER-EQUITY) $m$ are dummy variables that equal to 1 if the highest rank of across underwriters of current issue lies between 6th to 15th in debt and equity underwriting respectively and 0 otherwise. PROCEEDS is the amount raised in $\$$ millions for the equity underwriting transaction (reported coefficient has been divided by 1000), MKTCAP is the market value of equity of the issuer as of the time of offering., DEBTVOLUME is the aggregate value of all debt in $\$$ millions issued by industrial firms over the the prior three month period as reported by SDC (reported coefficient has been divided by 1000). In addition to the variables reported, the regression also includes dummy variables for the bond rating classes. Numbers in the parentheses are standard errors which are corrected for heteroscedasticity (*** Significant at one percent level, ${ }^{* *}$ Significant at five percent level,${ }^{*}$ Significant at 10 percent level). 


\begin{tabular}{|c|c|c|c|c|c|c|}
\hline & $(1)$ & $(2)$ & $(3)$ & $(4)$ & $(5)$ & $(6)$ \\
\hline Const. & $\begin{array}{c}116.93^{* * *} \\
(14.65)\end{array}$ & $\begin{array}{c}117.24^{* * *} \\
(14.65)\end{array}$ & $\begin{array}{c}117.32^{* * *} \\
(14.66)\end{array}$ & $\begin{array}{c}163.56^{* * *} \\
(26.05)\end{array}$ & $\begin{array}{c}161.63^{* * *} \\
(26.26)\end{array}$ & $\begin{array}{c}162.01^{* * *} \\
(26.27)\end{array}$ \\
\hline LOANREL(Dummy)) PublicDebt & $\begin{array}{c}10.09^{* * *} \\
(1.87)\end{array}$ & & & $\begin{array}{c}12.03^{* * *} \\
(3.38)\end{array}$ & & \\
\hline LOANREL(Number)) PublicDebt & & $\begin{array}{c}12.53^{* * *} \\
(2.08)\end{array}$ & & & $\begin{array}{c}16.11^{* * *} \\
(4.12)\end{array}$ & \\
\hline LOANREL(Amount)) PublicDebt & & & $\begin{array}{c}12.43^{* * *} \\
(2)\end{array}$ & & & $\begin{array}{c}15.83^{* * *} \\
(3.77)\end{array}$ \\
\hline LOAN MKT SHARE & $\begin{array}{l}-56.37 \\
(43.17)\end{array}$ & $\begin{array}{l}-57.77 \\
(43.54)\end{array}$ & $\begin{array}{c}-60.67 \\
(43.33)\end{array}$ & $\begin{array}{l}-62.26 \\
(92.18)\end{array}$ & $\begin{array}{l}-78.6 \\
(94.32)\end{array}$ & $\begin{array}{l}-80.38 \\
(92.6)\end{array}$ \\
\hline TOP TIER - DEBT & & & & $\begin{array}{c}-14.81^{*} \\
(8.45)\end{array}$ & $\begin{array}{l}-14.5^{*} \\
(8.51)\end{array}$ & $\begin{array}{c}-15.46^{*} \\
(8.42)\end{array}$ \\
\hline MIDDLE TIER - DEBT & & & & $\begin{array}{r}-9.22 \\
(7.9)\end{array}$ & $\begin{array}{c}-7.8 \\
(7.96)\end{array}$ & $\begin{array}{l}-8.53 \\
(7.89)\end{array}$ \\
\hline Lead-DEBTREL(Dummy) PublicDebt & & & & $\begin{array}{l}-4.01 \\
(3.18)\end{array}$ & & \\
\hline Lead-DEBTREL(Number) ${ }^{\text {PublicDebt }}$ & & & & & $\begin{array}{c}4.49 \\
(3.96)\end{array}$ & \\
\hline Lead-DEBTREL(Amount) ${ }^{\text {PublicDebt }}$ & & & & & & $\begin{array}{c}6.42 \\
(3.92)\end{array}$ \\
\hline TOP TIER - EQUITY & & & & $\begin{array}{c}15.05^{* *} \\
(6.6)\end{array}$ & $\begin{array}{c}14.94^{* *} \\
(6.5)\end{array}$ & $\begin{array}{c}14.62^{* *} \\
(6.44)\end{array}$ \\
\hline MIDDLE TIER - EQUITY & & & & $\begin{array}{c}12.09^{* *} \\
(5.33)\end{array}$ & $\begin{array}{c}10.65^{* *} \\
(5.28)\end{array}$ & $\begin{array}{l}10.13^{*} \\
(5.27)\end{array}$ \\
\hline Lead-EQUITYREL(Dummy) PublicDebt & & & & $\begin{array}{c}4.59 \\
(2.99)\end{array}$ & & \\
\hline Lead-EQUITYREL(Number) ${ }^{\text {PublicDebt }}$ & & & & & $\begin{array}{c}.34 \\
(3.19)\end{array}$ & \\
\hline Lead-EQUITYREL(Amount) PublicDebt & & & & & & $\begin{array}{c}-.05 \\
(3.28)\end{array}$ \\
\hline 1/(PROCEEDS $)$ & $\begin{array}{l}-13.6 \\
(14.31)\end{array}$ & $\begin{array}{l}-13.32 \\
(14.14)\end{array}$ & $\begin{array}{l}-12.81 \\
(13.97)\end{array}$ & $\begin{array}{c}-1.06 \\
(11.19)\end{array}$ & $\begin{array}{c}-1.64 \\
(11.31)\end{array}$ & $\begin{array}{c}-.86 \\
(10.94)\end{array}$ \\
\hline (MKTCAP)/(PROCEEDS) & $\begin{array}{l}.03 \\
(.04)\end{array}$ & $\begin{array}{l}.02 \\
(.04)\end{array}$ & $\begin{array}{l}.02 \\
(.04)\end{array}$ & $\begin{array}{c}.03 \\
(.02)\end{array}$ & $\begin{array}{c}.03 \\
(.02)\end{array}$ & $\begin{array}{c}.03 \\
(.02)\end{array}$ \\
\hline DEBTVOLUME & $\begin{array}{l}.59^{* *} \\
(.28)\end{array}$ & $\begin{array}{l}.58^{* *} \\
(.28)\end{array}$ & $\begin{array}{l}.59^{* *} \\
(.28)\end{array}$ & $\begin{array}{l}.66 \\
(.5)\end{array}$ & $\begin{array}{l}.62 \\
(.5)\end{array}$ & $\begin{array}{l}.64 \\
(.5)\end{array}$ \\
\hline Bond Rating Dummies & Yes & Yes & Yes & Yes & Yes & Yes \\
\hline Year Dummies & Yes & Yes & Yes & Yes & Yes & Yes \\
\hline Obs. & 2770 & 2770 & 2770 & 959 & 959 & 959 \\
\hline$R^{2}$ & .66 & .66 & .66 & .69 & .69 & .69 \\
\hline
\end{tabular}




\section{TABLE 11}

\section{Impact of Lending Relationships on Fees Paid For Equity Underwriting Business}

This table provides the OLS regression (corrected for heteroscedasticity and clustering) estimates of spreads charged by equity underwriters. Panel A reports the results for Seasoned Equity Offerings (SEOs) and Panel B provides the estimates for Initial Public Offerings (IPOs). The two models estimated are:

$$
\begin{aligned}
& (F E E)^{S E O}=\beta_{0}+\beta_{1}\left(L O A N R E L(M)^{\text {PublicEquity }}\right)+\beta_{2}\left(\text { Lead }-E Q U I T Y R E L(M)^{\text {PublicEquity }}\right) \\
& +\beta_{3}\left(\text { Lead }- \text { DEBTREL }(M)^{\text {PublicEquity }}\right)+\beta_{4}(L O A N M K T S H A R E)+\beta_{5}(T O P \text { TIER }-D E B T) \\
& +\beta_{6}(M I D T I E R-D E B T)+\beta_{7}(T O P T I E R-E Q U I T Y)+\beta_{8}(M I D T I E R-E Q U I T Y)+\beta_{9}(1 / P R O C E E D S) \\
& +\beta_{10}(P R O C E E D S / M K T C A P)+\beta_{11}(E Q U I T Y V O L U M E)+\beta_{12}(\text { VOLATILITY })+\sum \beta_{k}(C O N T R O L)_{k} .
\end{aligned}
$$

$$
\begin{aligned}
(F E E)^{I P O} & =\beta_{0}+\beta_{1}\left(L O A N R E L(M)^{\text {PublicEquity }}\right)+\beta_{2}(L O A N \text { MKT SHARE })+\beta_{3}(\text { TOP TIER }- \text { EQUITY }) \\
& +\beta_{4}(\text { MID TIER }-E Q U I T Y)+\beta_{5}(1 / \text { PROCEEDS })+\beta_{6}(E Q U I T Y V O L U M E)+\sum \beta_{k}(C O N T R O L)_{k}
\end{aligned}
$$

(FEE) is the gross spread calculated as ratio of fees charged divided by the total proceeds raised from the equity issue expressed in basis points. We estimate relationships across 3 markets: the bank loan market, the debt underwriting market and the equity underwriting market. LOANREL(Dummy) PublicEquity (1 if there is a loan relationship with the underwriting bank in the last 5 years before the present equity underwriting transaction and 0 otherwise), LOANREL(Number) ${ }^{\text {PublicEquity (ratio of number }}$ of loan deals with the underwriting bank to total number of loan deals of the firm in the last 5 years before the current equity underwriting transaction), LOANREL(Amount) PublicEquity (ratio of dollar value of loan deals with the underwriting bank to total dollar value of loan deals of the firm in the last 5 years before the current equity underwriting transaction). For issues in which multiple underwriters have past lending relationships, the highest value is used. Lead-DEBTREL(Dummy) PublicEquity $(1$ if there is a debt underwriting relationship in lead underwriter capacity with the underwriter (commercial bank or investment bank) in the last 5 years before the present debt underwriting transaction and 0 otherwise), Lead-DEBTREL(Number) ${ }^{\text {PublicEquity }(\text { ratio of }}$ number of debt underwriting deals in lead underwriter capacity with the underwriter (commercial bank or investment bank) to total number of debt underwriting deals of the firm in the last 5 years before the current debt underwriting transaction), LeadDEBTREL(Amount) PublicEquity (ratio of dollar value of debt underwriting deals in lead underwriter capacity with the underwriter (commercial bank or investment bank) to total dollar value of debt underwriting deals of the firm in the last 5 years before the current debt underwriting transaction). For issues in which multiple underwriters have past debt underwriting relationships, the highest value is used. Lead-EQUITYREL(Dummy) ${ }^{\text {PublicEquity }}(1$ if there is an equity underwriting relationship with the underwriter in lead underwriter capacity (commercial bank or investment bank) in the last 5 years before the present debt underwriting transaction

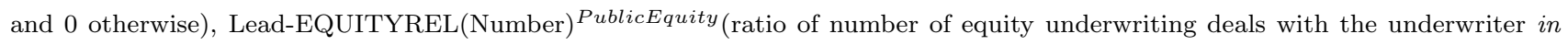
lead underwriter capacity (commercial bank or investment bank) to total number of equity underwriting deals of the firm in the

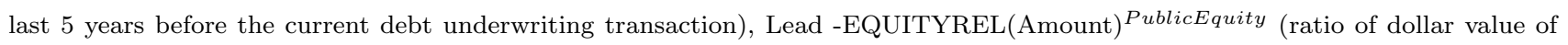
equity underwriting deals with the underwriter in lead underwriter capacity (commercial bank or investment bank) to total dollar value of equity underwriting deals of the firm in the last 5 years before the current debt underwriting transaction). For issues in which multiple underwriters have past equity underwriting relationships, the highest value is used. (LOAN MKT SHARE) is the highest loan market share (across all underwriters of the current issue) in the year before the current equity underwriting transaction. Similar calculations are done to estimate market shares for debt underwriting and equity underwriting market. (TOP TIER-DEBT) and (TOP TIER-EQUITY) are dummy variables that equal to 1 if the highest rank across all underwriters of current issue lies in the top 5 debt and equity underwriters respectively and 0 otherwise. (MID TIER-DEBT) and (MID TIER-EQUITY) are dummy variables that equal to 1 if the highest rank of across underwriters of current issue lies between 6 th to 15 th in debt and equity underwriting respectively and 0 otherwise. PROCEEDS is the amount raised in millions (reported coefficient has been divided by 1000), MKTCAP is the market value of equity of the issuer as of the time of offering. EQUITYVOLUME is the aggregate value of all equity issued by industrial firms over the prior three month period as reported by SDC (reported coefficient has been divided by 1000). VOLATILITY is the daily standard deviation of the returns on common stock of the issuer and is estimated over the 220 trading day period ending 40 days before the offering date. Numbers in the parentheses are standard errors which are corrected for heteroscedasticity (*** Significant at one percent level, ${ }^{* *}$ Significant at five percent level ${ }^{*}$ Significant at 10 percent level). 


\begin{tabular}{|c|c|c|c|c|c|c|}
\hline & $(1)$ & $(2)$ & $(3)$ & $(4)$ & $(5)$ & (6) \\
\hline Const. & $\begin{array}{c}365.43^{* * *} \\
(14.76)\end{array}$ & $\begin{array}{c}363.74^{* * *} \\
(14.85)\end{array}$ & $\begin{array}{c}363.95^{* * *} \\
(14.86)\end{array}$ & $\begin{array}{c}276.87^{* * *} \\
(49.51)\end{array}$ & $\begin{array}{c}260.62^{* * *} \\
(47.23)\end{array}$ & $\begin{array}{c}261.22^{* * *} \\
(47.5)\end{array}$ \\
\hline LOANREL(Dummy)) PublicEquity & $\begin{array}{c}-25.16^{* * *} \\
(7.68)\end{array}$ & & & $\begin{array}{c}10.82 \\
(14.38)\end{array}$ & & \\
\hline LOANREL(Number)) PublicEquity & & $\begin{array}{c}-20.34^{* *} \\
(8.55)\end{array}$ & & & $\begin{array}{c}7.36 \\
(16.16)\end{array}$ & \\
\hline LOANREL(Amount)) PublicEquity & & & $\begin{array}{c}-19.84^{* *} \\
(8.18)\end{array}$ & & & $\begin{array}{c}8.62 \\
(15.21)\end{array}$ \\
\hline LOAN MKT SHARE & $\begin{array}{c}-15.14 \\
(210.11)\end{array}$ & $\begin{array}{c}-73.5 \\
(214.07)\end{array}$ & $\begin{array}{c}-66.21 \\
(213.78)\end{array}$ & $\begin{array}{c}27.47 \\
(359.6)\end{array}$ & $\begin{array}{c}67.22 \\
(365.92)\end{array}$ & $\begin{array}{c}54.51 \\
(374.32)\end{array}$ \\
\hline TOP TIER - EQUITY & & & & $\begin{array}{l}-17.93 \\
(43.23)\end{array}$ & $\begin{array}{l}-20.18 \\
(41.56)\end{array}$ & $\begin{array}{c}-23.81 \\
(42.32)\end{array}$ \\
\hline MIDDLE TIER - EQUITY & & & & $\begin{array}{l}-21.08 \\
(37.93)\end{array}$ & $\begin{array}{l}-22.51 \\
(36.96)\end{array}$ & $\begin{array}{l}-25.16 \\
(37.4)\end{array}$ \\
\hline Lead-EQUITYREL(Dummy) $)^{\text {PublicEquity }}$ & & & & $\begin{array}{l}-22.54 \\
(17.24)\end{array}$ & & \\
\hline Lead-EQUITYREL(Number) ${ }^{\text {PublicEquity }}$ & & & & & $\begin{array}{c}-23.97 \\
(19.63)\end{array}$ & \\
\hline Lead-EQUITYREL(Amount) ${ }^{\text {PublicEquity }}$ & & & & & & $\begin{array}{c}-17.51 \\
(18.94)\end{array}$ \\
\hline TOP TIER - DEBT & & & & $\begin{array}{c}10.99 \\
(26.12)\end{array}$ & $\begin{array}{l}14.96 \\
(25.14)\end{array}$ & $\begin{array}{c}16.22 \\
(25.19)\end{array}$ \\
\hline MIDDLE TIER - DEBT & & & & $\begin{array}{c}20.09 \\
(23.25)\end{array}$ & $\begin{array}{c}24.75 \\
(23.02)\end{array}$ & $\begin{array}{c}25.81 \\
(22.87)\end{array}$ \\
\hline Lead-DEBTREL(Dummy) PublicEquity & & & & $\begin{array}{c}-.61 \\
(18.26)\end{array}$ & & \\
\hline Lead-DEBTREL(Number) $)^{\text {PublicEquity }}$ & & & & & $\begin{array}{c}-9.45 \\
(21.25)\end{array}$ & \\
\hline Lead-DEBTREL(Amount) PublicEquity & & & & & & $\begin{array}{c}-11.11 \\
(19.98)\end{array}$ \\
\hline 1/(PROCCEDS $)$ & $\begin{array}{c}.64 \\
(.39)\end{array}$ & $\begin{array}{l}.66^{*} \\
(.4)\end{array}$ & $\begin{array}{l}.66^{*} \\
(.4)\end{array}$ & $\begin{array}{c}4.63^{* * *} \\
(1.24)\end{array}$ & $\begin{array}{c}4.63^{* * *} \\
(1.21)\end{array}$ & $\begin{array}{c}4.65^{* * *} \\
(1.22)\end{array}$ \\
\hline (MKTCAP)/(PROCEEDS) & $\begin{array}{c}.47 \\
(.34)\end{array}$ & $\begin{array}{c}.48 \\
(.34)\end{array}$ & $\begin{array}{c}.47 \\
(.34)\end{array}$ & $\begin{array}{c}.57 \\
(.38)\end{array}$ & $\begin{array}{c}.59 \\
(.38)\end{array}$ & $\begin{array}{c}.52 \\
(.38)\end{array}$ \\
\hline VOLATILITY & $\begin{array}{c}1.82^{* * *} \\
(.19)\end{array}$ & $\begin{array}{c}1.86^{* * *} \\
(.18)\end{array}$ & $\begin{array}{c}1.85^{* * *} \\
(.19)\end{array}$ & $\begin{array}{c}1.51^{* * *} \\
(.43)\end{array}$ & $\begin{array}{c}1.56^{* * *} \\
(.45)\end{array}$ & $\begin{array}{c}1.56^{* * *} \\
(.45)\end{array}$ \\
\hline EQUITYVOLUME & $\begin{array}{l}1.46^{*} \\
(.87)\end{array}$ & $\begin{array}{l}1.51^{*} \\
(.87)\end{array}$ & $\begin{array}{l}1.5^{*} \\
(.87)\end{array}$ & $\begin{array}{c}1.9 \\
(2.35)\end{array}$ & $\begin{array}{c}2.09 \\
(2.43)\end{array}$ & $\begin{array}{c}2.03 \\
(2.43)\end{array}$ \\
\hline Year Dummies & Yes & Yes & Yes & Yes & Yes & Yes \\
\hline Obs. & 884 & 884 & 884 & 198 & 198 & 198 \\
\hline$R^{2}$ & .33 & .32 & .32 & .42 & .42 & .42 \\
\hline
\end{tabular}




\begin{tabular}{|c|c|c|c|}
\hline & (1) & $(2)$ & (3) \\
\hline Const. & $\begin{array}{c}521.72^{* * *} \\
(12.59)\end{array}$ & $\begin{array}{c}521.12^{* * *} \\
(12.62)\end{array}$ & $\begin{array}{c}521.37^{* * *} \\
(12.61)\end{array}$ \\
\hline LOANREL(Dummy)) PublicEquity & $\begin{array}{c}-26.12^{* * *} \\
(9.36)\end{array}$ & & \\
\hline LOANREL(Number)) PublicEquity & & $\begin{array}{c}-19.62^{* *} \\
(9.59)\end{array}$ & \\
\hline LOANREL(Amount)) PublicEquity & & & $\begin{array}{c}-21.43^{* *} \\
(9.49)\end{array}$ \\
\hline LOAN MKT SHARE & $\begin{array}{l}-4.87 \\
(3.37)\end{array}$ & $\begin{array}{l}-5.35 \\
(3.48)\end{array}$ & $\begin{array}{l}-5.31 \\
(3.44)\end{array}$ \\
\hline TOP TIER - EQUITY & $\begin{array}{l}-7.07 \\
(8.86)\end{array}$ & $\begin{array}{l}-7.04 \\
(8.82)\end{array}$ & $\begin{array}{l}-7.21 \\
(8.82)\end{array}$ \\
\hline MIDDLE TIER - EQUITY & $\begin{array}{c}.38 \\
(9.81)\end{array}$ & $\begin{array}{c}1.26 \\
(9.69)\end{array}$ & $\begin{array}{c}.84 \\
(9.77)\end{array}$ \\
\hline 1/(PROCCEDS $)$ & $\begin{array}{c}3.1^{* * *} \\
(.6)\end{array}$ & $\begin{array}{c}3.17^{* * *} \\
(.61)\end{array}$ & $\begin{array}{c}3.15^{* * *} \\
(.61)\end{array}$ \\
\hline EQUITYVOLUME & $\begin{array}{l}-1.29 \\
(1.51)\end{array}$ & $\begin{array}{l}-1.49 \\
(1.52)\end{array}$ & $\begin{array}{l}-1.42 \\
(1.51)\end{array}$ \\
\hline Year Dummies & Yes & Yes & Yes \\
\hline Obs. & 278 & 278 & 278 \\
\hline$R^{2}$ & .4 & .39 & .39 \\
\hline
\end{tabular}


Figure 1: Construction of Relationship Measures in Bank Loan Market Construction of lending relationship measure for a bank $m$ assuming current loan transaction takes place on 1/1/1999

LOANREL $(M)_{m}^{\text {BankLoans }}$

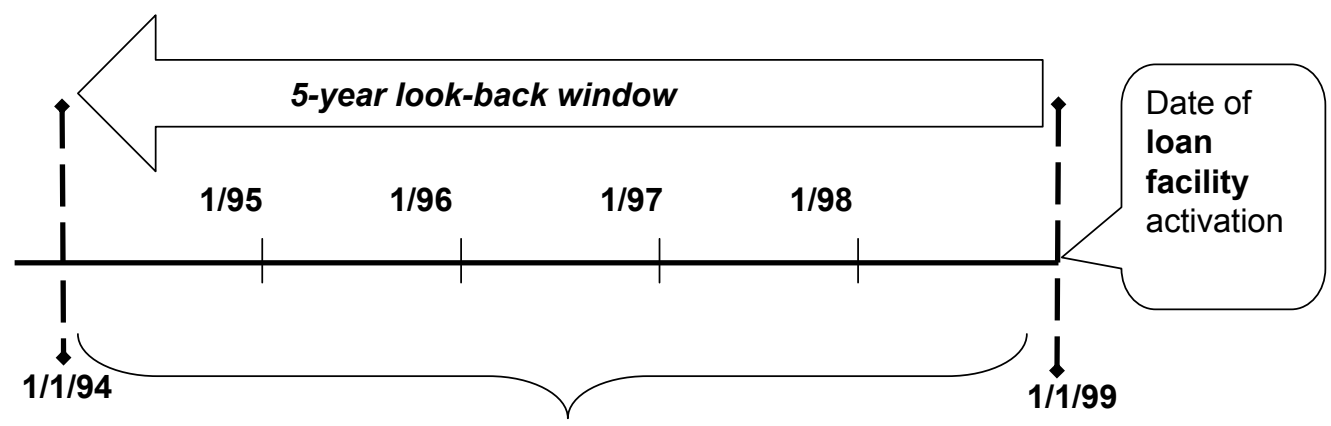

Illustration:

- $\quad$ Search if bank $m$ lead bank on any loans during this period. If $m$ was the lead bank on any loan LOANREL(Dummy) $\underset{m}{\text { BankLoans }}=1$ 
Figure 2: Construction of Relationship Measures in Public Debt Underwriting Market

Construction of lending and investment banking relationship measure for a bank $m$ assuming current public debt issue takes place on 1/1/1999
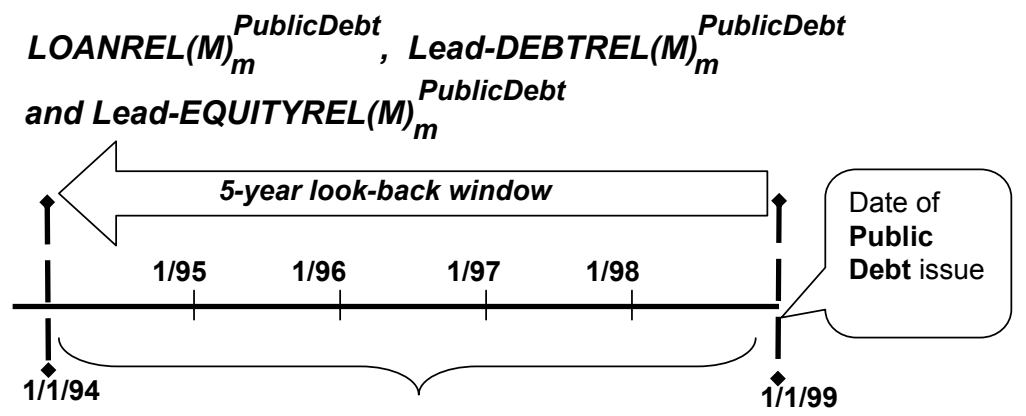

Illustrations:

- Search if bank $m$ lead bank on any loans during this period. If $m$ was the lead bank on any loan, then LOANREL(Dummy) ${ }_{m}^{\text {Pub }}$

- Search if bank $m$ lead underwriter on any public debt issue during this period. If $m$ was the lead underwriter on any debt issue, then Lead-DEBTREL(Dummy) ${ }_{m}^{\text {PublicDebt }=1}$

- Search if bank $m$ lead underwriter on any public equity issue during this period. If $m$ was the lead underwriter on any equity issue, then
Lead-EQUITYREL(Dummy) ${ }_{m}^{\text {PublicDebt }}=1$ 
Figure 3: Construction of Relationship Measures in Public Equity Underwriting Market

Construction of lending and investment banking relationship measure for a bank $m$ assuming current public equity issue takes place on 1/1/1999

LOANREL $(M) \underset{m}{\text { PublicEquity }} \stackrel{\text { Lead-DEBTREL }(M)_{m}^{\text {PublicEquity }}}{\text { PublicEquity }}$
and Lead-EQUITYREL $(M)_{m}$

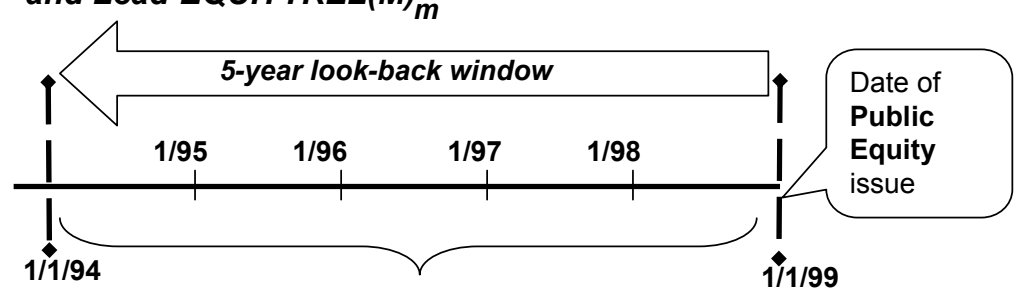

Illustrations:

- Search if bank $m$ lead bank on any loans during this period. If $m$ was the lead bank on any loan, then LOANREL(Dummy) ${ }_{m}^{\text {PublicEquity }}=1$

- Search if bank $m$ lead underwriter on any public debt issue during this period. If $m$ was the lead underwriter on any debt issue, then Lead-DEBTREL(Dummy) $\underset{m}{\text { PublicEquity }=1}$

- Search if bank $m$ lead underwriter on any public equity issue during this period. If $m$ was the lead underwriter on any equity issue, then Lead-EQUITYREL(Dummy) $\underset{m}{\stackrel{P}{\text { PublicEquity }}=1}$ 